


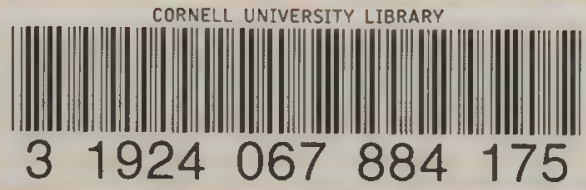

DATE DUE

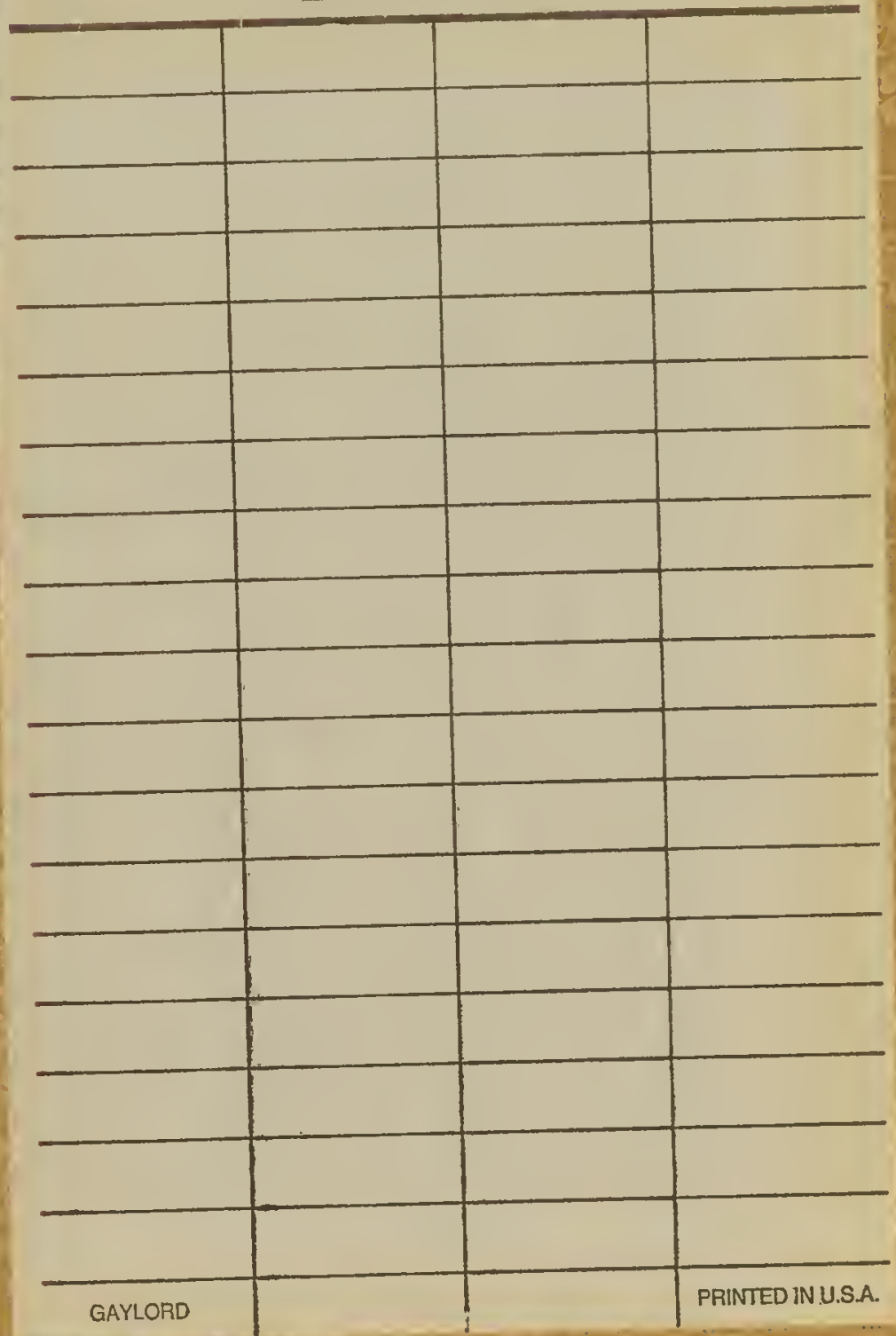





\section{THE LANGUAGE OF FLOWERS}






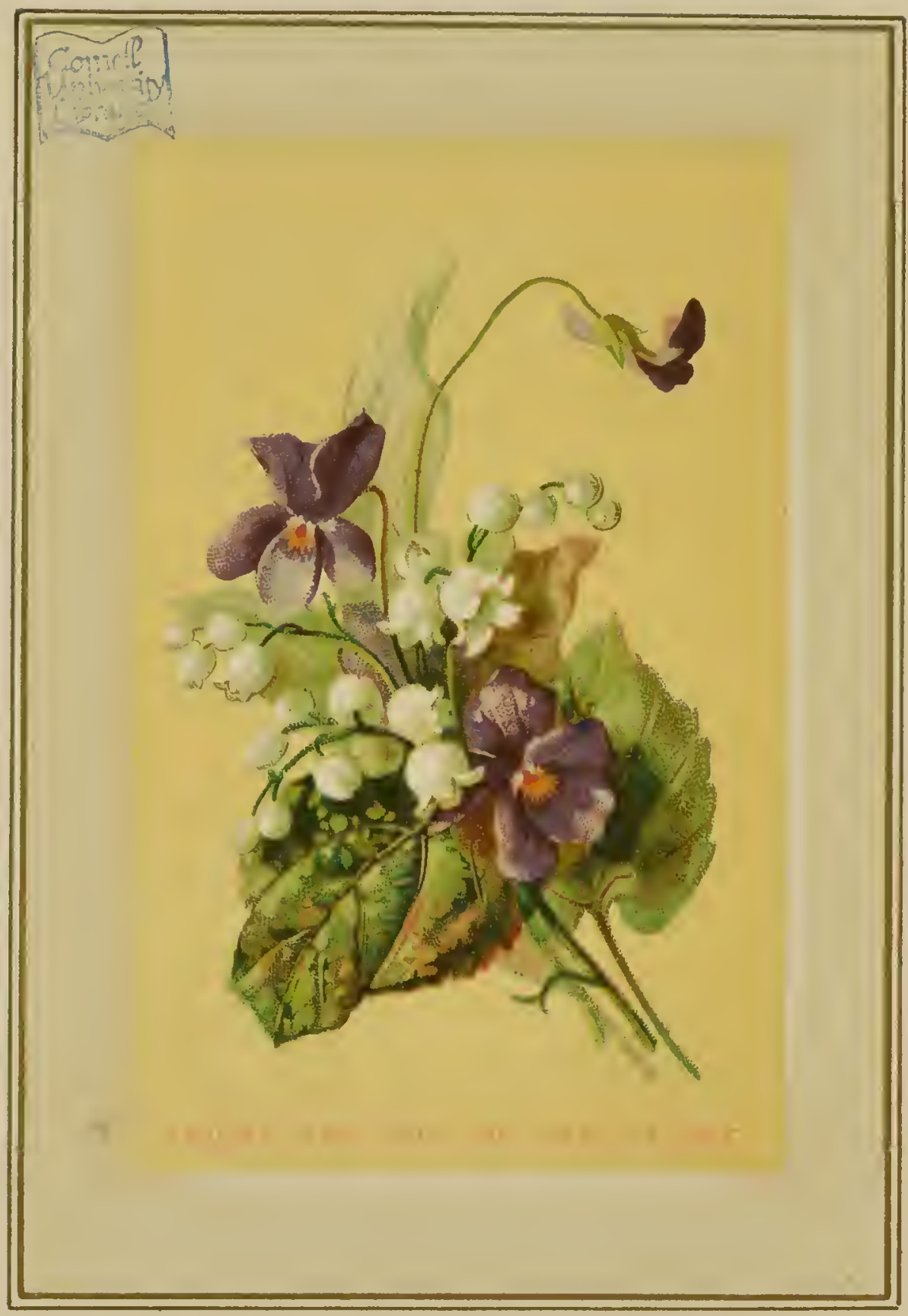




\section{THE}

\section{LANGUAGE OF FLOWERS}

INCLUDING

\section{FLORAL POETRY}

WITH ORIGINAL ILLUSTRATIONS

PRINTED IN COLOURS

"Love's language may be talked with these;

To work out choicest sentences,

No blossoms can be meeter;

And, such being used in Eastern bowers,

Young maids may wonder if the flowers

Or meanings be the sweeter."

\section{LONDON \\ FREDERICK WARNE AND CO. \\ AND NEW YORK}




$$
\begin{aligned}
& \text { VAULT } \\
& \text { RN } \\
& 6110 \\
& F 6 \\
& 134 \\
& 1878
\end{aligned}
$$




\section{PREFACE.}

THIS little volume contains the Language of Flowers, their mythology and symbolism; some hints with regard to their practical utility; selections from the poetry inspired by them; and Floral Dialogues. A game for home is also suggested, to be played with these lovely gifts of Nature. Thus, it is hoped, that alike in sunshine and shade-when June's red roses delight us, or "rain and wind beat dark December"-our readers may enjoy a perennial Bouquet. 



\section{CONTENTS.}

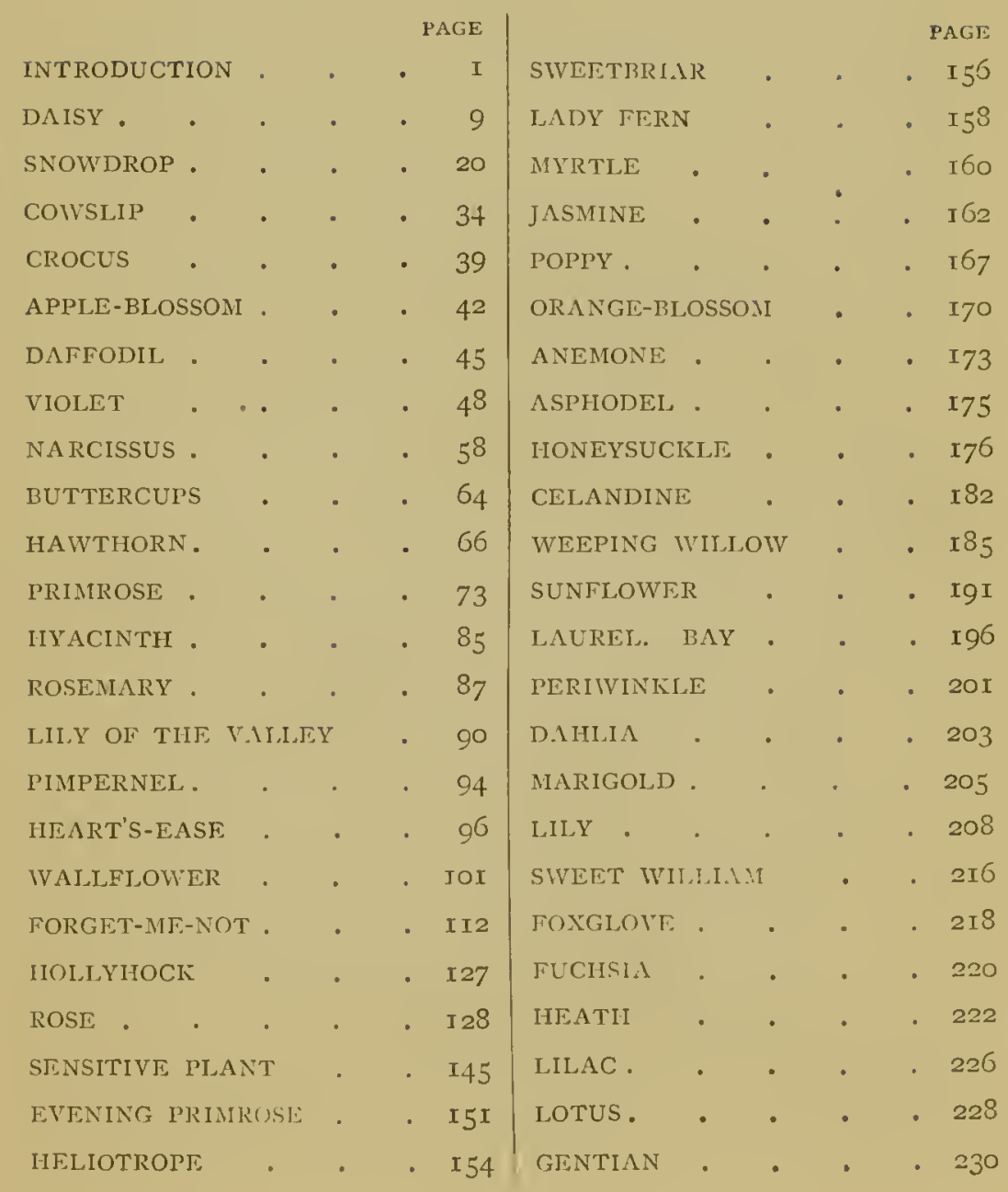


viii

\section{CONTENTS.}

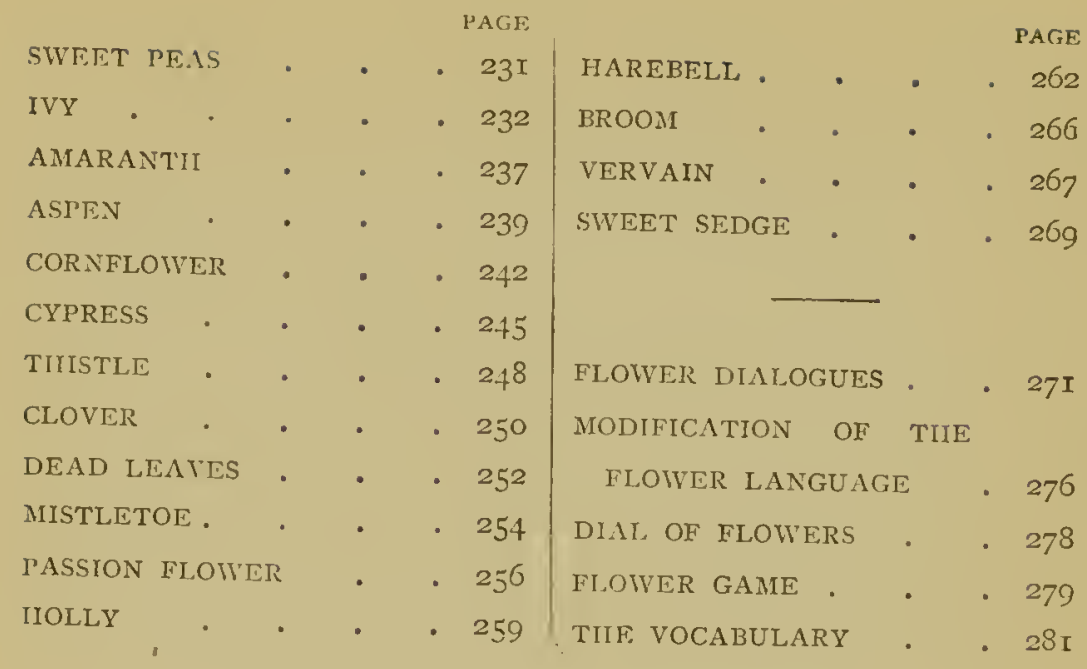




\section{THE}

\section{LANGUAGE OF FLOWERS.}

\section{INTRODUCTION.}

HE most charming of all gifts is one of flowers.

A Queen may (and we rejoice to say our own beloved Sovereign often does) give them to her subjects; and the poorest subject may offer them to a monarch.

They are the representatives of all times and of all nations; the pledges of all feelings. The infant plays with them, and gains his first idea of beauty from their blossoms; the lover gives them to his beloved; the bride wears them. We offer them to our beloved dead; dynasties are represented by a flower; nations adopt them as their emblems. A leaf is the crown of valour. IVars have been fought, alas! in merry England, under a floral emblem; universal is their hold on human sympathies; universal their language.

The Language and Poetry of Flowers must always be an appropriate gift to the young and sensitive; indeed all ages rejoice in their sweetness and beauty, and all poets have sung their praises. 
Hood, in the following pretty lines, has afforded us an admirable introduction to our little volume :-

"Welcome, dear Ileart, and a most kind good-morrow;

The day is gloomy, but our looks shall shine:Flowers I have none to give thee, but I borrow Their sweetness in a verse to speak for thine.

"Here are red Roses, gathered at thy cheeks,The white were all too happy to look white: For love the Rose, for faith the Lily speaks; It withers in false hands, but here 'tis bright!

"Dost love sweet Hyacinth? Its scented leaf Curls manifold, - all love's delights blow double: 'Tis said this floweret is inscribed with grief,But let that hint of a forgotten trouble.

"I plucked the Primrose at night's dewy noon; Like Hope, it showed its blossoms in the night;'Twas, like Endymion, watching for the Moon! And here are Sunflowers, amorous of light!

: These golden Buttercups are April's seal, The Daisy stars her constellations be: These grew so lowly, I was forced to kneel, Therefore I pluck no Daisies but for thee!

"Here's Daisies for the morn, Primrose for gloom, Pansies and Roses for the noontide hours:A wight once made a dial of their bloom,So may thy life be measured out by flowers!"

Our readers will perceive that the symbolism and language of flowers were not unknown to the poet. Mrs. Browning says truly and charmingly :-

"Love's language may be talked with these;

To work out choicest sentences,

No blossoms can be meeter; And, such being used in Eastern bowers, Young maids may wonder if the flowers Or meanings be the swecter. 
"And such being strewn before a bride,

Her little foot may turn aside, Their longer bloom decreeing,

Unless some voice's whispered sound

Should make her gaze upon the ground

Too earnestly for seeing.

"And such being scattered on a grave, W'hoever mourneth there, may have

A type which seemeth worthy

Of that fair body hid below,

Which bloomed on earth a time ago,

Then perished as the earthy.

"And such being wreathed for worldly feasi,

Across the brimming cup some guest

Their rainbow colours viewing,

May feel them, with a silent start,

The covenant his childish heart

With Nature made,-renewing."

And I,eigh Hunt playfully declares :-

"An exquisite invention this,

Worthy of love's most honied kiss,

This art of writing billet doux

In buds and odours, and bright hues;

In saying all one feels and thinks

In clever daffodils and pinks,

Uttering (as well as silence may)

The sweetest words the sweetest way:

How fit, too, for the lady's bosom,

The place where billet doux repose 'em.

"How charming in some rural spot,

Combining love with garden plot,

$\Lambda$ t once to cultivate one's flowers,

And one's epistolary powers,

Growing one's own choice words and fancie:

In orange-tubs and beds of pansies ;

One's sighs and passionate declarations

In odorous rhet'ric of carnations ;

Seeing how far one's stocks will reach ;

Taking due care one's flowers of speech

To guard from blight as well as bathos,

And watering every day one's pathos. 
"A letter comes just gathered: we Dote on its tender brilliancy ; Inhale its delicate expression Of balm and per ; and its eonfession Made with as sweet a maiden blush As ever morn bedewed in bush; And then, when we have kissed its wit, And heart, in water putting it, To keep its remarks fresh, go round Our little eloquent plot of ground, And with delighted hands compose Our answer, all of lily and rose, Of tuberose and of violet, And little darling (mignonette), And gratitude and polyanthus, And flowers that say, "Felt never man thus !"

How the flowers may be made to hold a conversation Christine Pire tells us in the following dialogue :-

THE LOVER.

"I give to thee the Autumn rose, Let it say how dear thou art; All my lips dare not disclose, Let it whisper to thy heart ; How love draws my soul to thee, Without language thou may'st see.

THE LADY.

"I give to thee the aspen-leafTis to show I tremble still When I muse on all the grief Love ean eause, if false or ill ; How, too, many have believed, Trusted long, and being deeeived.

\section{LOVER.}

"I give to thee a faded wreath, Teaching thee, alas! too well, How I spent my latest breath, Seeking all my truth to tell; But thy coldness made me die

Victim of thy cruelty. 
LADY.

"I give to thee the honey-flower, Courteous, best, and bravest knight ;

Fragrant in the summer shower, Shrinking from the sunny light : May it not an emblem prove Of untold, but tender love?"

Flowers also are used for divination. All readers of Göthe will remember Marguerite's flower. The American poet Lowell sends the following pretty lines on the subject, with a pressed flower :-

"This little flower from afar, Hath come from other lands to thine; For once its white and drooping star Could see its shadow in the Rhine.

"Perchance some fair-haired German maid Hath plucked one from the self-same stalk, And numbered over, half afraid, Its petals in her evening walk.

" 'He loves me, loves me not!' she cries; 'He loves me more than earth or heaven ' And then glad tears have filled her eyes To find the number was uneven.

"And thou must count its petals well, Because it is a gift from me : And the last one of all shall tell Something I've often told to thee.

"But here at home, where we were born Thou wilt find flowers just as true, Down-bending every Summer morn With freshness of New England dew.

"For Nature, ever kind to love, Hath granted them the same sweet tongue, Whether with German skies above, Or here our granite rocks among."

There is another mode, resembling the Scottish and 
English superstitions on Hallowe'en and St. Agnes' Eve, by which maidens in Germany seek to dive into futurity. It is by the St. John's Wort. The story is prettily told in these lines, which we transcribe from the "Flora Symbolica :"-

"The young maid stole through the cottage door, And blushed as she sought the plant of power;

' Thou silver glow worm, $O$ lend me thy light, I must gather the mystic St. John's-wort to-night ;

The wonderful herb, whose leaf will decide

If the coming year shall malke me a bride !'

And the glowworm came

With its silvery flame,

And sparkled and shone

'Thro' the night of St. John;

And soon as the young maid her love-knot tied,

"With noiseless tread

To her chamber she sped,

Where the spectral moon her white beams shed.

'Bloom here, bloom here, thou plant of power,

To deck the young bride in her bridal hour ?'

But it drooped its head, that plant of power,

And died the mute death of the voiceless flower;

And a withered wreath on the ground it lay,

More meet for a burial than bridal day.

And when a year was past away,

All pale on her bier the young maid lay !

And the glowworm came

With its silvery flame,

And sparkled and shone

Thro' the night of St. Jonn ;

And they closed the cold grave o'er the maid's cold clay."

Games also are made of flowers. In fact, time would fail to tell of all the joy and beauty which these sweet creations bestow upon humanity. Through life to death they cheer us; and it is not one of the least of our anticipated joys hereafter that we shall dwell amid those flowers of Paradise, of which these earthly blossoms are but faint shadows. 
And in these days of utility, when a thing is nothing it not useful, we must remind our readers that the vegetable and floral world holds in it the secret of health to a greater degree, we believe, than is yet dreamt of in our philosophy. They make the air we breathe pure and lifegiving. It is a known fact that Lavender and many other flowers supply ozone to the atmosphere; the humble Lichen was one of the ingredients in the dye of imperial purple, for which 'lyre and Sidon were famous; and the search for it brought Phœnician commerce to the Irish shores in the days of Ptolemy. Another Lichen, the Rocella tinctoria, afforded the first dye for British broad cloths. The Mosses shared in this utility.

The Dandelion affords the Taraxacum, a valuable medicine. The tubers called "Lords and ladies," dear to babyhood, furnish a species of arrowroot. The tubers of the Orchis afford a similar preparation called salep, a favourite posset with our great-grandmothers.

The Rock Samphire bestows a pickle on our tables. The Red rose leaf is an admirable tonic; the Lily leai heals a cut. Chamomile is a tonic. Cowslip affords a wine and a pudding, besides an infant's ball ; the Lesser Celandine is still used in medicine for the relief of a painful disease; and who is ignorant of the blessed soothing powers of the Poppy and Henbane? Greek mythology has left a floral record; and beautiful blossoms are also memorials of our country's past: the Mistletoe, Vervain, and St. John's Wort recal Druidic rites of ancient Britain. Julius Cæsar has recorded the beauty of our hedge roses; the grandest dynasty of our kings was named from a plant (the Broom, or Plantagenista); York and Lancaster fought under a white and red rose. The banished Henry Bolingbroke had previously adopted as 
his badge the "Forget-me-not." The Hawthorn was assumed by the Tudors as their especial insignia, in remembrance of the crown which they gained at Bosworth being found hanging on a Thorn.

Thus we may give with a bouquet memories of mythology, history, usefulness, beauty, and fragrance; and in modern times we have added to the ancient claims of flowers that of language - a gift bestowed on them by the East, and transplanted thence by one of the most gifted of Englishwomen, Lady Mary Wortley Montagu.

For this work, we have availed ourselves of all the goodly heritage of flower-land. And with these few lines of introduction, we leave them to their more worthy
chroniclers-the Poets. 


\section{$D A I S Y$.}

\section{(Innocence.)}

"Whose white investments figure innocence."-SHAKSPEARE.

$\mathrm{HE}$ flower which, next to the rose, appears to have received the most attention from the poets is the Daisy.

Formerly it was termed the "e'e of daie," and under that name Chaucer speaks of it.

According to the classic account, this little flower owed its origin to Belides, one of the dryads, the nymphs who presided over woodlands. It is fabled that whilst this damsel was dancing with her favoured suitor, Ephigeus, she attracted the attention of Vertumnus, the guardian deity of orchards : and it was in order to shelter her from his pursuit that she was transformed into Ballis, or the daisy-the "day's eye," as our old poets call it - the flower of faithful love, which opens and closes with the sun.

It is called in French la Murguerite, or pearl.

The unhappy Margaret of Anjou chose it as her device; and when she reigned a beauty and crowned queen, the nobles of England wore wreaths of it, or had it embroidered on their robes. 
Marguerite de Valois, the friend of Erasmus and Calvin-the Marguerite of Marguerites-also aciopted this flower as her device; and it was more appropriate certainly to the princess who withdrew from the glitter of courts to study her Bible than to the ambitious Lancastrian queen of England.

\section{THE DAISIE.}

\section{CHAUCER.}

DAISIE of light ! very ground of comfort! The sunnis doughtir ye light, as I rede, For when he westrith, farwell your disport; By your nature anone, right for pure drede Of the rude Night, that with his boistous wede Of derkenesse shadowith our hemisphere, Then closin ye, my liv'is ladie dere.

Daunying the daie unto his kind resort, And Phœbus your fethir with his stremes rede Adurneth the morrowe, consuming the sort Of mistie cloudes, that wouldin ovirlede 'True humble hertis with ther mistie hede, Nere comfort adaies, when your eyin clere Disclose and sprede, my liv'is ladie dere.

Je vouldray; but the grete God disposeth And makith casuell by His providence Soche thing as mannis frele wit purposeth, All for the best, if that your conscience 
Not grutche it, but in humble pacience It receve; for God saith withoutin fable, A faithfull herte evir is acceptable.

From "A Godely Balade."

\section{TO THE DAISY.}

WORDSWORTH.

BRIGHT flower! whose home is everywhere, Bold in maternal Nature's care, And all the long year through the heir Of joy or sorrow ;

Methinks that there abides in thee Some concord with humanity, Given to no other flower I see The forest thorough!

Is it that man is soon deprest?

A thoughtless thing? who, once unblest, Does little on his memory rest,

Or on his reason, And thou wouldst teach him how to find A shelter under every wind,

A hope for times that are unkind, And every season?

'Thou wander'st the wide world about, Uncheck'd by pride or scrupulous doubt, With friends to greet thee, or without, Yet pleased and willing; 
Meek, yielding to the occasion's call, And all things suffering from all, Thy function apostolical In peace fulfilling.

\section{TO THE DAISY.}

WORDSWORTH.

IN youth from rock to rock I went, From hill to hill, in discontent Of pleasure high and turbulent, Most pleased when most uneasy; But now my own delights I make, My thirst at every rill can slake, And Nature's love of thee partake, Her much-loved daisy!

Thee Winter in the garland wears That thinly decks his few grey hairs; Spring parts the clouds with softest airs, That she may sun thee;

Whole summer-fields are thine by right; And Autumn, melancholy wight! Doth in thy crimson head delight, When rains are on thee.

Be violets in their secret mews The flowers the wanton zephyrs choose; Proud be the rose, with rains and dews Her head impearling ; 
Thou liv'st with less ambitious aim,

Yet hast not gone without thy flame;

Thou art indeed, by many a claim,

The poet's darling.

If to a rock from rain we fly,

Or some bright day of April sky, Imprisoned by hot sunshine lie

Near the green holly,

And wearily at length should fare:

He needs but look about, and therc

Thou art !-a friend at hand to scare

His melancholy.

A hundred times, by rock or bower, Ere thus I have lain couched an hour, Have I derived from thy sweet power

Some apprehension;

Some steady love; some brief delight;

Some memory that had taken flight;

Some chime of fancy, wrong or right ;

Or strong invention.

If stately passions in me burn, And one chance look to thee should tum.

I drink out of an humble urn

A lowlier pleasure;

The homely sympathy that heeds

The common lire, our nature breeds;

A wisdom fitted to the needs

Of hearts at leisure. 
Fresh smitten by thy morning ray,

When thou art up, alert and gay,

Then, cheerful flower ! my spirits play

With kindred gladness :

And when at dusk, by dews opprest,

Thou sink'st, the image of thy rest

Hath often eased my pensive breast

Of careful sadness.

And all day long I number yet, All seasons through, another debt, Which I, wherever thou art met,

To thee am owing;

An instinct call it, a blind sense-

A happy, genial influence,

Coming one knows not how, nor whence,

Nor whither going.

Child of the year! that round dost run Thy pleasant course,-when day's begun, As ready to salute the sun

As lark or leveret,

Thy long-lost praise thou shalt regain ;

Nor be less dear to future men

Than in old time ; thou not in vain Art Nature's favourite. 


\section{THE DAISY.}

\section{MASON GOOD.}

Not worlds on worlds in phalanx deep,

Need we to prove that God is here;

The daisy, fresh from winter's sleep,

Tells of His hand in lines as clear.

For who but He who arched the skies,

And poured the day-spring's living flood,

Wondrous alike in all $\mathrm{He}$ tries,

Could rear the daisy's purple bud;

Mould its green cup, its wiry stem,

Its fringèd border nicely spin,

And cut the gold-embossed gem

That, set in silver, gleams within;

And fling it, unrestrained and free,

O'er hill, and dale, and desert sod,

That man, where'er he walks, may see,

At every step the stamp of God:

\section{THE DAISY.}

\section{CLARE.}

TRAMPLED under foot,

The daisy lives, and strikes its little root

Into the lap of Time; centuries may come And pass away into the silent tomb, And still the child, hid in the womb of Time, Shall smile and pluck them; when this simple rhyme 
Shall be forgotten, like a church-yard stone,

Or lingering lie, unnoticed and alone,

When eighteen hundred years, our common date,

Grow many thousands in their marching state, Ay, still the child, with pleasure in his eye, Shall cry, "the daisy"-A familiar cryAnd run to pluck it, in the self-same state; And, like a child himseli, when all was new, Might smile with wonder, and take notice too; Its little golden bosom filled with snow, Might win e'en Eve to stoop adown and show Her partner, Adam, in the silken grass, The little gem, that smiled where pleasure was. And, loving Eve, from Eden followed ill And bloomed with sorrow,-and lives smiling still, As once in Eden, under Heaven's breath, So now on Earth, and on the lap of death, It smiles for ever.

\section{TO A MOUNTAIN DAISY.}

ON TURNING ONE DOWN WITH A PLOUGH BURNS.

WEE, modest, crimson-tipped flower, Thou's met me in an evil hour, For I maun crush amang the stoure* Thy slender stem;

To spare thee now is past my powcr, Thou bonnie gem. 
Alas! it's no thy neebor sweet, The bonnie lark, companion meet, Bending thee 'mang the dewy weet, Wi' speckled breast, When upward springing, blithe to greet The purpling east.

Cauld blew the bitter, biting north Upon thy early, humble birth;

Yet cheerfully thou glinted $\uparrow$ forth Amid the storm,

Scarce reared above the parent earth Thy tender form.

The flaunting flowers our gardens yield, High sheltering woods and wa's $\ddagger$ maun shield, But thou, beneath the random bield\$

O' clod or stane,

Adorns the histie stibble-field,

Unseen, alane.

There, in thy scanty mantle clad, Thy snawie bosom sunward spread, Thou lifts thy unassuming head In humble guise;

But now the share uptears thy bed, And low thou lies!

Such fate to suffering worth is given, Who lang with wants and woes has striven. By human pride or cunning driven 'To misery's brink,

- Weet, rain, wetness.

t Wa's, walls.

+ Glinted, peeped.

$\S$ Random bicld, casual shelter. 
Till, wrenched of every stay but Heaver, He ruined, sink !

Even thou, who mourn'st the daisy's fate, That fate is thine-no distant date;

Stern Ruin's ploughshare drives elate

Full on thy bloom, Till, crushed beneath the furrow's weight, Shall be thy doom!

\section{WHITE DAISY.}

THOMAS HOOD.

AH ! happy forest glades,

And murmurous green arcades,

Ye myriad songsters on the boughs above,

When here White Daisy strays,

Greet her with joyous lays,

And in your madrigals reveal my love.

Woo her, fond turtle dove,

Sweet nightingale complain,

Ask for my heart again.

While all the warblers of the air,

Combine to sing the praises of my fair,

With pipes and trills and wanderings mazy, Singing-all Nature loves thee, Sweet White Daisy.

Where her small foot is set, Springs the sweet violet, And pink-lipped daisies kiss her dress's hem, Marking with tiny flowers Her footprints in the bowers, For joy that she should take her name from then ; 
She needs no diadem, Because her golden hair Is so surpassing fair, No crown can match its lustre fine. She comes! Oh birds, to hail your queen combine, With pipes and trills and wanderings mazy, Singing-all Nature loves thee, Queen White Daisy.

\section{THE DAISY AT THE DELUGE.}

BEDDOES.

THE daisy in Noah's meadow, On which the foremost drop of rain fell warm And soft at evening; so the little flower Wrapped up its leaves, and shut the treacherous water Close to the golden welcome of its breastDelighting in the touch of that which led The shower of oceans, in whose billowy drops; Tritons and lions of the sea were warring.

\section{DAISIES.}

ELLA INGRAM.

Daisies they live in deathless rhymes 'Mid songs by poets given; Nor blight nor winter mar their chimes, Merrily live for future times Fadeless as flower in heaven. 


\title{
SNOWDROP;
}

OR,

FAIR MAID OF FEBRUARY.

(Friend in Need-Hope.)

\begin{abstract}
TE snowdrop is dedicated to the Virgin Mary; and tradition asserts that it blooms on the second of February, or Candlemas Day-the day kept in celebration of the Holy Virgin taking the Child Jesus to the Jewish Temple, and there presenting the appointed offering of two turtle doves.
\end{abstract}

\section{THE SNOWDROP.}

WESTWOOD.

THE snowdrop is the herald of the flowers, Sent with its small white flag of truce to plead For its beleaguered brethren : suppliantly, It prays stern winter to withdraw his troop Of winds and blustering storms; and having won A smile of promise from his pitying face, Returns to tell the issue of its errand, To the expectant host. 


\section{THE SNOWDROP.}

WORDSWORTH.

Lone flower, hemmed in with snows, and white as they

But hardier far, once more I see thee bend

Thy forehead, as if fearful to offend,

Like an unbidden guest. Though day by day

Storms, sallying from the mountain tops, waylay

The rising sun, and on the plains descend,

Yet art thou welcome, welcome as a friend

Whose zeal outruns his promise! Blue-eyed May

Shall soon behold this border thickly set

With bright jonquils, their odours lavishing

On the soft west wind and his frolic peers;

Nor will I then thy modest grace forget,

Chaste snowdrop, venturous harbinger of Spring,

And pensive monitor of fleeting years!

\section{ORIGIN OF THE SNOWDROP.}

G. W.

No fading flowers in Eden grew, Nor autumn's withering spread Anong the trees a browner hue, To show the leaves were dead;

But through the groves and shady delis,

Waving their bright immortal bells

Were amaranths and asphodels,

Undying in a place that knew

A golden age the whole year through. 
But when the angels' fiery bands,

Guarding the eastern gate,

Told of a broken law's commands,

And agonies that came too late;--With "longing, lingering" wish to stay, And many a fond but vain delay, That could not wile her grief away, Eve wandered aimless o'er a world On which the wrath of God was hurled.

Then came the spring's capricious smile, And summer sunlight warmed the air, And autumn's riches served awhile,

To hide the curse that lingered there, Till o'er the once untroubled sky Quick-driven clouds began to fly, And moaning zephyrs ceased to sigh, When winter's storms in fury burst Upon a world indeed accurst.

And when at last the driving snow

A strange, ill-omened sight, Came whitening all the plains below,

To trembling Eve it seemed-aftright, With shivering cold and terror bowed, As if each fleecy vapour cloud Were falling as a snowy shroud To form a close enwrapping pall For earth's untimeous funeral.

Then all her faith and gladness fled, And nothing left but black despair, Eve madly wished she had been dead, Or never born a pilgrim there; 
But, as she wept, an angel bent

His way adown the firmament, And, on a task of mercy sent, He raised her up, and bade her cheer Her drooping heart, and banish fear:

And catching, as he gently spake,

A flake of falling snow,

$\mathrm{He}$ breathed on it, and bade it take

A form, and bud and blow;

And, ere the flake had reached the earth,

Eve smiled upon the beauteous birth, That seemed amid the general dearth Of living things, a greater prize Than ail her flowers in Paradise.

"This is an earnest, Eve, to thee," The glorious angel said, "That sun and summer soon shall be; And though the leaves seem dead, Yet once again the smiling spring, With wooing winds shall swiftly bring New life to every sleeping thing: Until they wake and make the scene Look fresh again and gaily green."

The angel's mission being ended,

Up to heaven he flew,

But where he first descended,

And where he bade the earth adieu,

A ring of snowdrops formed a posy

Of pallid flowers, whose leaves, unrosy,

Waved like a winged argosy,-

Whose climbing masts, above the sea,

Spread fluttering sail and streamer free. 
And thus the snowdrop, like the bow

That spans the cloudy sky,

Becomes a symbol whence we know

That brighter days are nigh ;

That circling seasons, in a race

That knows no lagging lingering pace,

Shall each the other nimbly chase

Till Time's departing final day

Sweep snowdrops and the world away!

\section{TO A SNOWDROP.}

LANGHORNE.

Poets still, in graceful numbers, May the glowing roses choose;

But the snowdrop's simple beauty Better suits an humble muse.

Earliest bud that decks the garden, Fairest of the fragrant race,

Firstborn child of Vernal Flora

Seeking mild thy lowly place;

Though no warm or murmuring zephyr Fan thy leaves with balmy wing,

Pleased we hail thee, spotless blossom, Herald of the infant Spring.

Through the cold and cheerless season

Soft thy tender form expands,

Safe in unaspiring graces,

Foremost of the blooming bands. 
White-robed flower, in lonely beauty,

Rising from a wintry bed;

Chilling winds, and blasts ungenial,

Rudely threatening round thy head.

Silvery bud, thy pensile foliage

Seems the angry blasts to fear;

Yet secure, thy tender texture

Ornaments the rising year.

No warm tints, or vivid colouring,

Paint thy bells with gaudy pride;

Mildly charmed, we seek thy fragrance,

Where no thorns, insidious hide.

'Tis not thine, with flaunting beauty

To attract the roving sight;

Nature, from her varied wardrobe,

Chose thy vest of purest white.

White, as falls the fleecy shower,

Thy soft form in sweetness grows;

Not more fair the valley's treasure,

Not more sweet her lily blows.

Drooping harbinger of Flora, Simply are thy blossoms drest;

Artless as the gentle virtues

Mansioned in the blameless breast.

When to pure and timid virtue

Friendship twines a votive wreath,

O'er the fair selected garland

Thou thy perfume soft shall breathe. 


\section{THE SNOWDROP.}

MRS. HOWITT.

THE snowdrop! 'Tis an English flower, And grows beneath our garden trees; For every heart it has a dower, And old and dear remembrances ! All look upon it, and straightway Recall their youth like yesterday, Their sunny years when forth they went, Wandering in measureless content; Their little plot of garden ground, The mossy orchard's quiet bound; Their father's house so free from care, And the familiar faces there;

The household voices kind and sweet, That knew no feigning-hushed and gone! The mother that was sure to greet

Their coming with a welcome tone; The brothers that were children then, Now anxious, toiling, thoughtful men; And the kind sister whose glad mirth Was like a sunshine on the earthThese come back to the soul supine, Flower of the spring, at look of thine: And thou among the dimmed and gone, Art an unaltered thing alone!

Unchanged-unchanged-the very flower

That grew in Eden droopinglyAnd now beside the peasant's door Awakes his little children's glee, Even as it filled his heart with joy Beside his mother's door, a boy !- 
The same-and to his heart it brings The freshness of those vanished springs!

Bloom then, fair flower, in sun and shade, For deep thought in thy cup is laid; And careless children, in their glee, A sacred memory make of thee!

\section{TO THE SNOWDROP.}

KEBLE.

Tноч first-born of the year's delight, Pride of the dewy glade,

In vernal green and virgin white,

Thy vestal robes arrayed:

'Tis not because thy drooping form Sinks grateful on its nest, When chilly shades from gathering storm Affright thy tender breast;

Nor from yon river islet wild, Beneath the willow spray, Where like the ringlets of a child, Thou wear'st thy circle gay;

'Tis not for these I love thee dear, Thy shy averted smiles To fancy bode a joyous year, One of life's fairy isles. 
They twinkle to the wintry moon, And cheer the ungenial day, And tell us all will glisten soon, As green and bright as they.

Is there a heart that loves the spring, Their witness can refuse?

Yet mortals doubt when angels bring

From Heaven their Easter news :

When holy maids and matrons speak

Of Christ's forsaken bed, And voices, that forbid to seek

The living 'mid the dead;

And when they say, "Turn, wandering heart,

Thy Lord is risen indeed, Let pleasure go, put care apart, And to His presence speed ;"

We smile in scorn; and yet we know They early sought the tomb, Their hearts that now so freshly glow, Lost in desponding gloom.

They who have sought, nor hope to finc.

Wear not so bright a glance: They who have won their earthly mind, Less reverently advance.

But where, in gentle spirits, fear And joy so duly meet, These sure have seen the angels near. And kissed the Saviour's feet. 
Nor let the pastor's thankful eye

Their faltering tale disdain, As on their lowly couch they lie,

Prisoners of want and pain.

O guide us, when our faithless hearts

From thee would start aloof,

Where patience her sweet skill imparts

Beneath some cottage roof:

Revive our drooping fires, to burn

High as her anthems soar, And of our scholars let us learn

Our own forgotten lore.

\section{THE SNOWDROP.}

MRS. ROBINSON.

THE Snowdrop, Winter's timid child, Awakes to life, bedewed with tears, And flings around its fragrance mild; And, where no rival flowerets bloom Amidst the bare and chilling gloom,

A beauteous gem appears. $*$ * * *

Where'er I find thee, gentle flower,

Thou still art sweet and dear to me!

For I have known the cheerless hour, Have seen the sunbeams cold and palc.

Have felt the chilling wintry gale, And wept and shrunk like thee. 


\section{THE SNOWDROP.}

CHARLOTTE SMITH.

LIKE pendant flakes of vegetating snow, The early herald of the infant year, Ere yet the adventurous crocus dares to blow, Beneath the orchard boughs thy buds appear. While still the cold north-east ungenial lowers, And scarce the hazel in the leafless copse Or shallows show their downy powdered flowers, The grass is spangled with thy silver drops. Yet when those pallid blossoms shall give place

To countless tribes of richer hue and scent, Summer's gay blooms, and autumn's yellow race, I shall thy pale inodorous bells lament.

\section{SNOWDROPS.}

"DOVE ON THE CROSS."

My snowdrops, oh, my snowdrops !

How gaily every spring

They covered all our mossy banks

With many a fairy ring!

How delicately beautiful

Their little blossoms were,

Like tiny spirits hovering

Upon the chilly air.

My snowdrops, oh, my snowdrols !

I shall never without pain

See your little fragile blossoms

In the early spring again; 
For my only one, my loved one,

A fragile thing like you,

Both came to me and left me

In the spring as snowdrops do.

Like the crimson light of sunset

Streaming through a wreath of snow,

So soft upon her pallid cheek

The hectic fever's glow.

As fading snowdrops gently sink

Upon the cold earth's breast,

So gently sank my holy child

To her eternal rest.

My only one, my loved one,

I shall see her yet again,

When I, too, am transplanted

From this world of grief and pain.

Her snowdrops, oh, her snowdrops!

Shall be ever dear to me-

I will cherish them as emblems

Of her immortality.

\section{THE SNOWDROP.}

As Hope, with bowed head, silent stood,

And on her golden anchor leant,

Watching below the angry flood,

While Winter, 'mid the dreariment

Half-buried in the drifted snow,

Lay sleeping on the frozen ground, 
Not heeding how the wind did blow,

Bitter and bleak on all around: She gazed on Spring, who at her feet Was looking at the snow and sleet.

Spring sighed, and through the driving gale Her warm breath caught the falling snow, And from the flakes a flower as pale Did into spotless whiteness blow; Hope, smiling, saw the blossom fall,

And watched its root strike in the earth,"I will that flower the Snowdrop call," Said Hope, "in memory of its birth; And through all ages it shall be In reverence held, for love of me."

"And ever from my hidden bowers," Said Spring, "it first of all shall go, And be the herald of the flowers,

To warn away the sheeted snow: Its mission done, then by thy side All summer long it shall remain. While other flowers I scatter wide O'er every hill, and wood, and plain, This shall return, and ever be A sweet companion, Hope, for thee."

Hope stooped and kissed her sister Spring, And said, "For hours, when thou art gone, I'm left alone without a thing That I can fix my heart upon; 'Twill cheer me many a lonely hour, And in the future I shall see 
Those who would sink, raised by that flower,

They'll look on it, then think of thee;

And many a weary heart shall sing,

The Snowdrop bringeth Hope and Spring.

\section{S N O W D R O P S.}

\section{SONNET.}

WORDSWORTH.

WHEN haughty expectations prostrate lie, And grandeur crouches like a guilty thing, Oft shall the lowly weak, till nature bring Mature release, in fair society

Survive, and Fortune's utmost anger try;

Like these frail snowdrops that together cling And nod their helmets, smitten by the wing Of many a furious whirl-blast sweeping by. Observe the faithful flowers! if small to great May lead the thoughts, thus struggling used to stand The Emathian phalanx, nobly obstinate; And so the bright immortal 'Theban band Whom onset, fiercely urged at Jove's command, Might overwhelm but could not separate. 


\section{THE COWSLIP. \\ (Pensiveness-Winning Youthful Grace.)}

5. HE "pretty Mullein," as it is called, is one of the 20. sweetest of our meadow flowers. The yellow oxlip is larger, and not quite so common.

Cowslip wine is pleasant, and said to be slightly narcotic.

Shakspeare, speaking of the Fairy Queen, says :

"The cowslips tall her pensioners be ;

In their gold coats spots we see;

Those be rubies, fairy favours, -

In those freckles live their savours;

I must go seek some dewdrops here,

And hang a pearl in every cowslip's ear."

Milton, in his masque of "Comus," has given an exquisite song to Sabrina, in which the airy tread of that goddess "o'er the cowslip's velvet head" is most delicately expressed :

"By the rushy, fringcd bank,

Whcre grow the willow and the osier dank,

My sliding chariot stays;

Thick set with agate and the azure sheen

Of turkis blue and emerald green,

That in the channel strays;

Whilst from off the waters fleet,

Thus I set my printless feet, 
O'er the cowslip's velvet head,

That bends not as I tread.

Gentle swain, at thy request I am here."

These flowers furnish an abundant supply of honey to the bee; for

" Rich in vegetable gold, From calyx pale the freckled cowslip born, Receives in amber cups the fragrant dews of morn."

\section{THE COWSLIP.}

\section{MIRS. SIGOURNEY.}

Good neighbour cowslip, I have seen the bee Whispering to you, and have been told he stays

Quite long and late amid your golden cells. Is it not business that he comes uponMatter of fact? He never wastes an hour. Know you that he's a subtle financier, And shows some gain for every day he spends? Oh! learn from him the priceless worth of time, Thou fair and frail! So shalt thou prove the truth, That he who makes companion of the wise Shall in their wisdom share.

\section{THE COWSLIP.}

ANON.

UNFolding to the breeze of May, The cowslip greets the vernal ray:

The topaz and the ruby gem Her blossoms' simple diadem; 
And as the dewdrops gently fall, They tip with pearls her coronal.

In princely halls, and courts of kings.

Its lustrous ray the diamond fings, Yet few of those who see its beam Amid the torches' dazzling gleam, As bright as though a meteor shone, Can call the costly prize their own.

But gems of every form and hue Are glittering here in morning dew ; Jewels that all alike may share As freely as the common air; No niggard hand, no jealous eye, Protects them from the passer-by.

Man to his brother shuts his heart, And science acts a miser's part; But Nature with a liberal hand Flings wide her stores o'er sea and land If gold she give, not single grains Are scattered far across the plains; But lo, the desert streanis are rolled O'er precious beds of virgin gold. If flowers she offer, wreaths are given As countless as the stars of heaven! Or music,-'tis no feeble note She bids along the valleys float, Ten thousand nameless melodies In one full chorus swell the breeze. 
$\mathrm{Oh}, \mathrm{Art}$ is but a scanty rill

That genial seasons scarcely fill,

But Nature needs no tide's return

To fill afresh her flowing urn :

She gathers all her rich supplies

Where never-failing fountains rise.

\section{O W S L I P S.}

MARY HOWITT.

$\mathrm{OH}$ ! fragrant dwellers of the lea,

When first the wildwood rings

With each sound of vernal minstrelsy,

When fresh the green grass springs!

What can the blessed spring restore

More gladdening than your charms,

Bringing the memory once more

Of lovely fields and farms!

Of thickets, breezes, birds, and flowers ;

Of life's unfolding prime;

Of thoughts as cloudless as the hours;

Of souls without a crime.

Oh! blessed, blessed do ye seem,

For, even now, I turned

With soul athirst for wood and stream,

From streets that glared and burned.

From the hot town, where mortal care

His crowded fold doth pen;

Where stagnates the polluted air

In many a sultry den. 
And are ye here? and are ye here?

Drinking the dew like wine, 'Midst living gales and waters clear, And heaven's unstinted shine.

I care not that your little life Will quickly have run through, And the sward with summer children rife Keep not a trace of you.

For again, again, on dewy plain,

I trust to see you rise, When spring renews the wildwood strain, And bluer gleam the skies.

Again, again, when many springs

Upon my grave shall shine, Here shall you speak of vanished things

To living hearts of mine.

\section{THE COIVSLIP.}

MISS LANDON.

THE cowslip, that bending With its golden bells, Of each glad hour's ending With a sweet chime tells. 


\section{CROCUS. \\ (Cheerfulness-Hope.)}

9.9CORDING to some authors, these bright little flowers, which

"Come before the swallow dares, And take the winds of March with beauty,"

derive their name from a Greek word signifying thread, from the fact of their thread or filament being in such request for saffron dye.

The Greeks fabled that Crocu, a beautiful youth, was transformed into this flower; as his lady-love, Smilax, was at the same time into a yew-tree.

It is in England consecrated to St. Valentine.

Bees are excessively fond of the crocus; and Moore thus alludes to this fact in "Lalla Rookh" :

$$
\text { "The busiest hive }
$$

On Bela's hills is less alive,

When saffron-beds are full in flower,

Than looked the valley in that hour."

Mrs. Howitt says of the purple crocus :

"Like lilac flame its colour glows,

Tender and yet so clearly bright, That all for miles and miles about The splendid meadow shineth out, And far-off village children shout

To see the welcome sight." 


\section{TO A CROCUS}

BLOOMING BENEATH A WALLFLOWER.

BARTON.

WELCOME, wild harbinger of spring !

To this small nook of earth;

Feeling and fancy fondly cling

Round thoughts which owe their birth

To thee, and to the humble spot

Where chance has fixed thy lowly lot.

To thee,-for thy rich golden bloom,

Like heaven's fair bow on high,

Portends, amid surrounding gloom,

That brighter hours draw nigh,

When blossoms of more varied dyes

Shall ope their tints to warmer skies.

Yet not the lily, nor the rose,

Though fairer far they be,

Can more delightful thoughts disclose

Than I derive from thee :

The eye their beauty may prefer;

The heart is thy interpreter!

Methinks in thy fair flower is seen,

By those whose fancies roan,

An emblem of that leaf of green

The faithful dove brought home, When o'er the world of waters dark Were driven the inmates of the ark.

That leaf betokened freedom nigh

To mournful captives there; 
Thy flower foretells a sunnier sky,

And chides the dark despair,

By winter's chilling influence flung

O'er spirits sunk, and nerves unstrung.

And sweetly has kind Nature's hand

Assigned thy dwelling-place

Beneath a flower whose blooms expand With fond congenial grace,

On many a desolated pile,

Brightening decay with beauty's smile.

Thine is the flower of Hope, whose hue

Is bright with coming joy;

The wallflower's that of Faith, too true

For ruin to destroy;-

And where, $\mathrm{O}$ ! where should Hope up-spring

But under Faith's protecting wing.

\section{TO THE CROCUS.}

PATTERSON.

LowLy, sprightly little flower!

Herald of a brighter bloom,

Bursting in a sunny hour

From thy winter tomb.

Hues you bring, bright, gay, and tender:

As it never to decay;

Fleeting in their varied splendour-

Soon, alas! it fades away.

Thus the hopes I long had cherished, Thus the friends I long had known,

One by one, like you, have perished.

Blighted-I must fade alone. 


\section{APPLE-BLOSSOM.}

\section{(Preference.)}

$9 \mathrm{~N}$ the Scandinavian mythology the apple-tree played an important part. In the "Edda," the goddess Iduna is related to have had charge of the apples which had the power of conferring immortality, and which, in consequence of their miraculous property, were especially retained for the gods to eat when they felt themselves growing old. The evil spirit, Loki, carried off Iduna and the wonderful apple-tree, and hid them away in a forest where the deities were unable to find them. The results of this spiteful theft were that every thing went wrong, both in the realms mundane and divineThe gods grew old and infirm, and, becoming enfeebled in mind and body, were no longer able to regulate the affairs of the earth; and mortals, no longer having any one to look after them, fell into evil ways, and became a prey to the evil spirit. Affairs grew worse daily, until the gods, combining the remains of their strength, overcame Loki, and compelled him to restore the stolen apple-tree. The fruit was offered by the Thebans to Hercules. The Druids also highly reverenced this tree. 


\title{
APPLE-BLOSSOMS.
}

\author{
L. E. L.
}

OF all the months that fill the year

Give April's month to me,

For earth and sky are then so filled

With sweet variety!

The apple-blossoms' shower of pearl,

Though blent with rosier hue-

As beautiful as woman's blush,

As evanescent too.

On every bough there is a bud,

In every bud a flower;

But scarcely bud or flower will last

Beyond the present hour.

Now comes a shower cloud o'er the sky,

Then all again sunshine;

Then clouds again, but brightened with

The rainbow's coloured line.

Ay, this, this is the month for me!

I could not love a scene

Where the blue sky was always blue,

'The green earth always green.

\section{TO BLOSSOMS.}

HERRICK.

FAIr pledges of a fruitful tree,

Why do you fall so fast?

Your date is not so past; 
But you may stay here yet awhile, To blush and gently smile,

$$
\text { And go at last. }
$$

What, were ye born to be An hour or half's delight, And so to bid good night? 'Twas pity Nature brought ye forth, Merely to show your worth, And lose you quite.

But you are lovely leaves, where we May read how soon things have Their end, though ne'er so brave: And after they have shown their pride Like you awhile, they glide Into the grave.

\section{TO APPLE BLOSSOMS.}

LOVELy flowers of promise hail! Sweet pale blossoms of the Spring, Tenderest hues of rose and snow To the russet bough you bring.

Beauty full of hope and joy

In your frail, sweet blooms we see; Welcome, then, to sun and shower Fairest buds of fairest tree. 


\section{$D A F F O D I L$. \\ (Unrequited Love.)}

HE name of this flower is only a corruption of Dis's lily, as it is supposed to be the flower that dropped from Pluto's chariot when he was carrying off Proserpine to the infernal regions. Jean Ingelow, in the beautiful poem of "Persephone," thus introduces this flower into a resuscitation of the antique fable:

"She stepped upon Sicilian grass,

Demeter's daughter fresh and fair,

A child of light, a radiant lass,

And gamesome as the morning air.

The daffodils were fair to see,

They nodded lightly on the lea.

"Lo! one she marked of rarer growth

Than orchis or anemone ;

For it the maiden left them both, And parted from her company.

Drawn nigh, she deemed it fairer still,

And stooped to gather by the rill

The daffodil, the daffodil.

"What ailed the meadow that it shook?

What ailed the air of Sicily?

She wondered by the brattling brook,

And trembled with the trembling lea.

' The coal-black horses rise-they rise!

O mother, mother!' low she cries.

" 'O light, O light !' she cries, 'farewell;

The coal-blacli horses wait for me.

O shade of shades, where I must dwell, Demeter, mother, far frnm thee! 
Oh, fated doom that I fulfil !

Oh, fateful flower beside the rill !

The daffodil, the daffodil !"

Chaucer alludes to this story, and Shakspeare intro duces it into his "Winter's Tale :"

"O Proserpina,

For the flowers now that, frighted, thou lett'st fall

From Dis's waggon : daffodils

That come before the swallow dares, and take

The winds of March with beauty."

\section{DAFFODILS.}

HERRICK.

FAIR daffodils, we weep to see

Ye haste away so soon ;

As yet the early-rising sun

Has not attained his noon :

Stay, stay,

Until the hastening day

Has run

But to the even-song,

And, having prayed together, we

Will go with ye along.

We have short time to stay as ye,

We have as fleet a Spring,

As quick a growth to meet decay

As you or anything:

We die

As your hours do, and dry

Away 
Like to the Summer's rain, Or as the pearls of morning's dew, Ne'er to be found again.

\section{A F F O I L S.}

WORDSWORTH.

I WANDERED lonely as a cloud

That floats on high o'er vales and hills,

When all at once I saw a crowd,

A host of golden daffodils,

Beside the lake, beneath the trees,

Fluttering and dancing in the breeze.

Continuous as the stars that shine

And twinkle in the milky-way,

'They stretched in never-ending line

Along the margin of a bay.

Ten thousand saw I at a glance,

Tossing their heads in sprightly dance.

The waves beside them danced; but they

Outdid the sparkling waves in glee:

A poet could not but be gay,

In such a jocund company ;

I gazed-and gazed-but little thought

What wealth the show to me had brought:

For oft when on my couch I lie,

In vacant or in pensive mood,

They flash upon that inward eye

Which is the bliss of solitude;

And then my heart with pleasure fills,

And dances with the daffodils. 


\section{$V I O L E T$.}

(Modesty.)

"The violet is for modesty."-Burns.

IOLETS, considered by some as typical of mociesty, by others are deemed emblematic of faithfulness; and the latter have the support of one of Shakspeare's contemporary poets :

"Violet is for faithfulness, Which in me shall abide;

Hoping likewise that from your heart You will not let it slide."

"The violet was as proud a device of the Innic Athenians," says a well-known author, "as the rose of England and the lily of France. In all seasons it was to be seen exposed for sale in the market-place at Athens, the citizens being successful in rearing it in their gardens even when the ground was covered with snow."

The Greeks called this flower "Ion," and it was said that Jupiter caused the first violet to spring up in the grass, when the unhappy Io, metamorphosed into a heifer, bent her lips to eat.

Perdita, when wishing for flowers to give her guests, in the "Winter's Tale," thus speaks of the beauty and perfume of violets : 

"Violets dim,
But sweeter than the lids of Juno's eyes,
Or Cytherea's breath."

The frequent allusions made to "the nodding violet" by our great dramatist cause it to be regarded as his favourite flower; and in the eyes of many, the fact will not be one of its slightest charms. There is not a more exquisite passage in the whole range of English poetry than that in "Twelfth Night," where the Duke, listening to plaintive music, desires

"That strain again; it had a dying fall :

Oh, it came o'er my ear like the sweet South

That breathes upon a bank of violets,

Stealing and giving odour."

Shakspeare employs his beloved flower as the type of modesty and maidenhood. Indeed, poets are continually using this retiring blossom as an emblem of those qualities

"She steals timidly away,

Shrinking as violets do in Summer's ray."-MOORE.

Barry Cornwall gives it the preference over the rose

"The king told Gyges of the purple flower;

It chanced to be the flower the boy liked most :

It has a scent as though Love, for its dower,

Had on it all his odorous arrows tost ;

For though the rose has more perfuming power,

The violet-haply 'cause 'tis almost lost, And talies us so much trouble to discoverStands first with most, but always with a lover."

"No flowers grew in the vale, Kissed by the dew, wooed by the gale-

None by the dew of the twilight wet,

So sweet as the deep blue violet."-I. E. L.

"When the grave shall open for me-

I care not how soon that time may be- 
Never a rose shall grow on that tomb, It breathes too much of hope and bloom; But there be that flower's meek regret, The bending and deep blue violet." - L. E. L.

Whilst the first Napoleon was in exile, this little blossom was adopted by his followers as an emblem; he was styled Père la Violette, and a small bunch of violets hung up in the house, or worn by a Frenchman, denoted the adherence of the wearer to his fallen chieftain's cause. It is still the emblem of the Bonapartes.

The White Violet, which is not invariably scentless, as is sometimes erroneously presumed, is emblematic of candour, although some authors adopt it as the representative of innocence.

\section{TO A FADING VIOLET.}

SHELLEY.

THE colour from the flower is gone, Which like thy sweet eyes smiled on mc;

The odour from the flower is flown, Which breathed of thee, and only thee!

A withered, lifeless, vacant form, It lies on my abandoned breast, And mocks the heart which yet is warm, With cold and silent rest.

I weep-my tears revive it not; I sigh -it breathes no more on me;

Its mute and uncomplaining lot

Is such as mine should be. 


\section{VIOLETS.}

J. MOULTRIE.

UNDER the green hedges after the snow, There do the dear little violets grow,

Hiding their modest and beautiful heads

Under the hawthorn in soft mossy beds.

Sweet as the roses, and blue as the sky,

Down there do the dear little violets lie,

Hiding their heads where they scarce may be seen;

By the leaves you may know where the violet hath been.

\section{POETRY OF THE VIOLET.}

BARRY CORNWALL.

I LOVE all things the seasons bring,

All buds that open, birds that sing,

All hues from white to jet;

All the sweet words that summer sends

When she recalls her flowery friends,

But chief-the violet.

I love-how much I love! - the rose,

On whose soft lips the south wind blows

In pretty, amorous threat;

The lily paler than the moon,

The odorous, wondrous world of June,

Yet more-the violet!

She comes, the first, the fairest thing

That Heaven upon the earth doth fling,

Ere Winter's star has set; 
She dwells behind her leafy screen, And gives, as angels give, unseen, So, love-the violet.

What modest thoughts the violet teaches, What gracious boons the violet preaches,

Bright maiden, ne'er forget !

But learn, and love, and so depart, And sing thou, with thy wiser heart,

"Long live the violet!"

\section{THE ANGRY VIOLETS.}

DRAYTON.

The pansy and the violet here, As seeming to descend

Both from one root, a very pair,

For sweetness do contend.

And pointing to a pink to tell

Which bears it, it is loth

To judge it; but replies, for smell,

That it excels them both.

Wherewith displeased they hang their heads,

So angry soon they grow,

And from their odoriferous beds

Their sweets at it they throw.

\section{VIOLETS.}

\section{MISS LANDON.}

I Do love violets.

They tell a history of woman's love; 
They open with the earliest breath of spring;

Lead a sweet life of perfume, dew, and light,

And if they perish, perish with a sigh

Delicious as that life. On the hot June

They shed no perfume; the flowers may remain,

But the rich breathing of their leaves is past;

Like woman, they have lost their loveliest gift

When yielding to the fiery hour of passion.

-The violet-breath of love is purity.

\section{I O L E T S.}

BARTON.

BEAUTIFUl are you in your lowliness;

Bright are your hues, delicious in your scent,

Lovely your modest blossoms downward bent,

As shrinking from our gaze, yet prompt to bless

The passers-by with fragrance, and express

How gracefully, though mutely, eloquent

Are unobtrusive worth, and meek content,

Rejoicing in their own obscure recess.

Delightful flowerets! at the voice of Spring

Your buds unfolded to its sunbeams bright,

And though your blossoms soon shall fade from sight,

Above your lonely birthplace birds shall sing,

And from your clustering leaves the glowworm fling

The emerald glory of its earth-born light.

\section{A BOUQUET OF SPRING VIOLETS}

\section{SHELLEY.}

AfTEr the slumber of the year

The woodland violets reappear; 
All things revive in field and grove, And sea and sky; but two, which move And form all others, life and love.

\section{A VIOLET BANK.}

SHAKSPEARE.

I kNOw a bank whereon the wild thyme blows; Where oxlips and the nodding violet grows : Quite over-canopied with lush woodbine, With sweet musk roses and with eglantine.

\section{A BOUQUET OF VIOLETS.}

\section{LEIGH HUNT.}

WE are violets blue,

For our sweetness found

Careless in the mossy shades,

Looking on the ground.

Love's dropped eyelids and a kiss,Such our breath and blueness is.

Io, the mild Shape,

Hidden by love's fears,

Found us first i' the sward, when she

For hunger stooped in tears.

Wheresoe'er her lips she sets, Jove said, "be breaths called violets." 


\section{THE YELLOW VIOLET.}

BRYANT.

When beechen buds begin to swell,

And woods the blue-bird's warble know,

The yellow violet's modest bell

Peeps from the last year's leaves below.

Ere russet fields their green resume,

Sweet flower, I love, in forest bare, To meet thee, when thy faint perfume

Alone is in the virgin air.

Of all her train, the hands of Spring,

First plant thee in the watery mould,

And I have seen thee blossoming

Beside the snow-bank's edges cold.

Thy parent sun, who bade thce view Pale skies, and chilling moisture sip, Has bathed thee in his own bright hue, And streaked with jet thy glowing lip.

Yet slight thy form, and low thy seat, And earthward bent thy gentle eye, Unapt the passing view to meet,

When loftier flowers are flaunting nigh.

Oft, in the sunless April day,

Thy early smile has stayed my walk;

But 'midst the gorgeous blooms of May,

I passed thee on thy humble stalk. 
So they, who climb to wealth, forget

The friends in darker fortunes tried,

I copied them-but I regret

That I should ape the ways of pride.

And when again the genial hour

Awakes the painted tribes of light,

I'll not o'erlook the modest flower

That made the woods of April bright.

\section{SONNET.}

SHAKSPEARE.

THE forward violet thus did I chide :

Sweet thief, whence didst thou steal thy sweet that smells,

If not from my love's breath? The purple pride

Which on thy soft cheek for complexion dwells in my love's veins thou hast too grossly dyed. The lily I condemned for thy hand, And buds of marjoram had stolen thy hair :

The roses fearfully on thorns did stand, One blushing shame, another white despair :

A third, nor red nor white, had stolen of both, And to his robbery had annexed thy breath ;

But, for his theft, in pride of all his growth A vengeful canker eat him up to death : More flowers I noted, yet I none could see, But sweet or colour it had stolen from thee. 


\section{THE ALPINE VIOLET.}

\section{BYRON.}

THE Spring is come, the violet's gone, The first-born child of the early sun; With us she is but a winter flower, The snow on the hills cannot blast her bower; And she lifts up her dewy eye of blue, To the youngest sky of the self-same hue.

But when the Spring comes with her host Of flowers, that flower, beloved the most, Shrinks from the crowd, that may confuse Her heavenly odours and virgin hues.

Pluck the others, but still remember Their herald, out of dire December; The morning star of all the flowers, The pledge of daylight's lengthened hours; And 'mid the roses, ne'er forget The virgin, virgin violet.

\section{'THE VIOLET.}

BARRY CORNWALL.

THE virgin violet, The nun, who, nestling in her cell of leaves, Shrinks from the world in vain. 


\section{NARCISSUS.}

(Self-love.)

洅 HE white or poetical Narcissus is adopted as the emblem of egotism, because, according to the mythologists, it owes its origin to a beautiful youth of Bœotia, of whom it had been foretold that he should live happily until he beheld his own face. One day, when heated by the chase, Narcissus sought to quench his thirst in a stream; in so doing he beheld the reflection of his own features, of which he immediately became enamoured. He was spellbound to the spot where he pined to death, and was metamorphosed by the gods into the flower that now bears his name. When the Naiads had prepared the funeral pile for Narcissus, his body was missing :

"Instead whereof a yellow flower was found, With tufts of white about the button crowned ;"

and ever since is seen

"Narcissus fair,

As o'er the fabled fountain hanging still."

The poetic Narcissus has a snow-white flower, with a yellow cup in the centre, fringed on the border with a brilliant crimson circlet. It is sweet scented, and flowers in May. The cup in the centre is supposed to contain 


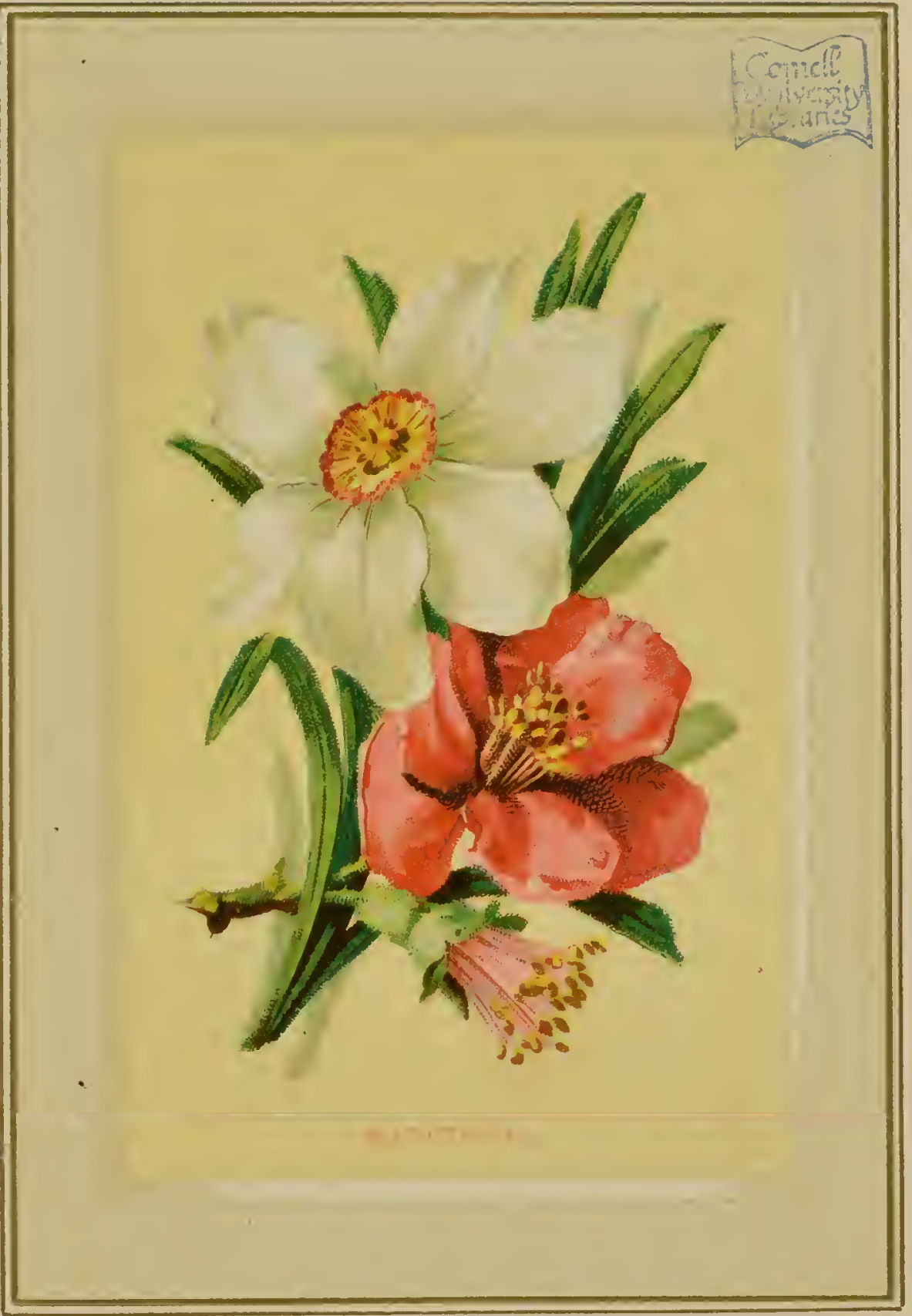


2 
the tears of the ill-fated Narcissus. Keats terms it "a lovely flower :"

"A meek and forlorn flower, with nought of pride."

And Shelley speaks thus of it :

"The pied windflowers and the tulip tall, And Narcissi, the fairest among them all, Who gaze on their eyes in the stream's recess, Till they die at their own dear loveliness."

\section{ECHO AND NARCISSUS.}

\section{MILTON.}

SwEET Echo, sweetest nymph, that liv'st unseen

Within thy aëry shell,

By slow Meander's margent green,

And in the violet-embroidered vale,

Where the love-lorn nightingale

Nightly to thee her sad song mourneth well;

Canst thou not tell me of a gentle pair

That likest thy Narcissus are?

$$
\mathrm{O} \text {, if thou have }
$$

Hid them in some flowery cave,

Tell me but where,

Sweet queen of parley, daughter of the sphere,

So mayst thou be translated to the skies,

And give resounding grace to all heaven's harmonie:

\section{NARCISSUS.}

LET long-lived pansies here their scents bestow, The violet languish, and the roses glow ; 
In yellow glory let the crocus shine, Narcissus here his love-sick head recline ; Here hyacinths in purple sweetness rise, And tulips tinged with beauty's fairest dyes

\section{TO A MIRROR.}

FROM GARCILASO DE LA VEGA.

SINCE still my passion-pleading strains

Have failed her heart to move, Show, mirror, to that lovely maid,

The charms that make me love.

Reflect on her the thrilling beam

Of magic from her eye;

So, like Narcissus, she shall gaze,

And, self-enamoured, die.

\section{DEATH OF NARCISSUS.}

ADDISON.

THEN on th' unwholesome earth he gasping lies Till death shuts up those self-admiring eyes. To the cold shades his flitting ghost retires, And in the Stygian waves itself admires.

For him the Naiads and the Dryads mourn, Whom the sad Echo answers in her turn:

And now the sister nymphs prepare his urn; When, looking for his corpse, they only found A rising stalk, with yellow blossoms crowned. 


\section{NARCISSUS.}

COWPER.

I saw the pride of all the meadows

At morn, a gay Narcissus blow

Upon a river's bank, whose shadow

Bloomed in the silver waves below.

By noontide's heat its youth was wasted,

The waters as they passed complained;

At eve its glories all were blasted,

And not one tormer grace remained.

\section{TO THE NARCISSUS.}

BEN JONSON.

ARISE, and speak thy sorrows, Echo, rise ; Here, by this fountain, where thy love did pine,

Whose memory lives fresh to vulgar fame,

Shrined in this yellow flower, that bears his name.

ECHO.

His name revives, and lifts me up from earth;-

See, see, the mourning fount, whose springs weep yet.

Th' untimely fate of that too beauteous boy,

That trophy of self-love, and spoil of nature,

Who (now transformed into this drooping flower)

Hangs the repentant head back from the stream :

As if it wished,--would I had never looked

In such a flattering mirror! O Narcissus!

Thou that wast once (and yet art) my Narcissus.

Had Echo but been private with thy thoughts,

She would have dropt away herself in tears,

Till she had all turned waste, that in her 
(As in a truer glass) thou mightst have gazed, And seen thy beauties by more kind reflection. But self-love never yet could look on truth, But with bleared beams; slick flattery and she Are twin-born sisters, and do mix their eyes, As if you sever one, the other dies. Why did the gods give thee a heavenly form And earthly thoughts to make thee proud of it? Why do I ask? 'Tis now the known disease That beauty hath, to bear too deep a sense Of her own self-conceived excellence. Oh hadst thou known the worth of Heaven's rich gift. Thou wouldst have turned it to a truer use, And not (with starved and covetous ignorance) Pined in continual eyeing that bright gem The glance whereof to others had been more Than to thy famished mind the wide world's store.

\section{THE NARCISSUS.}

KEATS.

WHAT first inspired a bard of old to sing Narcissus pining o'er the untainted spring? In some delicious ramble he had found A little space, with boughs all woven round; And in the midst of all a clearer pool Than ere reflected in its pleasant cool The blue sky, here and there serenely peeping, Through tendril wreaths fantastically creeping. And on the bank a lonely flower he spied, A meek and forlorn flower, with nought of pride, Drooping its beauty o'er the watery clearness, To woo its own sad image into nearness : 
Deaf to light Zephyrus it would not move, But still would seem to droop, to pine, to love. So while the poet stood in this sweet spot, Some fainter gleamings o'er his fancy shot; Nor was it long ere he had told the tale Of young Narcissus, and sad Echo's wail.

\section{THE NARCISSUS.}

GAY.

HERE young Narcissus o'er the fountain stood, And viewed his image in the crystal flood; The crystal flood reflects his lovely charms, And the pleased image strives to meet his arms. No nymph his inexperienced breast subdued, Echo in vain the flying boy pursued. Himself alone, the foolish youth admires, And with fond look the smiling shade desires; O'er the smooth lake with fruitless tears he grieves. His spreading fingers shoot in verdant leaves; Through his pale veins green sap now gently flows. And in a short-lived flower his beauty blows. Let vain Narcissus warn each female breast, That beauty's but a transient good at best; Like flowers it withers with th' advancing year, And age like winter robs the blooming fair.

\section{THE NARCISSUS.}

MISS LANDON.

The pale and delicate Narcissus' flowers Bending so languidly, as still they found In the pure wave a love and destiny. 


\section{BUTTERCUPS. \\ (Riches-Memories of Childhood.)}

奥 EAUTIFULLY does our great poet, Robert Browning, call these emblems of riches, "the buttercups, the little children's dower."

\section{BUTTERCUPS.}

E. COOK.

"Tis sweet to love in childhood, when the souls that we bequeath

Are beautiful in freshness as the coronals we wreathe:

When we feed the gentle robin, and caress the leaping hound,

And linger latest on the spot where buttercups are found: When we seek the bee and ladybird with laughter, shout, and song,

And think the day for wooing them can never be too long.

Oh! 'tis sweet to love in childhood, and though stirred by meanest things,

The music that the heart yields then will never leave its stings. 
'Tis sweet to love in after years the dear one by our side;

To dote with all the mingled joys of passion, hope, and pride;

To think the chain around our breast will hold still warm, and fast,

And grieve to know that death must come to break the link at last.

But when the rainbow span of bliss is waning, hue by hue; When eyes forget their kindly beams, and lips become less true;

When stricken hearts are pining on through many a lonely hour,

Who would not sigh "'tis safer far to love the bird and flower?'

'Tis sweet to love in ripened age the trumpet blast of Fame,

To pant to live on Glory's scroll, though blood may trace the name;

'Tis sweet to love the heap of gold, and hug it to our breast, -

To trust it as the guiding star and anchor of our rest.

But such devotion will not serve-however strong the zeal-

To overthrow the altar where our childhood loved to kneel. Some bitter moment shall o'ercast the sun of wealth and power,

And then proud man would fain go back to worship bird and flower. 


\section{HAWTHORN.}

(Hope.)

T. $Y$ the Greeks the hawthorn was deemed one of the fortunate trees. The Romans accounted it a symbol of marriage because it was carried at the rape of the Sabines; it was ever after considered propitious. Its flowering branches were borne aloft at their marriages, and the newly-wedded pair were even lighted to the nuptial chamber with torches of its wood.

The Turks regard the presentation of a branch of hawthorn as denoting the donor's desire to receive from the object of his affection that token of love denominated a kiss.

Ronsard-sometimes styled the French Chaucerwrote a beautiful address to the hawthorn, thus faithfully rendered :

"Fair hawthorn flowering,

With green shade bowering

Along this lovely shore;

'To thy foot around

With his long arms wound

A wild vine has mantled thee o'er.

"In armies twain, ked ants have ta'en

Their fortress beneath thy stock;

And in clefts of thy trunk

'Tiny bees have sunk

A cell where honey they lock. 
" In merry Spring-tide,

When to woo his bride

The nightingale comes again,

Thy boughs among

He warbles his song,

That lightens a lover's pain.

"Gentle havthorn, thrive,

And, for ever alive,

May'st thou blossom as now in thy prime;

By the wind unbroke,

And the thunder-stroke,

Unspoiled by the axe of time."

\section{Chaucer thus sings of it:}

"Furth goth all the Courte, both most and lest, To fetche the flouris freshe, and braunche and blome And namely hauthorne brought both page and grome, With freshe garlandis partly blew and white, And than rejoisin in their grete delight.

"Amongst the many buds proclaiming May (Decking the meads in holiday array, Striving who shall surpass in bravery) Mark the fair blooming of the hawthorn tree;

Who, finely clothed in a robe of white, Feeds full the wanton eye with May's delight, Yet for the bravery that she is in Doth neither handle card nor wheel to spin, Nor changeth robes but twice; is never seen In other colours than in white or green.

Learn then, content, young shepherd, from this tree, Whose greatest wealth is Nature's livery."

Spenser tells us in his "Shepherd's Calendar,"

"Youth's folk now flocken everywhere, To gather may-baskets and smelling breere; And home they hasten the posts to dight, And all the kirk-pillars ere daylight, With hawthorn-buds, and sweet eglantine, And garlands of roses, and sops-in-wine."

Herrick, in his "Hesperides," has a beautiful idyi] descriptive of the manner in which maids went a-Maying. 


\section{TO CORINNA, TO GO A-MAYING.}

GET up, get up for shame: the blooming Morn

Upon her wings presents the god unshorn.

See how Aurora throws her fair

Fresh-quilted colours through the air ;

Get up, sweet slug-a-bed, and see

The dew bespangling herb and tree.

Each flower has wept and bowed toward the east

Above an hour since, yet you are not drest,

Nay, not so much as out of bed;

When all the birds have matins said,

And sung their thankful hymns: 'tis sin,

Nay profanation, to keep in,

When as a thousand virgins on this day

Spring sooner than the lark to fetch in May.

Rise and put on your foliage, and be seen

To come forth, like the Spring-time, fresh and green,

And sweet as Flora. Take no care

For jewels for your gown or hair ;

Fear not, the leaves will strew

Gems in abundance upon you;

Besides, the childhood of the day has kept,

Against you come, some orient pearls unwept;

Come, and receive them while the light

Hangs on the dew-locks of the night;

And Titan on the eastern hill

Retires himself, or else stands still

Till you come forth. Wash, dress, be brief in praying;

Few beads are best when once we go a-Maying. 


\section{GOING A-MAYING.}

JOHN INGRAM.

OH, we will go a-Maying, love, A-Maying we will go,

Beneath the branches swaying, love,

With weight of scented snow.

Laburnum's golden tresses, love,

Float in the perfumed air;

Which heedless their caresses, love,

Seeks violets in their lair;

And with their scents a-playing, love,

It gambols to and fro-

Where we will go a-Maying, love,

Where we will Maying go.

The bees are busy humming, love,

Amid the opening blooms,

Foretelling Summer's coming, love-

Farewell to wintry glooms.

The primrose pale, from crinkly sheen,

Up from the ground now speeds;

And cowslips slim, 'mid leafy green,

Rise in the unknown meads.

And buttercups are weighing, love,

The gold they soon must strow-

Where we will go a-Maying, love,

Where we will Maying go.

The hawthorn's bloom is falling, love,

We must no longer wait;

Each bird is blithely calling, love,

Unto his chosen mate; 
Each bud unblown is swelling, love,

Green grow the vernal fields;

Each insect leaves its dwelling, love,

And all to Summer yields :

The mowers are out haying, love,

Woodbine is in full blow-

Where we will go a-Maying, love,

Where we will Maying go.

\section{GOING A-MAYING.}

ELIZA COOK.

My own land! my own land! where freedom finds her throne-land;

Fair thou art, and rare thou art, to every true-born son. Though no gold ore veins thee, though no grape-juice stains thee,

We've harvest fields, and quartered shields, well kept and nobly won.

And we have pleasant tales to tell,

And spot in many a native dell,

Which we may prize and love as well

As Troubadour his story.

The lilting troll and roundelay

Will never, never pass away,

That welcomed in the herald day

Of Summer's rosy glory.

And goodly sight of mirth and might, In blood that gained us Cressy's fight, Was hearts and eyes, all warm and bright 
About the high and gay pole;

When flower bedight, 'mid leaves and light, Shouts echoed - as it reared upright-

Of "Hurrah for merry England, and the raising of the Maypole!"

When the good old times had carol rhymes,

With morris games and village chimes;

When clown and priest shared cup and feast,

And the greatest jostled with the least, At the "raising of the Maypole!"

My brave land! my brave land! oh ! mayest thou be my grave-land;

For firm and fond will be the bond that ties my heart to thee.

When Summer's beams are glowing, when Autumn's gusts are blowing,

When Winter's clouds are snowing, thou art still right dear to me.

But yet, methinks, I love thee best

When bees are nurst on whitethorn breast,

When Spring-tide pours in, sweet and blest,

And joy and hope come dancing!

When music from the feathered throng

Breaks forth in merry marriage song,

And mountain streamlets dash along,

Like molten diamonds glancing!

$\mathrm{Oh} !$ pleasant 'tis to scan the page,

Rich with the theme of bygone age,

When motley fool and learned sage,

Brought garlands for the gay pole;

When laugh and shout came ringing out

From courtly knight and peasant lout, 
In "Hurrah for merry England, and the raising of the Maypole!"

When the good old times had carol rhymes,

With morris games and village chimes;

When clown and priest shared cup and feast,

And the greatest jostled with the least,

At the "raising of the Maypole !"

\section{TO MAY.}

Come, beautiful May!

Like youth and loveliness,

Like her I love; O come in thy full dress;

The drapery of dark winter cast away;

To the bright eye and the glad heart appear,

Queen of the Spring and mistress of the year.

Yet, lovely May!

Teach her whose eyes shall rest upon this rhyme To spurn the gilded mockeries of time,

The heartless pomp that beckons to betray, And keep, as thou wilt find, that heart each year Pure as thy dawn, and as thy sunset clear. 


\section{$P R I M R O S E$}

(Youth.)

"The primrose I will pu', the firstling of the year."-BuRNs.

HE Primrose, emblematical of youth, has received innumerable deservedly warm encomiums from our poets, but none sweeter than those popular lines of Carew :-

"Ask me why I send you here This firstling of the infant year; Ask me why I send to you This primrose all bepearled with dew ; I straight will whisper in your ears The sweets of love are washed with tears.

"Ask me why this flower doth show So yellow, green, and sickly too; Ask me why the stalk is weak And bending, yet it doth not break; I must tell you, these discover What doubts and fears are in a lover."

Shakspeare, whose floral symbolism was perfect, introduces this delicate blossom into his pathetic drama of "Cymbeline," as typical of the youthful dead:

"With fairest flowers,

Whilst Summer lasts, and I live here, Fidele,

I'll sweeten thy sad grave : thou shalt not lack

The flower that's like thy face, pale primrose."

Again, in the "Winter's Tale," the grand dramatist 
still more exquisitely expresses his knowledge of its symbolic character :

"The pale primroses,

That die unmarried ere they can behold

Bright Phœbus in his strength."

Milton also styles this vernal bloom "the pale primrose." It was described by Carew as "the firstling of spring;" thus Burns also terms it in "The Posie," and Linnæus appropriately named it in his botanical system; whilst in his native Swedish it is known as Maj-nycklar, or the "key of May." Its English appellation is derived from primus - "the first"-and happily expresses one of its charms, and shows why it is such a meet emblem of youth.

This fragile flower is known classically as Paralisos, and was thus styled in commemoration of a youth so named, who pined away with grief for the loss of his betrothed, Melicerta, and was metamorphosed into

"The rathe primrose that, forsaken, dies."

It has been observed of poor Clare that his poems are as thickly strewn with primroses as the woodlands themselves. In his "Village Minstrel" he sings :

"Oh, who can speak his joys when Spring's young morn From wood and pasture opened on his view, When tender green buds blush upon the thorn, And the first primrose dips his leaves in dew?

"And while he plucked the primrose in its pride, He pondered o'er its bloom 'tween joy and pride And a rude sonnet in its praise he tried, Where nature's simple way the aid of art supplied."

In another place he tells how, as a child, he rambled o'er the fields for flowers, and 
" Robbed every primrose-root I net, And ofttimes got the root to set; And joyful home each nosegay bore; And felt-as I shall feel no more."

In the following lines the old poet, Browne, associates this flower with a scene of rustic idle thoughtlessness :

"As some wayfaring man, passing a wood, Goes jogging onl, and in his mind nought hath, But how the primrose finely strews the path."

And the sketch is suggestive of Wordsworth's oftquoted idea, in "Peter Bell :"

"A primrose by a river's brim A yellow primrose was to him,
And it was nothing more."

\section{THE PRIMROSE.}

MRS. HEMANS.

I SAw it in my evening walk,

A little lonely flower;

Under a hollow bank it grew,

Deep in a mossy bower.

An oak's gnarled root to roof the cave

With gothic fretwork sprung,

Whence jewelled fern, and arum-leaves,

And ivy garlands hung.

And close beneath came sparkling out

From an old tree's fallen shell

A little rill that clipt about

The lady in her cell. 
And then, methought, with bashful pride She seemed to sit and look On her own maiden loveliness, Pale imaged in the brook.

No other flower, no rival grew

Beside my pensive maid; She dwelt alone, a cloistered nun, In solitude and shade.

No ruffling wind could reach her there; No eye, methought, but mine, Or the young lambs that came to drink, Had spied her secret shrine.

And there was pleasantness to me In such belief-cold eyes That slight dear Nature's loveliness, Profane her mysteries.

\section{THE EARLY PRIMROSE.}

HENRY KIRKE WHITE.

MiLD offspring of a dark and sullen sire! Whose modest form, so delicately fine,

Was nursed in whirling storms,

And cradled in the winds.

Thee, when young Spring first questioned Winter's sway;

And dared the sturdy blusterer to the fight,

Thee on this bank he threw,

To mark his victory. 
In this low vale, the promise of the year, Serene, thou openest to the nipping gale,

Unnoticed and alone,

Thy tender elegance.

So virtue blooms, brought forth amid the storms Of chill adversity; in some lone walk

Of life she rears her head, Obscure and unobserved;-

While every bleaching breeze that on her blows.

Chastens her spotless purity of breast,

And hardens her to bear

Serene, the ills of life.

\section{PRIMROSES.}

KEATS.

A TUFT of evening primroses,

O'er which the mind may hover till it dozes ;

O'er which it well might take a pleasant sleep,

But that 'tis ever startled by the leap

Of buds into ripe flowers.

\section{SAD PRIMROSES.}

PROFESSOR WILSON.

Bur we have daisies, which, like love

Or hope, spring everywhere ; And primroses, which droop above Some self-consuming care. 
So sad, so spiritual, so pale,

Born all too near the snow,

They pine for that sweet southern gale, Which they will never know.

\section{TO A PRIMROSE}

PRESENTED TO A FRIEND IN JANUARY.

CARRINGTON.

SweEt herald of the ever gentle spring, How gently waved o'er thee the winter's wing: Around thee blew the warm Favonian gale, Devonia nursed thee in her loveliest vale; Beneath she rolled the Plym's pellucid stream, tnd heaven diffused around its quickening beam. But, ah! the sun, the shower, the zephyr bland, Made thee but fair to tempt the spoiler's hand. I cannot bear thee to thy bank again, And bathe thy breast in soft refreshing rain, Nor bid the gentle zephyr round thee piay, Nor 'raptured eye thee basking in the ray; But snapped untimely from thy velvet stem, Be thou my daily care, my "bonnie gem," And when thus severed from thy native glade, The radiance of thy cinque-rayed star shall fade, And pale decay come creeping o'er thy bloom, A sigh, dear flower, shall mourn thy early doom. 


\section{THE PRIMROSE.}

MRS. HUNTER.

THE sun declines, his parting ray,

Shall bear the cheerful light away,

And on the landscape close :

Then will I seek the lonely vale,

Where sober evening's primrose pale

To greet the night star blows.

Soft melancholy bloom, to thee

I turn, with conscious sympathy,

Like thee my hour is come;

When length'ning shadows slowly fade,

Till lost in universal shade,

They sink beneath the tomb.

By thee I'll sit, and inly muse,

What are the charms in life we lose

When time demands our breath.

Alas! the load of lengthened age

Has little can our wish engage,

Or point the shaft of death.

No, 'tis alone the pang to part

With those we love, that rends the heart:

That agony to save,

Some nameless cause in nature strives;

Like thee in shades, our hope revives,

And blossoms in the grave. 


\section{THE PRIMROSE OF THE ROCK.}

WORDSWORTH.

A ROCK there is whose lonely front

The passing traveller slights;

Yet there the glowworms hang their lamps,

Like stars, at various heights;

And one coy primrose to that rock

The vernal breeze invites.

What hideous warfare hath been waged,

What kingdoms overthrown,

Since first I spied that primrose tuft,

And marked it for my own!

A lasting link in nature's chain

From highest heaven let down.

The flowers, still faithful to the stems,

Their fellowship renew;

The stems are faithful to the root,

That worketh out of view ;

And to the rock the root adheres,

In every fibre true.

Close clings to earth the living rock,

Though threatening still to fall;

The earth is constant to her sphere,

And God upholds them all :

So blooms this lonely plant, nor dreads,

Her annual funeral.

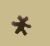


Here closed the meditative strain;

But air breathed soft that day,

The hoary mountain-heights were cheered,

The sunny vale looked gay;

And to the primrose of the rock

I gave this after lay.

I sang-Let myriads of bright flowers,

Like thee, in field and grove,

Revive unenvied ; -mightier far,

Than tremblings that reprove

Our vernal tendencies to hope,

Is God's redeeming love ;

That love which changed-for wan disease,

For sorrow that had bent,

O'er hopeless dust, for withered age-

Their moral element,

And turned the thistles of a curse

To types beneficent.

Sin-blighted though we are, we too,

The reasoning sons of men,

From our oblivious winter called,

Shall rise and breathe again ;

And in eternal summer lose

Our threescore years and ten.

To humbleness of heart descends

This prescience from on high, The faith that elevates the just,

Before and when they die;

And makes each soul a separate heaven,

A court for Deity. 


\section{TO PRIMROSES.}

ROBERT HERRICK.

WHy do ye weep, sweet babes? can tears

Speak grief in you,

Who were but born

Just as the modest morn

Teemed her refreshing dew?

Alas! you have not known that shower

That mars a flower;

Nor felt the unkind

Breath of a blasting wind;

Nor are ye worn with years;

Or warped as we

Who think it strange to see

Such pretty flowers, like to orphans young, Speaking by tears before ye have a tongue.

Speak, whimpering younglings, and make known

'The reason why

Ye droop and weep;

Is it for want of sleep,

Or childish lullaby?

Or that ye have not seen as yet

\section{The violet?}

Or brought a kiss

From that sweetheart to this?

No, no; this sorrow, shown

By your tears shed,

Would have this lecture read :

That things of greatest, so of meanest worth, Conceived with grief are, and with tears brought forth. 


\section{A BOUQUET.}

M. E. LEE.

Primroses,

Which when the shadows fall

Like soft dreams o'er the earth, And all around a Sabbath reigns

As at Creation's birth, Burst the magic bonds of clay,

And greet with smiles the sun's last ray.

\section{CROLX.}

THE flowers are Nature's jewels, with whose wealth She decks her summer beauty; Primrose sweet, With blossoms of pure gold; enchanting Rose, That like a virgin queen salutes the sun, Dew-diademed.

\section{ANON.}

OF maiden modesty and tender truth The Primrose is the type; as 'tis of youth. 


\section{HYACINTH. \\ PURPLE HYACIN TH.}

\section{(Sorrow-Play.)}

9. CCORDING to the mythologists, this fairy-like fragile flower had its origin in the death of Hyacinthus, a Spartan youth, greatly favoured by Apollo. He fell a victim to the jealous rage of Zephyrus, who, in revenge for the preference manifested for him by the Sun-god, had determined to effect his destruction. Accordingly, one day when Hyacinthus was playing at quoits with his divine friend, Zephyrus blew so powerfully upon the quoit flung by Apollo that it struck the unfortunate prince on the temple and killed him, to the intense grief of his innocent slayer. To com memorate the grace and beauty of the dead youth, Apollo, unable to restore him to life, caused the flower which now bears his name to spring from his blood.

An annual solemnity, called Hyacinthia, was established in Laconia in honour of Hyacinthus. It lasted three days, during which the people, to show their grief for the loss of their darling prince, ate no bread, but fed upon sweetmeats, and abstained from adorning their hair with garlands as on ordinary occasions. 
The following day was spent in feasting. Hence, perhaps, one of the floral meanings- "Play." The purple hyacinth signifies sorrow, as it is said to bear on its petals Apollo's lament for his friend-Ai, $\mathrm{Ai}$-but we fail to trace the letters now.

An allusion to Hyacinthus will also be recognised in Milton's "Lycidas :"

"Like to that sanguine flower inscribed with woe."*

\section{THE HYACINTH.}

CASIMIR.

CHILD of the Spring, thou charming flower,

No longer in confinement lie,

Arise to light, thy form discover,

Rival the azure of the sky.

The rains are gone, the storms are o'er,

Winter retires to make thee way;

Come, then, thou sweetly blooming flower,

Come lovely stranger, come away.

The sun is dressed in beaming smiles,

To give thy beauties to the day:

Young zephyrs wait with gentlest gales,

To fan thy bosom as they play.

* Apollo wrote on its leaves his lament, $A i, A i$. 


\section{HYACINTHUS.}

KEATS.

Or they might watch the quoit-pitchers, intent On either side, pitying the sad death Of Hyacinthus, when the cruel breath Of Zephyr slew him ; Zephyr penitent, Who now, ere Phœbus mounts the firmament,

Fondles the flower amid the sobbing rain.

\section{HYACINTH.}

\section{EBENEZER ELLIOTT.}

ShADE-LOving Hyacinth! thou comest again, And thy rich odours seem to swell the flow

Of the lark's song, the redbreast's lonely strain, And the stream's tune-best sung where wildflowers blow-

And ever sweetest where the sweetest grow.

\section{HAREBELL (oR Hyacinth).}

BROWNE.

THE Harebell for her stainless azure hue, Claims to be worn of none but those are true. 


\section{$R O S E M A R Y$.}

(Remembrance.)

"There's roscmary for you: that's for remembrance."

Shakspeare.

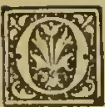

UR forefathers invariably adopted Rosemary as the symbol of remembrance; it was believed to possess the power of improving the memory, and was frequently employed as a means of invigorating the mental faculties. Perdita, in the "Winter's Tale," says :

"For you there's rosemary and rue; these keep Seeming and savour all the winter long:

Grace and remembrance be with you both!"

And in "Hamlet," Ophelia says :

"There's rosemary for you: that's for remembrance.

Pray you, love, remember."

Michael Drayton, in his "Pastorals," also alludes to this emblem in similar terms :

"He from his lass him lavender hath sent, Showing her love, and doth requital crave; Him rosemary his sweetheart, whose intent Is that he her should in remembrance have."

Respecting its employment at funerals, Mr. Martyn observes that in some parts of England, in his time, it was still customary to distribute it among the company, 
who frequently threw sprigs of it into the grave. Slips of it were also sumetimes placed within the coffin; and in some secluded villages these innocent customs are still practised.

\section{TO THE HERB ROSEMARY.}

HENRY KIRKE WHITE.

SweET scented flower! who art wont to bloom

On January's front severe,

And o'er the wintry desert drear,

To waft thy waste perfume!

Come, thou shalt form my nosegay now,

And I will bind thee round my brow,

And as I twine the mournful wreath,

I'll weave a melancholy song,

And sweet the strain shall be and long,-

The melody of death.

Come, funeral flower! who lovest to dwell

With the pale corse in lonely tomb,

And throw across the deepest gloom

A sweet decaying smell.

Come, press my lips, and lie with me,

Beneath the lowly alder tree;

And we will sleep a pleasant sleep,

And not a care shall dare intrude

To break the marble solitude,

So peaceful and so deep.

And hark! the wind god as he flies,

Moans hollow in the forest trees,

And sailing on the gusty breeze,

Mysterious music dies. 
Sweet flower! that requiem wild is mine,

It warns me to the lowly shrine,

The cold turf altar of the dead;

My grave shall be in yon lone spot,

Where, as I lie, by all forgot,

A dying fragrance thou wilt o'er my ashes shed.

\section{DIE HERZ BLUME.}

TOM HOOD.

There grew a little flower once,

That blossomed in a day,

And some said it would ever bloom,

And some 'twould fade away;

And some said it was Happiness,

And some said it was Spring,

And some said it was Grief and Tears,

And many such a thing;

But still the little flower bloomed,

And still it lived and throve,

And men do it call "Summer Growth,"

But angels call it "Love!"

\section{ROSEMARY.}

Honey sweet from thee is won,

Floweret, bending in the sun!

Sweet remembrances beside

In thy silvery leaf, abide,

Thoughts of love and thoughts of death,

Linger in thy fragrant breath 


\section{THE LILY OF THE VALLEY. \\ (Return of Happiness.)}

"Be thy advent the emblem of all I would crave."

BERNARD BARTON.

Gंत्: HE Lily of the Valley, sometimes called the May Lily, and in some country villages Ladder to Heaven, in the floral languages of Europe is emblematic of the return of happiness, doubtless in allision to the season of the year when it puts forth its blossoms.

Keats was very fond of it, and says :

"No flower amid the garden fairer grows

Than the sweet lily of the lowly vale,

The queen of flowers."

And further on

$$
\begin{aligned}
& \text { "Vralley-lilies, whiter still } \\
& \text { Than Leda's love." }
\end{aligned}
$$

In that enchanted garden where the sensitive plant grew, Shelley lovingly placed

"The naiad-like lily of the vale,

Whom youth makes so fair, and passion so pale, That the light of its tremulous bells is seen

Through their pavilions of tender green." 


\section{THE CHILD AND LILY.}

BRYANT.

INNOCENT child and snow-white flower!

Well are ye paired in your opening hour,

Thus should the pure and the lovely meet,

Stainless with stainless, and sweet with swect.

White, as those leaves just blown apart,

Are the folds of thy own young heart;

Guilty passion and cankering care

Never have left their traces there.

Artless one! though thou gazest now

O'er the white blossoms with earnest brow,

Soon will it tire thy childish eye,

Fair as it is, thou wilt throw it by.

Throw it aside in thy weary hour,

Throw to the ground the fair white flower,

Yet, as thy tender years depart,

Keep that white and innocent heart.

\section{THE LILY OF THE VALLEY.}

CROLY.

WhiTe bud ! that in meek beauty so dost lean,

The cloistered cheek as pale as moonlight snow

Thou seem'st beneath thy huge high leaf of green,

An Eremite beneath his mountain's brow.

White bud! thou'rt emblem of a lovelier thing,-

The broken spirit that its anguish bears

To silent shades, and there sits offering

To Heaven, the holy fragrance of its tears. 


\section{THE I I L Y.}

PERCIVAL.

I HAD found out a sweet green spot Where a lily was blooming fair;

The din of the city disturbed it not;

But the spirit that shades the quiet cot With its wings of love was there.

I found that lily's bloom When the day was dark and chill:

It smiled like a star in a misty gloom, And it sent abroad a sweet perfume, Which is floating around me still.

I sat by the lily's bell, And watched it many a day:-

The leaves, that rose in a flowing swell,

Grew faint and dim, then drooped and fell, And the flower had flown away.

I looked where the leaves were laid, In withering paleness, by;

And as gloomy thoughts stole on me, said, There's many a sweet and blooming maid Who will soon as dimly die.

\section{THE LILY.}

COLERIDGE.

THE stream with languid murmur creeps

In Lumin's flowery vale :

Beneath the dew the lily weeps,

Slow waving to the gale. 
"Cease, restless gale !" it seems to say,

"Nor wake me with thy sighing!

The hours of my vernal day

On rapid wings are flying.

"To-morrow shall the traveller come

Who late beheld me blooming;

His searching eye shall vainly roam

The dreary vale of Lumin."

\section{LILY OF THE VALLEY.}

There is a pale and modest flower, In garb of green arrayed,

'That decks the rustic maiden's bower,

And blossoms in the glade.

Though other flowers around me bloom,

In gaudy splendour drest,

Filling the air with rich perfume,

I love the lily best.

I see the tulip's gorgeous hue,

And sunflower's crown of gold;

I see the rose and woodbine, too,

Their scented leaves unfold:

Though they adorn the gay parterrc,

I love them not as well

As the drooping lily, frail and fair,

That grows in shady deli. 


\section{PIMPERNEL.}

(Change.)

"More bitter far than all

It was to know that love could change and die."

A. A. Proctek.

闰 $\mathrm{HE}$ Pimpernel does not unfold its brilliant petals until eight o'clock in the morning, and refolds them towards noon : this habit has obtained for it the cognomen of "the poor man's weather-glass;" whilst for its usefulness in foretelling the approach of rain, it is frequently known as "the shepherd's warning." Few who have passed a portion of their life in the country but are acquainted with this property of the pretty little pinpernel. Whenever its tiny scarlet blossoms are seen fold. ing up their delicate petals, it may be deemed a certain indication of approaching rain; and as such a sign Darwin notices it :

"Closed is the pink-eyed pimpernel;

In fiery red the sun doth rise, Then wades through clouds to mount the skies;

"Twill surely rain, we see 't with sorrow, -

No working in the fields to-morrow."

"All earthly things must change and die,"

This is the lesson of the flower

That closes when a storm is nigh

And will not face a dreary hour. 


\section{PIMPERNEL. \\ O. W. HOLMES.}

Some years ago, a dark-eyed maid

Was sitting in the shade-

There's something brings her to my mind

In that young dreaming maid-

And in her hand she held a flower,

A flower whose speaking hue

Said, in the language of the heart,

"Believe the giver true."

And as she looked upon its leaves,

The maiden made a vow

To wear it when the bridal wreath

Was woven for her brow.

She watched the flower, as, day by day,

The leaflets curled and died;

But he who gave it never came

To claim her for his bride.

Oh, many a Summer's morning glow

Has lent the rose its ray,

And many a Winter's drifting snow

Has swept its bloom away;

But she has kept that faithless pledge

To this her Winter hour,

And keeps it still, herself alone,

And wasted like the flower. 


\section{$H E A R T^{\prime} S-E A S E$; \\ OR, \\ P A NSY. \\ (Think of me-Thoughts.)}

"There are pansies : that's for thoughts."-SHAKsPEARE.

HE Heart's-ease, as its French name of pansy or pensée intimates: is in the language of flowers symbolical of remembrance. It is a beautiful variety of the violet, far surpassing that flower in diversity and brilliancy of colour, but possessing little, if any, of the exquisite fragrance for which that is so renowned.

The name given to it by the Italians is fammola, the "little flame," at least, this is an appellation with which I have met, and it is quite in the taste of that poetical people. The French call it pensée, "a thought." "There are pansies," says poor Ophelia: "that's for thoughts." Drayton, in the "Muses' Elysium," makes his nymph say-

"Amongst these roses in a row,

Next place I pinks in plenty, These double daisies then for show, And will not this be dainty? The pretty pansy then I'll tye, Like stones some chain enchasing; The next to them, their near ally, The purple violet placing. 


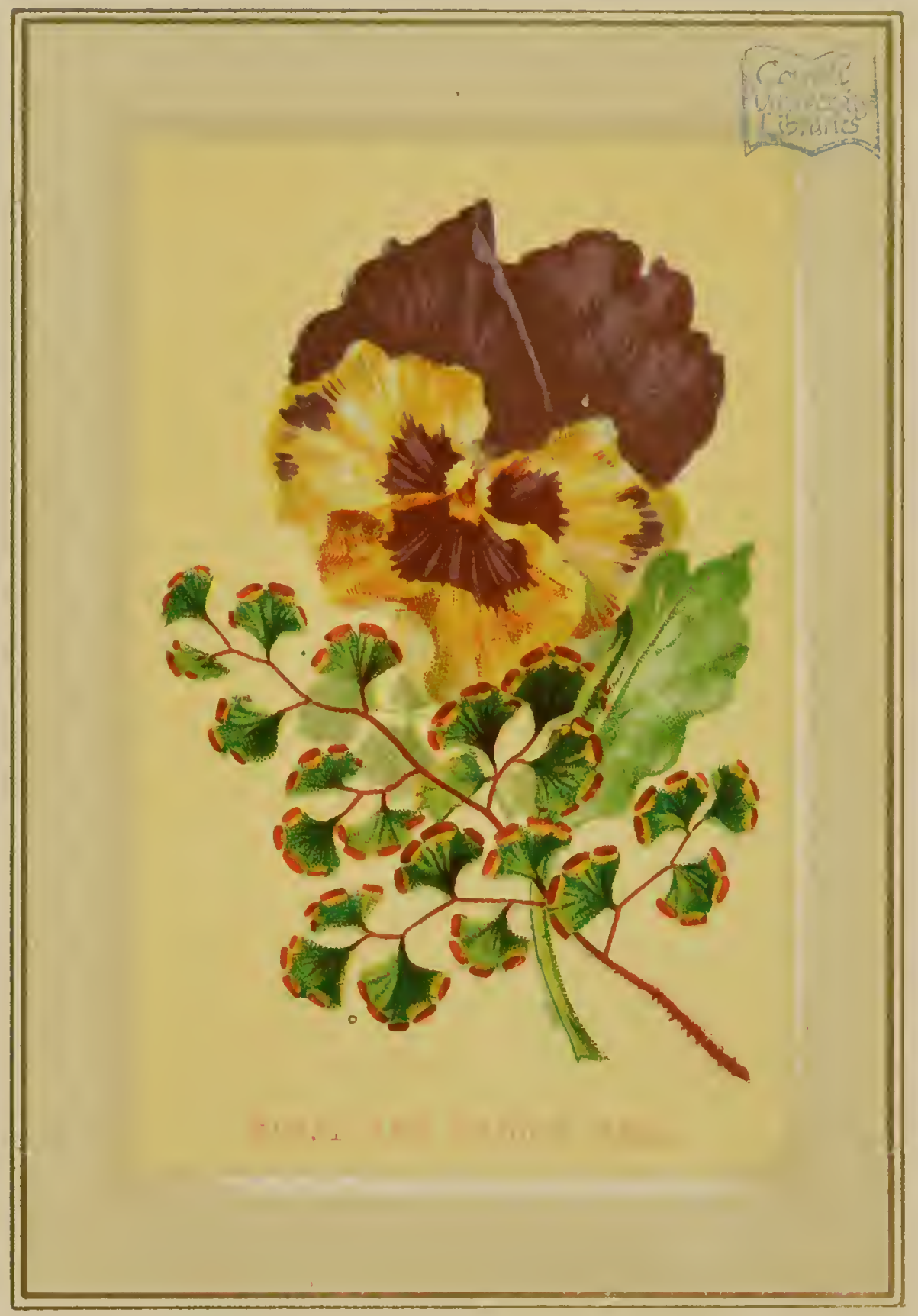



Another of its names is "love-in-idleness," under which it has been again celebrated by Shakspeare.

Besides these names, this tricoloured violet is also called, in various country places, "jump-up-and-kiss-mequick ;" "the herb Trinity ;" "three-faces-under-a-nood ;" "kiss-me-behind-the-garden-gate;" and "cuddle-me-toyou," which seems to have been altered by time into the less vivacious request of "call-me-to-you."

\section{HEART'S EASE。}

MARY HOWITT.

HEART'S-EASE! one could look for half a day

Upon this flower, and shape in fancy out

Full twenty different tales of love and sorrow,

That gave this gentle name.

\section{ORIGIN OF THE PANSY'S NAME.}

\section{("Love in Idleness.")}

Told by Oberon, King of the Fairies, to Puck.-Shakspeare.

Oberon. My gentle Puck, come hither; thou re. member'st

Since once I sat upon a promontory, And heard a mermaid, on a dolphin's back, Uttering such dulcet and harmonious breath, That the rude sea grew civil at her song, And certain stars shot madly from their spheres To hear the sea-maid's music.

Puck. I remember. 
Oberon. That very tume I saw (but thou couldst not) Flying between the cold moon and the earth, Cupid all armed : a certain aim he took At a fair vestal throned by the west; And loosed his love-shaft smartly from his bow, As it should pierce a hundred thousand hearts. But I might see young Cupid's fiery shaft Quenched in the chaste beams of the wat'ry moon, And the imperial votress passed on, In maiden meditation, fancy free. Yet marked I where the bolt of Cupid fell. It fell upon a little western flower Before, milk-white; now purple with love's wound,And maidens call it "Love-in-Idleness."

\section{PANSIES.}

ROBERT BUCHANAN.

"The lily minds me of a maiden brow," Hugh Sutherland would say ; " the marigold Is full and sunny like her yellow hair, The full-blown rose her lips with sweetness tipt, But if you seek a likeness to her eye,Go to the pansy, friend, and find it there." "Ay, leeze me on the pansies!" Hugh would say, Hugh Sutherland, the weaver,-he who dwelt Here in the whitewashed cot you fancy so,Who knew the learnèl names of all the flowers, And recognised a lily, though its head Rose in a ditch of dull Latinity!

Pansies? You praise the ones that grow to-day Here in the garden: liad you seen the place 
When Sutherland was living! Here they grew

From blue to deeper blue, in midst of each

A golden dazzle like a glimmering star,

Each broader, bigger than a silver crown ;

While here the weaver sat, his labour done,

Watching his azure pets and rearing them

Until they seemed to know his step and touch,

And stir beneath his smile like living things!

The very sunshine loved them, and would lie

Here happy, coming early, lingering late,

Because they were so fairs

\section{HEART'S EASE.}

MRS. SHERIDAN.

In gardens oft a beauteous flower there grows,

By vulgar eyes unnoticed and unseen;

In sweet security it humbly blows,

And rears its purple head to deck the green.

This flower, as Nature's poet sweetly sings,

Was once milk-white, and Heart's-ease was its name,

Till wanton Cupid poised his roseate wings,

A vestail's sacred bosom to inflame.

With treacherous aim the god his arrow drew,

Which she with icy coldness did repel;

Rebounding thence with feathery speed it flew,

Till on this lonely flower at last it fell.

Heart's-ease no more the wandering shepherd found;

No more the nymphs its snowy form possess ;

Its white now changed to purple by Love's wound,

Heart's-ease no more,-'tis Love-in-idleness. 


\section{HEART'S EASE.}

ANON.

I USED to love thee, simple flower, To love thee dearly when a boy ; For thou didst seem in childhood's hour, The smiling type of childhood's joy.

But now thou only work'st my grief, By waking thoughts of pleasures fled. Give me, give me the withered leaf, That falls or Autumn's bosom dead.

For that ne'er tells of what has been, But warns me what I soon shall be;

It looks not back on pleasure's scene, But points unto futurity.

I love thee not, thou simple flower, For thou art gay, and I am lone; Thy beauty died with childhood's hourThe heart's-ease from my path is gone. 


\section{WALLFLOWER. \\ (Fidelity in Misfortune.)}

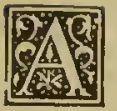

COMMON garden blossom, that seldom receives all the attention it is worthy of, is the Wallfower, symbolical of fidelity in misfortune. It was a great favourite in the Middle Ages, when troubadours and minstrels wore it as an emblem of the unchangeableness of their affection. Wallflowers belong to the Stock family; and by far the finest is the common one, which Thomson, in his "Seasons," describes as-

"The yellow wallflower, stained with iron brown."

Bernard Barton says of the wallflower :

"An cmblem true thou art, Of love's enduring lustre, given To cheer a lonely heart."

And elsewhere :

"To me it speaks of loveliness, That passes not with youth, Of beauty which decay can bless, Of constancy and truth.

"Ijut in adversity's dark hour, When glory is gone by, It then exerts its gentle power, Tha scene to beautify." 


\section{THE WALLFLOWER.}

MOIR.

THE wallflower-the wallflower,

How beautiful it blooms!

It gleams above the ruined tower,

Like sunlight over tombs!

It sheds a halo of repose

Around the wrecks of time;-

To beauty give the flaunting rose,

The wallflower is sublime.

Flower of the solitary place!

Grey ruin's golden crown!

Thou lendest melancholy grace

To haunts of old renown;

Thou mantlest o'er the battlement,

By strife or storm decayed;

And fillest up each envious rent

Time's canker-tooth hath made.

Whither hath fled the choral band

That filled the abbey's nave?

Yon dark sepulchral yew-trees stand

O'er many a level grave;

In the belfry's crevices the dove

Her young brood nurseth well,

Whilst thou, lone flower ! dost shed above

A sweet decaying smell.

In the season of the tulip cup,

When blossoms clothe the trees,

How sweet to throw the lattice up,

And scent thee on the breeze! 
The butterfly is then abroad,

The bee is on the wing,

And on the hawthorn by the road

The linnets sit and sing.

Sweet wallflower-sweet wallflower!

Thou conjurest up to me,

Full many a soft and sunny hour

Of boyhood's thoughtless glee;

When joy from out the daisies grew

In woodland pastures green,

And summer skies were far more blue

Than since they e'er have been.

Now autumn's pensive voice is heard Amid the yellow bowers,

The robin is the regal bird, And thou the queen of flowers!

He sings on the laburnum trees,

Amid the twilight dim,

And Araby ne'er gave the breeze

Such scents as thou to him.

Rich is the pink, the lily gay,

The rose is summer's guest ;

Bland are thy charms when these decay-

Of flowers, first, last, and best !

There may be gaudier on the bower,

And statelier on the tree;

But wallflower, loved wallflower,

Thou art the flower for nse! 


\section{THE WALIFLOWER.}

\section{LANGHORNE.}

"Why loves my flower, the sweetest flower,

'That swells the golden breast of May.

'Thrown rudely o'er yon ruined tower, To waste her solitary day.

"Why, when the mead, the spicy vale, The grove and genial garden call, Will she her fragrant soul exhale, Unheeded on the lonely wall?

"For never sure was beauty born To live in death's deserted shade! Come, lovely flower, my banks adorn; My banks, for life and beauty made."

Thus pity waked the tender thoughtAnd, by her sweet persuasion led, To seize the hermit flower I sought And bear her from her stony bed:

I sought-but sudden on my ear A voice in hollow murmurs broke, And smote my heart with holy fear, The Genius of the ruin spoke:

«From thee be far th' ungentle deed, The honours of the dead to spoil, Or take the sole remaining meed, 'i'he flower that crowns their former toil. 
"Nor deem that flower the garden's foe,

Or fond to grace this barren shade;

'Tis nature tells her to bestow

Her honours on the lonely dead.

"For this, obedient zephyrs bear

Her light seeds round yon turret's mould, And, undispersed by tempests there,

They rise in vegetable gold.

"Nor shall tiny wonder wake to see Such desert scenes distinction crave;

Oft have they been, and oft shall be

Truth's, honour's, valour's, beauty's grave.

"Where longs to fall that rifted spire,

As weary of the insulting air,

'The poet's thought, the warrior's fire,

The lover's sighs are sleeping there.

"When that, too, shakes the trembling ground, Borne down by some tempestuous sky, And many a slumbering cottage round Startles-how still their hearts will lie!

"Of them who, wrapt in earth so cold, No more the smiling day shall view, Should many a tender tale be told, For many a tender thought is due.

" Hast thou not seen some lover pale, When evening brought the pensive hour, Step slowly o'er the shadowy vale, And stop to pluck the frequent fiower : 
"Those flowers he surely meant to strew On lost affection's lowly cell,

Though there, as fond remembrance grew, Forgotten from his hand they fell.

"Has not for thee the fragrant thorn Been taught her first rose to resign, With vain but pious fondness borne To deck thy Nancy's honoured shrine!

" 'Tis Nature pleading in the breast, Fair memory of her works to find; And when to fate she yields the rest, She claims the monumental mind.

"Why, else, the o'ergrown paths of time Would thus the lettered sage explore; With pain these crumbling ruins climb And on the doubtful sculpture pore?

"Why seeks he with unwearied toil, Through death's dim walk to urge his way; Reclaim his long-asserted spoil, And lead oblivion into day?

"Tis Nature prompts, by toil or fear

Unmoved, to range through death's domain; The tender parent loves to hear.

Her children's story told again.

"Treat not with scorn his thoughtful hours, If haply near these haunts he stray; Nor take the fair enlivening flowers That bloom to cheer his lonely way." 


\section{THE WALLFLOWER.}

H. F. LYTE.

WHY loves my flower, so high reclined

Upon these walls of barren gloom, To waste her sweetness on the wind, And far from every eye to bloom? Why joy to twine with golden braid This ruined rampart's aged head, Proud to expose her gentle form, And swing her bright locks in the storm?

That lonely spot is bleak and hoar,

Where prints my flower her fragrant kiss;

Yet sorrow hangs not fonder o'er

The ruins of her faded bliss.

And wherefore will she thus inweave The owl's lone couch, and feel at eve The wild bat o'er her blossoms fling, And strike them down with heedless wing?

Thus gazing on the loftiest tower Of ruined Fore at eventide, The Muse addressed a lonely flower That bloomed above in summer pride, The Muse's eye, the Muse's ear, Can more than others see and hear: The breeze of evening murnured by, And gave, she deemed, this faint reply :- 
"On this lone tower, so wild and drear, 'Mid clouds and storms I love to lie, Because I find a freedom here

Which prouder haunts could ne'er supply.

Safe on these walls I sit, and stem

The elements that conquered them; And high o'er reach of plundering foe, Smile on an anxious world below.

"Though envied place I may not claim,

On warrior's crest, or lady's hair ;

Though tongue may never speak my name,

Nor eye behold and own me fair; To Him who tends me from the sky,

I spread my beauties here on high, And bid the winds to waft above, My incense to His throne of love.

"And though in hermit solitude, Aloft and wild, my home I choose, On the rock's bosom pillowed rude, And nurtured by the falling dews; Yet duly with the opening year I hang my golden mantle here. A child of God's I am, and $\mathrm{He}$ Sustains, and clothes, and shelters me.

"Nor deem my state without its bliss:

Mine is the first young smile of day;

Mine the light zephyr's earliest kiss;

And mine the skylark's matin lay.

These are my joys : with these on high In peace I hope to live and die, 
And drink the dew, and scent the breeze, As blithe a flower as Flora sees."

Bloom on, sweet moralist! Be thine

The softest shower, the brightest sun!

Long o'er a world of error shine,

And teach them what to seek and shun.

Bloom on, and show the simple glee

That dwells with those who dwell like thee;

From noise, and glare, and folly driven,

To thought, retirement, peace, and Heaven.

Show them, in thine, the Christian's lot, So dark and drear in worldly eyes;

And yet he would exchange it not

For all they most pursue and prize.

From meaner cares and trammels free,

He soars above the world, like thee;

And fed and nurtured from above,

Returns the debt in grateful love.

Frail, like thyself, frail flower, is he,

And beat by every storm and shower;

Yet on a Rock he stands, like thee,

And braves the tempest's wildest power.

And there he blooms and gathers still

A good from every seeming ill;

And pleased with what his lot has given,

He lives to God, and looks to Heaven. 


\section{THE WALLFLOWER.}

ANON.

Cheerful 'midst desolation's sadness-thou-

Fair flower, art wont to grace the mouldering pile And brightly bloom o'er ruin, like a smile

Reposing calm on age's furrowed brow-

Sweet monitor! an emblem sure I see Of virtue, and of virtue's power, in thee. For though thou cheerest the dull ruin's gloom, Still when thou'rt found upon the gay parterre, There thou art sweetest-fairest of the fair ;So virtue, while it robs of dread the tomb, Shines in the crown that youth and beauty wear, Being best of all the gems that glitter there.

\section{THE NAMING OF THE WALLFLOWER.} HERRICK.

WHy this flower is now called so, List, sweet maids, and you shall know. Understand this firstling was

Once a brisk and bonny lass, Kept as close as Danaë was, Who a sprightly springald loved; And to have it fully proved, Up she got upon a wall, 'Tempting down to slide withal; But the silken twist untied, So she fell, and, bruised, she died. 
Jove, in pity of the deed, And her loving, luckless speed, Turned her to this plant we call Now "the flower of the wall."

\section{THE WALLFLOWER.}

THy banner waves abrove the tower Which Time and Ruin make their own, Most faithful in the dreariest hour; Such is thy praise-and thine alone!

Meet emblem art thou of the heart Which in misfortune fastest clings; And when our friends and wealth depart,

Love's mantle o'er us fondly flings.

\section{FIDELITY}

Faithful in the time of ruin;

To the lonely clinging still, Friendship's truest tender'st duty Gentle flower! thou dost fulfil.

May we find a friend as faithful

When misfortune's clouds may low'r,

Clinging like this little flow'ret

Closer in our dreariest hour. 


\section{FORGET-ME-NOT.}

.

HIS iovely little flower has a charming legend attached to it. We give it in its best poetic form at once.

\section{THE BRIDE OF THE DANUBF. \\ MISS PICKERSGILL.}

"SEE how yon glittering wave in sportive play, Washes the bank, and steals the flowers away. And must they thus in bloom and beauty die, Without the passing tribute of a sigh?"

"No, Bertha, those young flowerets there Shall form a braid for thy sunny hair;

I yet will save them, if but one Soft smile reward me when 'tis done." He said, and plunged into the streamHis only light was the moon's pale beam. "Stay! stay!" she cried—but he had caught The drooping flowers, and breathless sought To place the treasures at the feet Of her from whom e'en death were sweet. 
With outstretched arms upon the shore she stood,

With tearful eye she gazed upon the flood,

Whose swelling tide now seemed as if 'twould sever

Her faithful lover from her arms for ever.

Still through the surge he panting strove to gain

The welcome strand-but, ah! he strove in vain!

Yet once the false stream bore him to the spot Where stood his bride in muteness of despair: And scarcely had he said, "Forget me not!" And flung the dearly ransomed flowerets there, When the dark wave closed o'er him, and no more, Was seen young Rodolph on the Danube's shore.

Aghast she stood; she saw the tranquil stream Pass o'er him-could it be a fleeting dream? Ah, no! the last fond words, "Forget me not!" Told it was all a sad reality.

With frantic grasp the dripping flowers she prest, Too dearly purchased, to her aching breast.

Alas! her tears, her sorrows now were vain, For him she loved she ne'er shall see again! Is this then a bridal, where, sad in her bower, The maid weeps alone at the nuptial hour; Where hushed is the harp, and silent the luteAh! why should their thrilling strains be mute? And where is young Rodolph? where stays the bridegroom?

Go, ask the dark waters, for there is his tormh.

Often at eve when maidens rove Beside the Danube's wave, 
They tell the tale of hapless love, And show young Rodolph's grave; And cull the flowers from that sweet spot, Still calling them "Forget-me-Not."

\section{THE LEGEND OF THE FORGET-ME-NOT.} ANONYMOUS.

FAREWELL! my true and loyal knight! on yonder battle field

Many a pearl and gem of price will gleam on helm and shield:

But bear thou on thy silver crest this pure and simple wreath,

A token of thy ladye's love-unchanging to the death.

They seem, I know, these fragrant flowers, those fairy stars of blue,

As maidens' eyes had smiled on them, and given them that bright hue;

As only fitting but to bind a lady's hair or lute, And not with war or warrior's crest in armed field to suit.

But there's a charm in every leaf, a deep and mystic spell; Then take the wreath, my loyal knight, our Lady shield thee well;

And though still prouder favours deck the gallant knights of France,

Oh, be the first in every field, La Fleur de Souvenance!

How bland, how still this summer eve, sure never gentler hour,

For lay of love, or sigh of lute, to breathe in lady's bower; 
Then listen with a lover's faith, as spell-bound to the spot, To the legend of my token flower, the charmed Forgetme-Not.

Young Albert led his Ida forth, when the departing sun Still lingered in the golden west, and shone like treasures won

From some far land of old romance; some genie's diamond throne,

A wreck of bright enchanted gems, in triumph overthrown.

Love, look towards those radiant clouds, so like to fairy bowers :

How proudly o'er a sea of gold are raised their ruby towers ;

And now, as if by magic spell, a bright pavilion seems,

With its folds of sapphire light, where the panting sunray gleams.

To that bright heaven with sniles she looked; one gleam of her blue eyes,

And Albert's heart forgot the clouds, and all their radiant dyes,

All, all, but that young smiling one, whose beauty well might seem

A fairy form of loveliness imagined in a dream.

She took a chaplet from her brow, which, gleaming soft and tair,

Like orient veil of amber light streamed down her silken hair,

Shedding fragrance, emitting brightness from its glitt'ring rings,

As if hallowed by Love's breath, and the glancing of his wings. 
"These maiden roses, love, appear Inke pearls kissed by the sun

With last rich gleam of crimson ere his western throne be won ;

But should there not be some bright flower to deck our bridal wreath,

Whose hue might speak of constancy, unchanging to the death?"

"My Ida! from a thousand wreaths, thy own sweet fallcy chose,

For pure unfading loveliness, this garland of the Rose : And what can speak of truer faith, my own beloved one, 'Than the flower whose fragrance lasts even when its life is gone?"

"Look to yon lone enchanted isle, which 'mid the silvery foam

Of the blue water seems to float, the wild swan's elfin home ;

A very cloud of azure flowers in rich profusion bloom;

Winds of the lake ! your passing sighs breathe of their rich perfume.

"In nameless beauty all unmarked, in solitude they smile, As if they bloomed but for the stars, or birds of that lone isle:

For never yet hath mortal foot touched that enchanter? shore,

Long hallowed by the wildly imagined tales of yore.

"Full well I love those distant flowers, whose pure and tender blue

Seems fitting emblem of a faith, unchanging as their hue; 
And wouldst thou venture for my love as thou wouldst for renown,

To win for me those azure flowers, to deck my bridal crown?"

One parting kiss of his fair bride, and swiftly far away, Like the wild swan whose home he sought, young Albert met the spray

Of rising waves, which foamed in wrath, as if some spirit's hand

Awoke the genii of the lake to guard their mystic land.

The flowers were won, but devious his course lay back again ;

To stem the waters in their tow'ring rage he strove in vain :

Fondly he glanced to the yet distant shore, where in despair

His Ida stood with outstretched arms, 'mid shrieks and tears and prayer.

Darker and fiercer gathered on the tempest in his wrath, The eddying waves with vengeful ire beset the fatal path; With the wild energy of death he well-nigh reached the spot,

The azure flowers fell at her feet- "Ida, Forget me not!"

The words yet borne upon his lips, the prize seemed almost won,

When 'mid the rush of angry waves he sank-for ever gone!

Within a proud cathedral aisle was raised a costly tomb, Whose pure white marble like ethereal light amid the gloom 
Shone-and no other trace it bore of lineage or of lot But Ida's name, with star-like flowers ensculped Forget me not!

There Ida slept, the desolate, the last of all her name, Parted from him who perished for her love 'mid dawn of * fame;

But when shall their fond legend die! or when shall be forgot

The flower that won its name in death, Iove's themeForget-me-not!

\section{FORGET ME NOT.}

W. H. HARRISON.

The star that shines so pure and bright, Like a far-off place of bliss, And tells the broken-hearted

There are brighter worlds than this; The moon that courses through the sky, Like man's uncertain doom, Now shining bright with borrowed light, Now wrapt in deepest gloom,-

Or when eclipsed, a dreary blank, A fearful emblem given

Of a heart shut out by a sinful world From the blessed light of heaven;The flower that freely casts it wealth Of perfume on the gale;

The breeze that mourns the summer's close, With melancholy wail; 
The stream that cleaves the mountain's side,

Or gurgles from the grot,-

All speak in their Creator's name,

And say "Forget me not!"

When man's vain heart is swollen with pride,

And his haughty lip is curled,

And from the scorner's seat he smiles

Contempt upon the world;

Where glitter crowns and coronets,

Like stars that gem the skies,

And Flattery's incense rises thick

To blind a monarch's eyes ;

Where the courtier's tongue with facile lie

A royal ear beguiles;

Where suitors live on promises,

And sycophants on smiles;

Where each as in a theatre

Is made to play his part,

Where the diadem hides a troubled brow,

And the star an aching heart;

There, even 'mid pomp and power,

Is oft a voice that calls

"Forget me not," in thunder,

Throughout the palace walls.

Or in the house of banqueting,

Where the maddening bowl is flush, And the shameless ribald boast of deeds

For which the cheek should blush;

Where from the oft-drained goblet's brim

The eye of mirth is lit;

Where the cold conceits of a trifler's brain

Pass for the coin of wit ; 
Where Flattery sues to woman's ear, And tells his tale again,

And beauty smiles upon things so mean, We blush to call them men;

Where 'tis sad to hear the flippant tongue Apply its hackneyed arts;-

Oh! their heads would be the hollowest things

But for their hollower hearts!

But, hist ! the reveller's shout is stilled,

The song, the jest forgot;

The hair is snapped, the sword descends,

With a dread "Forget me not!"

Go ! hie thee to the rank churchyard

Where flits the shadowy ghost, And see how little pride has left

Whereon to raise a boast.

See Beauty claiming sisterhood

With the noisome reptile worm-

Oh, where are all the graces fled

That once arrayed her form!

Fond hope no more on her smile will feed.

Nor wither at her frown:

Her head will rest more quiet now

Than when it slept on down.

With cloven crest and bloody shroud

The once proud warrior lies;

And the patriot's heart hath not a throb

To give to a nation's cries.

A solemn voice will greet thine ear As thou lingerest round the spot, And cry from out the sepulchre, "Frail man, forget me not!" 
"Forget me not !" the thunder roars,

As it bursts its sulphury cloud;

'Tis murmured by the distant hills

In echoes long and loud;

'Tis written by the Almighty's hand

In characters of flame,

When the lightnings gleam with vivid flash,

And His wrath and power proclaim.

'Tis murmured when the white wave falls

Upon the wreck-strewn shore,

As a hoary warrior bows his crest

When his day of work is o'er.

Go! speed thee forth when the beamy sun

O'erthrows the reign of night,

And strips the scene of its misty robe,

And arrays it in diamonds bright.

Oln! as thou drinkest health and joy

In the fresh and balmy air,

"Forget me not," in a still small voice

Will surely greet thee there.

Oh! who that sees the vermeil cheek

Grow day by day more paile,

And Beauty's form to shrink before

The summer's gentlest gale,

But thinks of Him, the mighty One,

By whom the blow is given,

As if the fairest flowers of earth

Were early plucked for heaven.

Oh! yes, on every side we see

The impress of $\mathrm{His}$ hand ;

The air we breathe is full of Him,

And the earth on which we stand. 
Yet heedless man regards it not,

But life's uncertain day

In idle hopes and vain regrets

Thus madly wastes away.

But in his own appointed time

He will not be forgot:

$\mathrm{Oh}$ ! in that hour of fearful strife,

Great God, forget me not!

\section{FORGET-ME-NOT.}

THERE is a little modest flower,

To friendship ever dear,

'Tis nourished in her humble bower,

And watered by her tear.

If hearts by fond affection tried,

Should chance to slip away,

This little flower will gently chide

The heart that thus would stray.

All other flowers when once they fade

Are left alone to die,

But this e'en when it is decayed,

Will live in memory's sigh.

\section{FORGET ME NOT.}

\section{M. MOIR.}

Summer was on the hills when last we parted.

Now the bright moon is shining O'er the gay mountain and the stilly sea, As, by the streanlet's willowy bend reclining

I pause, remembering thee. 
Yes! as we roamed, the sylvan earth seemed glowing

With many a beauty, unremarked before;

The soul was like a deep urn overflowing

With thoughts, a treasured store;

The very flowers seemed born but to exhale,

As breathed the west, their fragrance to the gale.

Methinks, even yet I feel thy timid fingers

With their bland pressure thrilling bliss to mine;

Methinks, yet on my cheek thy breathing lingers

As-fondly leant to thine,

I told, how life all pleasureless would be,

Green palm-tree of life's desert! wanting thee.

Not yet, not yet had disappointment shrouded

Youth's summer calm with storms of wintry strife;

The star of hope shone o'er our path unclouded,

And fancy coloured life

With those elysian rainbow hues, which Truth

Melts with his rod, when disenchanting youth.

Yet should it cheer me, that nor woe hath shattered

The ties that link our hearts, nor hate nor wrath; And soon the day may dawn, when shall be scattered

All shadows from our path,

For ah! with others wealth and mirth would be

Less sweet, by far, than sorrow shared with thee!

Yes! vainly, foolishly the vulgar reckon,

That happiness resides in outward shows:

Contentment from the lowliest cot may beckon

True love to sweet repose :

For genuine bliss can ne'er be far apart,

When soul meets soul, and heart responds to heart. 


\section{SONG OF THE FORGET-ME-NOT.}

How many bright flowers now around me are glancing, Each seeking its praise, or its beauty enhancing! The rose-buds are hanging like gems in the air, And the lily-bell waves in her fragrance there. Alas! I can claim neither fortune nor power, Neither beauty nor fragrance are cast in my lot; But contented I cling to my lowly bower, And smile while I whisper-Forget-me-not'

\section{FORGET-ME-NOT.}

NEW MONTHLY MAGAZINE.

I CULLED each flow'ret for my fair, The wild thyme and the heather bell ; And round them twined a tendril rare-

She said the posy pleased her well. But of the flowers that deck the field,

Or grace the garden of the cot, Though others richer perfumes yield, The sweetest is forget-me-not.

We roamed the mead, we climbed the hill,

We rambled o'er the breckan brae;

The trees that crowned the mossy rill, They screened us from the glare of day. She said she loved the sylvan bower,

Was charmed with ev'ry rural spot; And when arrived the parting hour, Her last words were "forget-me-not !" 


\title{
CAN YOU FORGET ME?
}

\author{
L. E. L.
}

Autums, while into languid Winter drooping,

Gave its last blossoms, opening but to fall.

Can you forget them:

Can you forget me? I an not relying

On plighted vows-alas! I know their worth

Man's faith to woman is a trifle, dying

Upon the very breath that gave it birth.

\section{FORGET-ME-NOT.}

WITII SOME FORGET-ME-NOTS.

JOHN INGRAM.

DEAR girl, I send this spray of flowers-

All withered now, once brightest blue-

To call to mind those happy hours,

Those happy hours I passed with you.

Forget me not! though others win

The glorious right to call thee "theirs ;"

Forget me not! that might have been

The answer to my fervid prayers.

For I have had thy hand in mine,

And once our ways in life seemed blended;

And once I thought our loves might twine,

But now, alas! that dream is ended.

Forget me not! for I am lonely,

And stranded on Life's desert shore;

Forget me not! - I ask that only-

For now our paths may meet no more. 
Could I but think you don't forget,

Though all my hopes of life should perish.

I'd pass then by without regret,

So that that thought I still might cherish.

Forget me not!' tis all I ask,

And though thy hand may be another's,

I'll wear upon my face a mask

Of smiles to hide the grief it covers.

Let, then, these withered flowers recall

Each broken link of Memory's chain;

And from the Past's dim haunted hall

Those happy hours bring back again.

Forget me not! mine only love-

Ah! would indeed that you were mine !

Forget me not! my long-lost dove,

In dreams my heart will beat next thine!

\section{FORGET ME NOT.}

W. M. PRAED.

When thy sad Master's far away,

Go, happier far than he,

Go, little flower, with her to stay,

With whom he may not be :

There bid her mourn his wayward lot, And whisper still, Forget me not. 


\section{HOLLYHOCK. (Ambition.)}

"The fallen hollyhock."-EBEnEzer ELLIOT.

蒚 $\mathrm{HE}$ emblem of that crime by which Wolsey tells us the angels fell is the tall and stately Hollyhock.

A few years ago it was often designated the "garden mallow," and, indeed, belongs to the mallow family. From the fact that it is known in France as Rose d'outre Mer, or "rose from beyond the sea," it has been surmised that it was first introduced into Europe frcra Syria by the Crusaders.

"Queen Hollyhock, with butterflies for crowns."

The blossom of the Hollyhock is said to furnish a great quantity of bee honey. Considerable benefit would be received by bee-keepers if they planted plenty of Holly. hocks near their hives, for as Horace Smith says,

"From the nectaries of hollyhocks

The liumble bee, e'en till he faints, will sip."

It is a meet emblem of a soaring ambition rising in its stately height above the faded blossoms of summer, glorious in its bunches of many-coloured flowers. The hollyhock forms a good border of colours for lawns and borders of gardens. 


\section{THE ROSE. \\ (Love-Foy-Prosperity.)}

圈輙

E Rose has been acknowledged by all antiquity to be the queen of flowers, though her reign is somewhat disputed by the Queen Lily. One is tempted to look on them both as sister sovereigns of the florai world. The Rose, the emblem of a material dominion "of the earth earthy ;" the Lily, of a spiritual empire of purity and lofty aspiration. But with all peoples the Rose has ever been the emblem of love, joy, and prosperity.

It is mentioned by the earliest writers of antiquity. Herodotus speaks of the double rose; in the Song of Solomon the rose of Sharon is mentioned, and allusion is also made to the plantation of roses at Jericho. Isaiah uses the blossoming of the rose as a perfect emblem of joy and felicity.

The ancients regarded the Rose as the emblem of silence, as well as of love and joy, and frequently represented Cupid offering one to Harpocrates, the God of Silence. As a further illustration of this symbolism, they suspended a rose over the table at feasts, intimating to the assembled guests that the conversation was to be held sacred, and was not to be repeated elsewhere. This latter account is renerally given as the correct derivation of the saying, "sub rosa," applied to communications not to be repeated; 


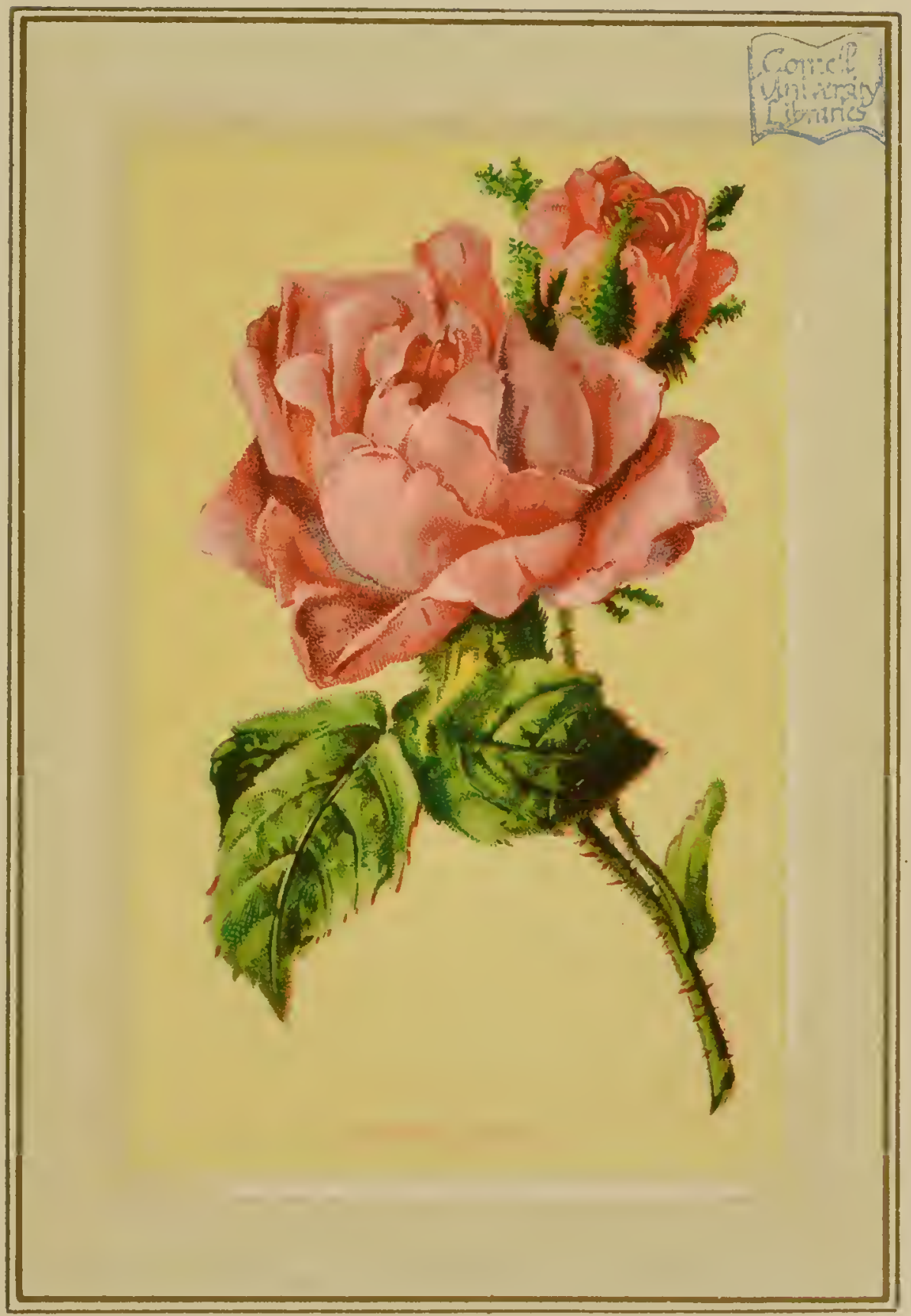



but some writers say that the Rose was once dedicated to Harpocrates, and thus became the emblem of taciturnity, for which reason, it is averred, it is frequently placed over the confessionals in Roman Catholic churches, indicating the secrecy which should attend whatever may be there disclosed to the ears of the priest.

Roses were more highly prized by the Romans than any other flower; they considered them emblematic of joy, and, in conformity with that idea, represented Comus, the God of Pleasure, as a handsome young man, crowned with a garland of roses, the leaves of which glistened with dewdrops.

The Rose was, above all, the emblem of Love :

" Most glorious rose,

You are the queenly belle. On you all eyes

Admiring turn. Doubtless you might indite

Romances from your own sweet history-

They're quite the fashion now, and crowd the pare

Of every periodical. Wilt tell

None of your heart adventures? Never mind :

We plainly read the Zephyr's stolen kiss

In your deep blush ; so where's the use to seal

Your lips so cunningly, when all the voorld

Calls you the flozver of love?"-MRS. SIGOURNEY.

inacreon thus writes of it :

"The rose, the flowver of love, Mingle with our quaffing;

The rose, the lovely leaved,

Round our brows be weaved,

Genially laughing.

"Oh, the rose, the first of flowers,

Darling of the early bowers,

E'en the gods for thee have places;

Thee, too, Cytherea's boy

Weaves about his locks for joy,

Dancing with the Graces.

The short life of this queenly flower causes it, when 
fading, to be deemed a suitable representative of fleeting beauty, and many are the "morals" that the poets have deduced from its brief existence; but there is another record to be made, and that is of its fragrance after death : the flush of beauty may be gone from its withered petals, but the scent of the Rose will cling to it still; and so, even when life is over, we yet place, as Barry Cornwall says:

"First of all the rose, because its breath

Is rich beyond the rest; and when it dies, It doth bequeath a charm to sweeten death."

"The heart doth recognise thee,

Alone, alone! the heart doth smell thee sweet, Doth view thee fair, doth judge thee most complete,

Perceiving all those changes that disguise thee.

Yes, and the heart doth owe thee,

More love, dead rose, than to any roses bold,

Which Julia wears at dances, smiling cold !

Lie still upon this heart, which breaks below thee!"

MrS. Browning.

"Love is like a rose,

And a month it may not see

Ere it withers where it grows."-BAILEy.

Spenser has bequeathed us a very felicitous stanza about the Rose as an emblem of modesty and fragility:

"Ah! see the virgin rose, how sweetly she

Doth first peep forth with bashful modesty,

That fairer seems the less ye see her may!

Lo! see soon after how, more bold and free,

Her bared bosom she doth broad display!

Lo! see soon after how she fades and falls away!"

Sir Walter Scott tells us :

"The rose is fairest when 'tis budding new, And hope is brightest when it dawns from fears;

The rose is sweetest washed with morning dew,

And love is loveliest when embalmed with tears." 


\section{THE DYING ROSEBUD}

MRS. OSGOOD.

Af me! ah, woe is me!

That I should perish now,

With the dear sunlight just let in

Upon my balmy brow.

My leaves, instinct with glowing life,

Were quivering to unclose;

Mv happy heart with love was rife-

I was almost a rose.

Nerved by a hope, rich, warm, intense,

Already I had risen

Above my cage's curving fence,

My green and graceful prison.

My pouting lips, by Zephyr pressed,

Were just prepared to part,

And whisper to the wooing wind

The rapture of my heart.

In new-born fancies revelling,

My mossy cell half-riven,

Each thrilling leaflet seemed a wing

To bear me into heaven.

How oft, while yet an infant flower,

My crimson cheek I've laid

Against the green bars of my bower,

Impatient of the shade; 
And pressing up and peeping through

Its small but precious vistas, Sighed for the lovely light and dew That blessed my elder sisters.

I saw the sweet breeze rippling o'er 'Their leaves that loved the play, Though the light thief stole all the store Of dewdrop gems away.

I thought how happy I should be Such diamond wreaths to wear, And frolic with a rose's glee

With sunbeam, bird, and air.

\author{
Ah me! ah, woe is me! that I, \\ Ere yet my leaves unclose, \\ With all my wealth of sweets, must clie \\ Before I am a rose!
}

\title{
THE LESSON OF A ROSE.
}

SPENSER.

Ан! see whoso fayre thing doest faine to see, In springing flowre the image of thy day! Ah! see the virgin rose, how sweetly shee Doth first peepe foorth with bashfull modestee, That fairer seems the lesse ye see her may! Lo! see soone after how, more bold and free, Her barèd bosome she doth broad display; I o! see soone after how she fades and falls away! 
So passeth, in the passing of a day

Of mortal life, the leafe, the bud, the flowre,

$\mathrm{Ne}$ more doth florish after first decay,

That earst was sought to deck both bed and bowre

Of many a lady, and many a paramowre!

Gather therefore the rose whilest yet is prime;

For soon comes age that will her pride defloure;

Gather the rose of love whilest yet is time,

Whilest loving thou mayst loved be with equal crime.

\section{ZULEIKA'S ROSE.}

BYRON.

A single rose is shedding there

Its lonely lustre, meek and pale:

It looks as planted by despair-

So white, so faint - the slightest gale

Might whirl the leaves on high;

And yet, though storms and blight assail,

And hands more rude than wintry sky

May wring it from its stem; in vain--

To-morrow sees it bloom again!

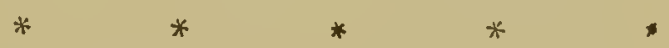

To it the livelong night there sings

A bird unseen, but not remote:

Invisible his airy wings,

But soft as harp that Houri strings

His long entrancing note. 


\section{THE ROSE.}

The rose, o'er crag or vale, Sultana of the nightingale,

The maid for whom his melody,

His thousand songs are heard on high,

Blooms blushing to her lover's tale :

His queen, the garden queen, his rose,

Unbent by winds, unchilled by snows,

Far from the winters of the west,

By every breezc and season blest,

Returns the sweets by nature given

In softest incense back to heaven.

\section{A SONG OF THE ROSE.}

HEMANS.

ROSE ! what dost thou here,

$$
\text { Bridal, royal rose? }
$$

How, 'midst grief and fear,

\section{Canst thou thus disclose}

That fervid hue of love, which to thy heart-leaf glows?

Rose! here too much arrayed

For triumphal hours,

Look'st thou through the shade

Of these mortal bowers,

Not to disturb my soul, thou crowned one of all flowers?

As an eagle soaring

Through a sunny sky,

As a clarion pouring

Notes of victory,

So dost thou kindle thoughts, for earthly life too high- 
Thoughts of rapture, flushing

Youthful poet's cheek,

Thoughts of glory rushing

Forth in song to break,

But finding the spring-tide of rapid song too weak.

Yet, oh! festal rose,

I have seen thee lying

In thy bright repose

Pillowed with the dying,

'Thy crimson by the life's quick blood was flying.

Summer, hope, and love,

O'er that bed of pain,

Met in thee, yet wove

Too, too frail a chain

In its embracing links the lovely to detain.

Smil'st thou, gorgeous flower?-

Oh! within the spells

Of thy beauty's power

Something dimly dwells,

At variance with a world of sorrows and farewells.

All the soul forth flowing

In that rich perfume,

All the proud life glowing

In that radiant bloom,

Have they no place but here, beneath th' o'ershadowing tomb? 
Crown'st thou but the daughters

Of our tearful race?-

Heaven's own purest waters

Well might bear the trace

Of thy consummate form, melting to softer grace.

Will that clime enfold thee

With immortal air?

Shall we not behold thee

Bright and deathless there?

In spirit-lustre clothed, transcendently more fair?

Yes! my fancy sees thee

In that light disclose,

And its dream thus frees thee

From the mist of woes,

Darkening thine earthly bowers, O bridal, royal rose!

\section{THE ROSE.}

\section{ELTON'S SPECIMENS.}

Din Jove a queen of flowers decree,

The rose the queen of flowers should be.

Of flowers the eye; of plants the gem;

The meadow's blush; earth's diadem;

Glory of colours, on the gaze

Lightening in its beauty's blaze;

It breathes of love; it blooms the guest

Of Venus' ever-fragrant breast;

In gaudy pomp its petals spread;

Light foliage trembles round its head;

With vermeil blossoms fresh and fair

It laughs to the voluptuous air. 


\section{GATHER YOUR ROSES.}

ANTHOLOGIA OXONIENSIS.

Live while you live, my boys!

Yet while the lamp doth shine;

Gather your roses

Ere they decline.

Man makes himself both cares and pains; He secks for thorns, and thorns he gains;

But lets, alas! unheeded pass

The violet in his way.

Live while you live, my boys!

Yet while the lamp doth shine;

Gather your roses

Ere they decline.

\section{ODE.}

ANACREON (TRANSLATED BY MOORE).

Buds of roses, virgin flowers

Culled from Cupid's balmy bowers,

In the bowl of Bacchus steep,

Till with crimson drops they weep !

Twine the rose, the garland twine,

Every leaf distilling wine ;

Drink and smile, and learn to think

That we were born to smile and drink 
Rose! thou art the sweetest flower That ever drank the amber shower; Rose! thou art the fondest child Of dimpled spring, the wood-nymph wild!

Even the gods who walk the sky Are amorous of thy scented sigh. Cupid too, in Paphian shades, His hair with rosy fillet braids. Then bring me showers of roses, bring, And shed them round me while I sing.

\section{THE MOSS ROSE.}

FROM THE GERMAN OF KRUMMACHER. THE Angel of the flowers one day, Beneath a rose-tree sleeping lay; That spirit to whose charge 'tis given To bathe young buds in dews of heaven ;Awaking from his light repose, The Ange! whispered to the Rose :" $\mathrm{O}$ fondest object of my care, Still fairest found, where all are fair ; For the sweet shade thou giv'st to me, Ask what thou wilt, 'tis granted thee!" Then said the Rose, with deepened glow, "On me another grace bestow ;" The spirit paused in silent thought,What grace was there that flower had not? 'Twas but a moment-o'er the Rose A veil of moss the Angel throws, And, robed in nature's simplest weed, Could there a flower that Rose exceed? 


\section{THE I.EGACY OF THE ROSES.}

\section{MISS L. E. LANDON.}

$\mathrm{OH}$ ! plant them above me, the soft and bright. The touched with the sunset's crimson light, The warm with the earliest breath of Spring, The sweet with the sweep of the west wind's wing; Let the green bough and the red leaf wave,Plant the glad rose-tree upon my grave.

Why should the mournful willow weep, O'er the quiet rest of the dreamless sleep? Weep for life with its toil and care, Its crime to shun, and its sorrows to bear; Let tears, and the signs of tears be shed Over the living, not over the dead.

Plant not the cypress, nor yet the yew, Too heavy their shadow, too gloomy their hue, For one who is sleeping in faith and love, With a lope that is treasured in heaven above; In a holy trust are my ashes laid,

Cast ye no darkness, throw ye no shade.

Plant the green sod with the crimson rose, Let my friends rejoice o'er my calm repose; Let my memory be like the odours shed, My liope like the promise of early red; Let strangers share in their breath and bloom, Plant ye the bright roses over my tomb. 


\section{THE ROSE.}

WALLER.

Go, lovely rose,

Tell her that wastes her time and me,

That now she knows

When I resemble her to thee,

How sweet and fair she seems to be

Tell her that's young,

And shuns to have her graces spied,

That hadst thou sprung

In deserts where no men abide,

Thou must have uncommended died.

Small is the worth

Of beauty from the light retired;

Bid her come forth,

Suffer herself to be desired,

And not blush so to be admired.

Then die, that she

The common fate of all things rare

May read in thee,

How small a part of time they share,

That are so wondrous sweet and fair.

VERSE ADDED BY KIRKE WHITE.

Yet though thou fade,

From thy dead leaves let fragrance rise,

And teach the maid,

That Goodness Time's rude hand defics;

That Virtue lives when Beauty dies. 


\section{GATHER YE ROSE-BUDS.}

HERRICK.

Gather ye rose-buds while ye may,

Old time is still a-flying;

And this same flower that smiles to-day,

To-morrow will be dying.

The glorious lamp of heaven, the sun,

The higher he's a-getting;

The sooner will his race be run,

The nearer he's a-setting.

That age is best, that is the first,

When youth and blood are warmer;

But being spent, the worse, and worst

Times still succeed the former.

Then be not coy, but use your time;

And while ye may, go marry;

For having lost but once your prime,

You may for ever tarry.

\section{ROSES.}

\section{LEIGH HUNT.}

WE are blushing roses,

Bending with our fulness,

'Midst our close-capped sister buds,

Warming the green coolness. 
Whatsoe'er of beauty,

Yearns and yet reposes,

Blush, and bosom, and sweet breath,

Took a shape in roses.

Hold one of us lightly-

See from what a slender

Stalk we bow in heavy blooms,

And roundness, rich and tender.

Know you not our only

Rival flower-the human?

Loveliest weight on lightest foot,

Joy abundant woman.

\section{ROSES.}

ANACREON.

WHILE we invoke the wreathèd Spring,

Resplendent Rose, to thee we'll sing;

Resplendent Rose! the flower of flowers,

Whose breath perfumes Olympus' bowers;

Whose virgin blush, of chastened dye,

Enchants so much our mortal eye.

Oft has the poet's magic tongue

The Rose's fair luxuriance sung;

And long the Muses, heavenly maids,

Have reared it in their tuneful shades.

When, at the early glance of morn,

It sleeps upon the glittering thorn, 'Tis sweet to dare the tangled fence, 
To cull the timid floweret thence, And wipe, with tender hand, away, The tear that on its blushes lay!

'Tis sweet to hold the infant stems, Yet drooping with Aurora's gems, And fresh inhale the spicy sighs That from the weeping buds arise. When revel reigns, when mirth is high, And Bacchus beams in every eye, Our rosy fillets scent exhale, And fill with balm the fainting gale! $\mathrm{Oh}$, there is naught in nature bright Where Roses do not shed their light ! When Morning paints the orient skies, Her fingers burn with roseate dyes, And when, at length, with pale decline, Its florid beauties fade and pine, Sweet as in youth, its balmy breath Diffuses odour e'en in death! $\mathrm{O}$, whence could such a plant have sprung? Attend-for thus the tale is sung:When humid from the silvery stream, Effusing beauty's warmest beam, Venus appeared in flushing hues, Mellowed by ocean's briny dews; When in the starry courts above, The pregnant brain of mighty Jove Disclosed the nymph of azure glanceThe nymph who shakes the martial lanceThen, then, in strange eventful hour, The earth produced an infant flower, Which sprung with blushing tinctures dressed, And wantoned o'er its parent breast. 
The gods beheld this brilliant birth, And hailed the Rose, the boon of earth! With nectar drops, a ruby tide, The sweetly orient buds they dyed, And bade them bloom the flowers divine, Of him who sheds the teeming vine; And bade them on the spangled thorn Expand their bosoms to the morn.

\section{THE ROSE'S ERRAND.}

C. MACKAY.

I SENT a message by the Rose That words could not convey; Sweet vows I never dared to breathe, And wishes pure as they;

A mute but tell-tale messenger, It could not do me wrong; But told the passion I concealed, And hopes I cherished long.

My Love received it with a smile, She read its thought and sighed, Then placed it on her happy breast, And wore it till it died.

Iminortal Rose! it could not die : The spirit which it bore,

Lives in her heart as first in mineA joy for evermore. 


\section{SENSITIVE PLANT. \\ (Bashful Love.)}

国

HIS delicate emblem of bashfulness is a member of the Mimosa family. In India it becomes a tail tree.

The old pastoral poet, W. Browne, alludes to its peculiarities thus :

"Look how the feeling-plant, which learned swains Relate to grow on the East Indian plains, Shrinks up his dainty leaves if any sand You throw thereon, or touch it with your hand."

Matthew Prior alludes to the diversity of opinion as tc what causes this phenomenon :

"Whence does it happen that the plant, which well We name the 'sensitive,' should move and feel? Whence know her leaves to answer her command, And with quick horror fly the neighbouring hand ?"

There is one most remarkable member of this extraordinary family, known as the "friendly-tree," which droops it branches whenever any person approaches it, seeming as if it saluted those who sought retreat beneat $l_{1}$ its sheltering boughs. Moore calls it

"That courteous tree. Which bows to all who seek its cannpy." . I 


\section{THE MIMOSA.}

DARIVIN.

WEAK, with nice sense, the chaste mimosa stands : From each rude touch withdraws her timid hands. Oft, as light clouds prass o'er the Summer's glade, Alarmed, she trembles at the moving shade, And feels alive through all her tender form The whispered murmurs of the gathering storm : Shuts her sweet eyelids to approaching night, And hails with freshened charms the rosy light.

\section{THE SENSITIVE PLANT.}

\section{SHELLEY.}

A Sensitrive Plant in a garden grew, And the young winds fed it with silver dew; And it opened its fan-like leaves to the light, And closed them beneath the kisses of night

And the spring arose on the garden fair, Like the spirit of love felt everywhere! And each flower and herb on earth's dark breast Rose from the dreams of its wintry rest.

But none ever trembled and panted with bliss In the garden, the field, or the wilderness, Like a doe in the noontide with love's sweet want, As the companionless Sensitive Plant.

The snowdrop, and then the violet, Arose from the ground with warm rain wet; And their breath was mixed with fresh odour, sent From the turf, like the voice and the instrument. 
Then the pied wind-flowers, and the tulip tall, And narcissi, the fairest among them allWho gaze on their eyes in the stream's recess, Till they die of their own dear loveliness!

And the naiad-like lily of the vale,

Whom youth makes so fair, and passion so pale, That the light of its tremulous bells is seen Through their pavilions of tender green;

And the hyacinth purple, and white, and blue, Which flung from its bells a sweet peal anew Of music so delicate, soft, and intense, It was felt like an odour within the sense;

And the rose like a nymph to the bath addrest, Which unveiled the depth of her glowing breast, Till, fold after fold, to the fainting air The soul of her beauty and love lay bare;

And the wand-like lily, which lifted up, As a Mænad, its moonlight-coloured cup, Till the fiery star, which is its eye, Gazed through clear dew on the tender sky;

And the jessamine faint, and the sweet tuberose, The siveetest flower for scent that blows! And all rare blossoms, from every clime, Grew in that garden in perfect prime.

And on the stream whose inconstant bosom Was prankt under boughs of embowering blussoru, With golden and green light, slanting through Their heaven of many a tangled hue, 
Broad water-lilies lay tremulously, And starry river-buds glimmered by, And around them the soft stream did glide and dance IVith a motion of sweet sound and radiance.

And the sinuous paths of lawn and moss, Which led through the garden along and acrossSome open at once to the sun and the breeze, Some lost aniong bowers of blossoming trees-

Were all paved with daisies and delicate bells As fair as the fabulous asphodels, And flowerets which drooping as day drooped too, Fell into pavilions, white, purple, and blue, To roof the glowworm from the evening dew.

And from this undefiled paradise The flowers (as an infant's awakening eyes Smile on its mother, whose singing sweet Can first lull, and at last must awaken it),

When heaven's blithe winds had unfolded them, As mine-lamps enkindle a hidden gem, Shone smiling to heaven, and every one Shared joy in the light of the gentle sun ;

For each one was interpenetrated With the light and the odour its neighbour shed, Like young lovers whom youth and love make dear; Wrapped and filled by their mutual atmosphere.

But the Sensitive Plant, which could give small fruit Of the love which it felt from the leaf to the root, Received more than all, it loved more than ever, Where none wanted but it, could belong to the giver, 
For the Sensitive Plant has no bright flower Radiance and odour are not its dower;

It loves, even like Love; its deep heart is full;

It desires what it has not, the beautiful!

The light winds which from unsustaining wings

Shed the music of many murmurings ;

The beams which dart from many a star

Of the flowers whose hues they bear afar;

The plumed insects swift and free, Like golden boats on a sunny sea, Laden with light and odour, which pass

Over the gleam of the living grass;

The unseen clouds of the dew, which lie Like fire in the flowers till the sun rides high, Then wander like spirits among the spheres, Each cloud faint with the fragrance it bears;

The quivering vapours of dim noontide, Which like a sea o'er the warm earth glide, In which every sound, and odour, and beam, Move, as reeds in a single stream;

Each and all like ministering angels were For the Sensitive Plant sweet joy to bear, Whilst the lagging hours of the day went by Like windless clouds o'er a tender sky.

And when evening descended from heaven above, And the earth was all rest, and the air was all love, And delight, though less bright, was far more deep, And the day's veil fell from the world of sleep; 
And the beasts, and the birds, and the insects were drowned

In an ocean of dreams without a sound;

Whose waves never mark, though they ever impress The light sand which paves it, consciousness;

(Only over head the sweet nightingale Ever sang more sweet as the day might fail, And snatches of its Elysian chant

Vere mixed with the dreams of the Sensitive Plant;)

The Sensitive Plant was the earliest Up-gathered into the bosom of rest; A sweet chili weary of its delight, The feeblest and yet the favourite, Cradled within the embrace of night.

THE FRIENDLY TREE TO THE TRAVELLER.

HAIL, traveller in our Eastern land! Beneath my boughs a shelter seek, By graceful drooping to the ground My hospitable wish they speak.

Come! and from fiery noontide sun Cool shade and refuge shall thou find; For feeling, near akin to man's, Is in my leafy heart enshrined.

I hail thee then! for Nature tells How blest are they who freely give; And tender sympathies with man In all my buds and blossoms live. 


\section{EVENING PRIMROSE. \\ (Silent Love.)}

"Love us as emblems, night's dewy flowers."-Mrs. Hemans.

$\mathrm{HE}$ evening primrose is dedicated by Roman

Catholics to St. Elizabeth, Queen of Portugal.

It has not elicited so many poetical addresses as its sister of the day, yet has not been quite overlooked. Keats mused thus on

"A tuft of evening primroses, O'er which the mind may hover till it dozes; O'er which it well night take a pleasant sleep, But that 'tis ever startled by the leap Of buds into ripe flowers."

THE EVENING PRIMROSE.

LANGHORNE.

There are that love the shades of life, And shun the splendid walks of fame;

There are that hold it rueful strife

To risk Ambition's losing game ;

That far from envy's lurid eye

The fairest fruits of genius rear,

Content to see them bloom and die

In friendship's small but kindly sphere 
Than vainer flowers, though sweeter far,

The Evening Primrose shuns the day;

Blooms only to the western star,

And love its solitary ray.

In Eden's vale an aged hind

At the dim twilight's closing hour,

On his time-smoothed staff reclined,

With wonder viewed the opening flower.

"Ill-fated flower, at eve to blow,"

(In pity's simple thought he cries,)

"Thy bosom must not feel the glow

Of splendid suns, or smiling skies.

"Nor thee the vagrants of the field,

The hamlet's little train behold;

Their eyes to sweet oppression yield,

When thine the falling shades unfold.

"Nor thee the hasty shepherd hecds,

When love has filled his heart with cares:

For flowers he rifles all the meads;

For waking flowers-but thine forbears.

"Ah! waste no more that beauteous bloom, On night's chill shade that fragrant breath;

Let smiling suns those gems illume!

Fair flower! to live unseen is death !"

Soft as the voice of vernal gales

That o'er the bending meadows blow, Or streams that steal through even vales, And murmur that they move so slow. 
Deep in her unfrequented bower, Sweet Philomela poured her strain;

The bird of eve approved her flower,

And answered thus the anxious swain :-

"Live unseen!

By moonlight shades, in valleys green, Lovely flower, we'll live unseen. Of our pleasures deem not lightly, Laughing day may look more sprightly;

But I love the modest mien,

Still I love the modest mien

Of gentle evening fair, and her star-trained quee

"Didst thou, shepherd, never find

Pleasure is of pensive kind!

Has thy cottage never known

That she loves to dwell alone?

Dost thou not at evening hour

Feel some soft and secret power

Gliding o'er thy yielding mind,

Leave sweet serenity behind,

While, all disarmed, the cares of day

Steal through the falling gloom away;

Love to think thy lot was laid

In this undistinguished shade;

Far from the world's infectious view

Thy little virtues safely blew?

Go, and in day's more dangerous hour,

Guard thy emblematic flower." 


\section{THE HELIOTROPE. \\ (Devoted Attachment.)}

HE Heliotrope divides with the Sunflower the fable of representing Clytie, who died of love for the sun, the course of which its flowers are supposed

to follow.

This is Ovid's* relation of her fate :

"She with distracted passion pines away;

Detcsteth company ; all night, all day

Disrobèd, with her ruffled hair unbound, And wet with humour, sits upon the ground :

For nine long days all sustenance forbears ;

Her hunger cloyed with dew, her thirst with tears :

Nor rose ; but rivets on the god her eyes,

And ever turns her face to him that flies.

At length to earth her stupid body cleaves;

Her wan complexion turns to bloodless leaves.

Yet streaked with red, her perished limbs beget

A flower rescmbling the pale violet,

Which with the sun, though rooted fast, doth move,

And being changèd, changeth not her love."

\section{THE HELIOTROPE.}

ANON.

There is a flower whose modest eye

Is turned with looks of light and love,

Who breathes her sweetest, softest sigh,

Whene'er the sun is bright above.

* Sandys's translation. 
Let clouds obscure, or darkness vell, Her fond idolatry is fled;

Her sighs no more their sweets exhale, The loving eye is cold and dead.

Canst thou not trace a moral here, False flatterer of the prosperous hour? Let but an adverse cloud appear, And thou art faithless as the flower.

\section{HELIOTROPE.}

SHE, enamoured of the sun, At his departure hangs her head and weeps, And shrouds her sweetness up, and keeps

Sad vigils like a cloistered nun, Till his reviving ray appears, Waking her beauty as he dries her tears.

\section{THE HELIOTROPE.}

PALE flower! the symbol of a faithful love,

Closing your buds, heedless of dew or air, If he is gone--your heavenly light above For whom alone you bloom so sweet and fair, Rest still in hope, and calm thy tender sorrow Thy sun will bless thy gaze upon the morrow. 


\title{
$S W E E T B R I A R$. \\ (I Wound to Heal.)
}

\begin{abstract}
E cannot undertake to explain why this singular (10) meaning has been given to Sweetbriar.

It is called by the older poets "Eglantine"-a name sometimes erroneously given to the Honeysuckle. The strong perfume of Sweetbriar in a bouquet kills the other flowers which form it.
\end{abstract}

\section{SWEETBR IA R.}

LEIGH HUNT.

WILD rose, sweetbriar, eglantine, All these pretty names are mine, And scent in every leaf is mine, And a leaf for all is mine, And the scent-oh that's divine! Happy-sweet, and pungent-fine, Pure as dew, and picked as wine.

As the rose in gardens dressed Is the lady self-possessed, I'm the lass in simple vest, The country lass whose blood's the best. 
Were the beams that thread the briar

In the morn with golden fire

Scented too, they'd smell like me,

All Elysian pungency.

\section{TO THE SWEETBRIAR.}

BRAINARD.

OUR sweet autumnal western-scented wind Robs of its odours none so sweet a flower, In all the blooming waste it left behind, As that sweetbriar yields it; and the shower Wets not a rose that buds in beauty's bower One half so lovely; yet it grows along The poor girl's pathway; by the poor man's door. Such are the simple folks it dwells among; And humble as the bud, so humble be the song.

I love it, for it takes its untouched stand Not in the vase that sculptors decorate; Its sweetness all is of my native land; And e'en its fragrant leaf has not its mate Among the perfumes which the rich and great Bring from the odours of the spicy East. You love your flowers and plants, and will you hate The little four-leaved rose that I love best, That freshest will awake, and sweetesis go to rest? 


\section{LADY FERN. \\ (Fascination.)}

\section{A D Y F E R N. \\ CALDER CAMPBELL.}

$F$ you would see the lady fern In all her graceful power,

Go look for her where woodlarks learn

Love-songs in a summer bower; Where not far off, nor yet close by,

A merry stream trips on,

Just near enow for an old inan's eye

To watch the waters run, And leap o'er many a cluster white

Of crowfoots o'er them spread; While hart's tongues quiet with a green more bright

Where the brackens make their bed.

Ferns all-and lovely all-yet each

Yielding in charms to her

Whose natural graces Art might teach

High lessons to confer.

Go look for the pimpernel by day,

For Selene's flowers by night,

For the first loves to bask in the sunny ray,

And the last woos the moon's soft light; 
But day or night the lady fern

May catch and charm your eye,

When the sun to gold her emerald turns,

Or the moon lends her silver dye.

But seek her not in early May,

For a Sibyl then she looks,

With wrinkled fronds that seem to say,

"Shut up my wizard books!"

Then searcli for her in the summer woods,

Where rills keep moist the ground,

Where foxgloves from their spotted hoods

Shake pilfering insects round;

Where up and clambering all about,

The traveller's joy flings forth

Its snowy awns, that in and out

Like feathers strew the earth.

Fair are the tufts of meadow sweet

That haply blossom nigh,

Fair are the whorls of violet

Prunella shows hard by;

But not by burn, in wood, or dale,

Grows anything so fair

As the plumy crest of emerald pale

That waves in the wind, or soughs in the gale.

Of the lady fern, when the sunbeams turn

To gold her delicate hair.

WALTER SCOTT.

WHERE the copse-wood is the greenest,

Where the fountain glistens sheenest,

Where the morning dew lies longest,

There the lady fern grows strongest. 


\section{$M Y R T L E$. \\ (Love.)}

Te $\mathrm{HE}$ Mrtle, like the rose, is generally considered symbolic of love, and by the Greeks and Romans was consecrated to Venus, round whose temples they planted groves of it ; and, when the votaries of this goddess sacrificed to her, they, like her attendant Graces, wore myrtle chaplets.

Thie Myrtle is supposed to derive its name from Myrsine, an Athenian maiden, and favourite of Minerva, said to have been metamorphosed into the myrtle; at any rate, it owes its origin to a Greek word signifying perflime.

Amongst the ancient writers who speak of its symbolism is Pliny: he records that the Romans and Sabines, when they were reconciled, laid down their weapons under a myrtle-tree, and purified themselves with its boughs. When Harmodius and Aristogiton set forth to free their country from a tyrant, their swords were wreather with myrtle.

I'll wreathe my sworl in myrtle boughs,

The sword that laid the tyrant low,

When patriots, burning to be free,

To Athens gave equality.-

GREEIS ANTHOLOGY. 


\section{A MYRTLE.}

KEATS.

A myrtle, fairer than

E'er grew in Paphos, from the bitter weeds Lifts its sweet head into the air, and feeds

A silent space with ever-sprouting green.

All tenderest birds there find a pleasant screen,

Creep through the shade with noisy fluttering,

Nibble the little cupped flowers, and sing.

\section{THEIR GROVES O' SWEET MYRTLE.}

EURNS.

Their groves o' sweet myrtle let foreign lands reckon

When bright beaming summers exalt the perfume;

Far dearer to me yon lone glen or green bracken, IVi' the burn stealing under the lang yellow broom

Far dearer to me all yon humble brown bowers, Where the bluebell and gowan lurk lowly unseen:

For there lightly tripping amang the wild flowers,

A-listening the linnet, aft wanders my Jean.

\section{THE MYRTLE BOUGH.}

Srill green! as when on holy ground The tyrant's blood was poured;

Forget ye not what garlands bound

The young deliverer's sword!

Though earth may shroud Hasmodius now

We still have sword and myrtle bough. 


\section{$\mathcal{F} A S M I N E$. (Amiability.)}

ANY significations are attached to this exquisitely scented flower, but the most reliable works adopt it as the representative of amiability.

\section{THE JASM I N E. \\ COWPER.}

THE jasmine throwing wide her elegant sweets, The deep dark green of whose unvarnished leaf Makes more conspicuous and illumines more The bright profusion of her scattered stars.

\section{TO A JASMINE TREE}

GROWING IN THE COURT OF NAWORTH CASTLE.

LORD MORPETH.

My slight and slender jasmine-tree, That bloomest on my Border-tower,

Thou art more dearly loved by me

Than all the wealth of fairy bower. 
I ask not, while I near thee dwell ; Arabia's spice or Syria's rose; Thy bright festoons more freshly smell, Thy virgin white more freshly glows.

My wild and winsome jasmine-tree, That climbest up the dark-grey wall, Thy tiny flowerets seem in glee, Like silver spray-drops down to fall: Say, did they from their leaves thus peep, When mailed moss-troopers rode the hill? When helmed wardens paced the keep, And bugles blew for Belted Will?

My free and feathery jasmine-tree, Within the fragrance of thy breath, Yon dungeon grated to its key, And the chained captive pined for death On Border fray, on feudal crime, I dream not while I gaze on thee; The chieftains of that stern old time Could ne'er have loved a jasmine-tree.

\section{JASMINE.} MOORE.

THE image of Love, that nightly flies To visit the bashful maid, Steals from the jasmine flower, that sighs Its soul like her in the shade. The dream of a future happier hour

That alights on misery's brow, Springs out of the silvery almond flower That blooms on a leafless bough. 


\section{NIGHT SCENTING JASMINE.}

\section{MOORE.}

Many a perfume breathed

From plants that wake when others sleep;

From timid jasmine-buds that keep

Their odour to themselves all day,

But when the sunlight dies away

Let the delicious secret ont

To every breeze that roams about.

\section{PERFUME OF JASMINE.}

CHURCHILL.

The jasmine, with which the queen of flowers,

To charm her god, adorns his favourite bowers;

Which brides, by the plain hand of neatness drest,Unenvied rival! -wear upon the breast;

Sweet as the incense of the morn, and chaste As the pure zone which circles Dian's waist.

\section{ON THE INDIAN-JASMINE FLOWER.} RYAN.

How lovelily the jasmine flower Blooms far from man's observing eyes: And having lived its little hour,

There withers, - there sequestered dies! Though faded, yet 'tis not forgot;

A rich perfume time cannot sever

Lingers in that unfriended spot, And decks the jasmine's grave for ever. 
Thus, thus should man who seeks to soar

On learning's wings to fame's bright sky,

Far from his fellows seek that lore,

Unheeded live, sequestered die.

Thus, like the jasmine, when he's Hed,

Fame's rich perfume will ever keep,

Lingering around the faded dead,

As saints that watch some infant's sleep.

\section{TO THE JESSAMINE.}

MISS JANE TAYLOR.

SWEET jessamine, long may thy elegant flower

Breathe fragrance and solace for me:

And long thy green sprigs cvershadow the bower

Devoted to friendship and thee.

The eye that was dazzled where lilies and roses

Their brilliant assemblage displayed, With grateful delight on thy verdure reposes,

A tranquil and delicate shade.

But ah! what dejection that foliage expresses

Which pensively droops on her breast !

The dew of the evening has laden her tresses,

And stands like a tear on her crest.

I'll watch by thy side through the gloom of the night

Impatient till morning appears :

No charm can awaken this heart to cielight,

My jasmine, while thou art in tears. 
But soon will the shadows of night be withdrawn, Which ever in mercy are given; And thou shalt be cheered by the light of the morn, And fanned by the breezes of heaven.

And still may thy tranquil and delicate shade Yield fragrance and solace to me; For though all the flowers in my garden should fade, My heart will repose upon thee.

\section{THE GOLDEN CHAMPACA (OR Champack).}

(I'ellow Oriental Fessamine.)

MOORE.

ThE maid of India, blest again to hold In her full lap the champack's leaves of gold, Thinks of the time when, by the Ganges' flood, Her little playmates scattered many a bud Upon her long black hair, with glassy gleam Just dripping from the consecrated stream. 


\section{POPPY. \\ (Consolation-Oblivion.)}

HE Poppy, Greek mythologists tell us, was created by Ceres whilst in search of her daughter Proserpine, as a soother of her grief. The pastoral poet,

William Browne, in his quaint phraseology, says :

"Sleep-bringing poppy, by the plowman late,

Not without eause, to Ceres eonseerate:

For being round and full at his half-birth,

It signified the perfect orb of earth ;

And by his inequalities when blowne,

The earth's low vales and higher hills were shorvne;

By multitude of grains it held within,

Of men and beasts the number noted bin.

Or since her danghter that she loved so well, By him that in the infernal shades does dwell,

Fairest Proserpina was rapt away,

And she in plaints the night, in tears the day,

Had long time spent; when no high power could give her

Any redresse, the poppy did relieve her :

For, eating of the seeds, they sleep procured,

And so beguiled those griefs she long endured."

\section{P O P P I ES.}

\section{LEIGH HUNT.}

WE are slumberous poppies,

Lords of Lethe downs,

Some awake and some asleep,

Sleeping in our crown. 
What perchance our dreams may know,

Let our serious beauty show.

Central depth of purple,

Leaves more bright than rose,

Who shall tell what brightest thought

Out of darkest grows;

Who through what funereal pain,

Souls to love and peace attain?

Visions aye are on us,

Unto eyes of power,

Pluto's always setting sun,

And Proserpine's bower;

There, like bees, the pale souls come

For our drink with drowsy hum.

Taste: ye mortals, also,

Milky-hearted we;

Taste, but with a reverent care ;

Active-patient be.

Too much gladness brings to gloom

Those who on the gods presume.

\section{THROUGH THE FIELDS.}

\section{WILLIAM SAWYER.}

Pleasant beneath this burning sky of June,

To tread the field-paths by these hedges gay,

With shining gorse and rosy-blossomed May,

To linger here, where in full blaze of noon, 
Under the quivering branches of the trees, 'The air is cool and fragrant, and the light

Comes greenly tempered to the aching sight;

Or to pass hence, and plunging to the knees

In a green meadow, wade to the full sea

Of flowering grasses, foaming as we go

With clustering daisies. Nought more sweet may be,

The while the skylark soars and sings, and lo!

The cuckoo, lone Narcissus of the woods,

Of his own name enamoured, still that name intrudes.

\section{POPPIES AND SLEEP.}

HORACE SMITH.

Gentle sleep!

Scatter thy drowsiest Poppies from above;

And in new dreams, not soon to vanish, bless

My senses with the sight of her I love.

\section{THE FLOWERS OF PROSERPINE.}

A. C. SIVINBURNE.

No growth of moor or coppice

No heather flower or vine,

But bloomless buds of poppies

Green grapes of Proserpine;

Pale beds of blowing rushes,

Where no leaf blooms or blushes

Save this whereout she crushes

For dead men deadly wine. 


\section{ORANGE-BLOSSOM.}

(Your purity equals your loveliness.)

RANGE-BLOSSOM is generally deemed typical of chastity. The practice of brides wearing a wreath of it on their wedding-day, though still retained in some countries, is not so fashionable here as formerly.

In his "Ode to Memory," Tennyson alludes to the custom of using these blossoms at nuptials thus :

"Like a bride of old In triumph led, With music and sweet showers Of festal flowers, Unto the dwelling she must sway."

\section{THE ORANGE-BLOSSOM.}

JUST then, beneath some orange-trees, Whose fruit and blossoms in the breeze

Were wantoning together, free, Like age at play with infancy. 


\section{THE ORANGE-TREE.}

\section{SPENSER.}

NexT thereunto did grow a goodly tree,

With branches broad dispread and body great,

Clothèd with leaves, that none the wood might see, And laden all with fruit, as thick as thick might be.

The fruit were golden apples glistering bright, That goodly was their glory to behold; On earth no better grew, nor living wight

E'er better saw, but they from hence* were sold, For those which Hercules, with conquest bold, Got from great Atlas' daughters, hence began, And planted there, did bring forth fruit of gold, And those with which th'Eubœan young man wan [won] Swift Atalanta, when, through craft, he her outran.

Here also sprang that goodly golden fruit

With which Acontius got his lover true, Whom he had long time sought with fruitless suit;

Here eke that famous golden apple grew,

The which among the gods false Até threw,

For which the Idæan ladies disagreed,

Till partial Paris deemed it Venus' due, And had [of her] fair Helen for his meed, That many noble Greeks and Trojans made to bleed.

* The garden of Proserpina. 


\section{TO THE HUMMING BIRD.}

CHARLOTTE SMITH.

THERE, lovely bee-bird! mayst thou rove Through spicy vale and citron grove, And woo and win thy fluttering love

With plume so bright;

There rapid fly, more heard than seen, 'Mid orange-boughs of polished green, With glowing fruit, and flowers between Of purest white.

\section{THE ORANGE-BOUGH.}

MRS. HEMANS.

$\mathrm{OH}$ ! bring me one sweet orange-bough, To fan my cheek, to cool my brow; One bough, with pearly blossoms dressed, And bind it, mother! on my breast!

Go seek the grove along the shore, Whose odours I must breathe no more, The grove where every scented tree Thrills to the deep voice of the sea.

Oh! Love's fond sighs, and fervent prayer, And wild farewell, are lingering there, Each leaf's light whisper hath a tone, My faint heart, even in death, would own.

Then bear me thence one bough, to shed Life's parting sweetness round my head, And bind it, mother! on my breast When I am laid in lonely rest. 


\section{ANEMONE. \\ (Withered Hopes-Forsaken.)}

HIS flower derives its name from anemos, the [. Greek word for wind, from thence came our poetical appellation of "the wind-flower." The ancients tell us that the Anemone was formerly a nymph beloved by Zephyr, and that Flora, jealous of her beauty, banished her from her Court, and finally transformed her into the flower that now bears her name. The more common myth is, that the anemone sprang trom the blood of Adonis, combined with the tears which Venus shed over his body. The Greek poet Bion, in his "Lament for Adonis," says :

"That wretched queen, Adonis bewailing,

For every drop of blood lets fall a tear;

Two blooming flowers the mingled streams disclose:

Anemone the tears; the blood, a rose."

\section{TO THE ANEMONE.}

MISS PRATT.

Flowers of the wild wood! your home is there,

'Mid all that is fragrant, all that is fair;

Where the wood-mouse makes his home in the earth;

Where gnat and butterfly have their birth; 
Where leaves are dancing over each flower,

Fanning it well in the noontide hour, And the breath of the wind is murmuring low, As branches are bending to and fro.

Sweet are the memories that ye bring Of the pleasant leafy woods of spring; Of the wild bee, so gladly humming, Joyous that earth's young flowers are coming; Of the nightingale and merry thrush, Cheerfully singing from every bush ; And the cuckoo's note, when the air is still, Heard far away on the distant hill.

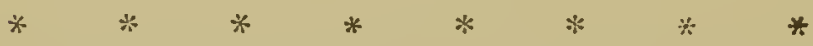

Pure are the sights and sounds of the wild Ye can bring to the heart of Nature's child; Plain and beautiful is the story That ye tell of your Maker's glory; Useful the lesson that ye bear, That fragile is all, however fair; While ye teach that time is on his wing, As ye open the blossoms of every spring.

\section{THE RED ANEMONE.}

TENNYSON.

GRowTHS of jasmine turned

Their humid arms, festooning tree and tree, And at the root through lush green grasses burned The red anemone. 


\section{ASPHODEL. \\ (I will be faithful unto Death.)}

9: NCIENTLY dedicated to the memory of departed souls, the asphodel is still very conmon in Greece; it was planted around the tombs of the deceased; and it was believed that beyond the fatal river Acheron, the shades wandered in a vast field of asphodels, and drank forgetfulness from Lethe's waters of oblivion. The flowers of the asphodel produce grains with which it was thought that the dead were nourished. Orpheus, in Pope's " Ode for St. Cecilia's Day," conjures the infernal deitjes:

"By the streams that ever flow, By the fragrant winds that blow O'er the Elysian flowers ; By those happy souls who dwell In yellow meads of asphodel Or amaranthine bowers."

We have as old an authority as Homer for stating that, after having crossed the Styx, the shades passed over a long plain of asphodels. Hence the meaning attached to the flower. 


\section{HONEYSUCKLE. \\ (Generons, denoted Affection.)}

7 HIS exquisite flower has something so homelike and English about it that we marvel it has not met with more poetical appreciation. All the glories of East and West cannot rival its blossoms in our estimation. Often in Eastern lands have we longer for the honeysuckle lanes of England. It grows (for the benefit of the wayfarer) in the hedgerow: it clasps the porch and thatch of the poor man's cottage: it wafts soothing perfume to the lover.

\section{THE HONEYSUCKLE.}

THE COUNTESS OF BLESSINGTON.

SEe the Honeysuckle twine

Round this casement :-'tis a shrine

Where the heart doth incense give,

And the pure affections live

In the mother's gentle breast

By her smiling infant pressed.

Blessed shrine! dear, blissful home! Source whence happiness doth come! 
Round by the cheerful hearth we meet All things beauteous - all things sweet Every solace of man's life, Mother-daughter-sister-wife!

England, Isle of free and brave, Circled by the Atlantic wave! Though we seek the fairest land That the south wind ever fanned, Yet we cannot hope to see Homes so holy as in thee.

As the tortoise turns its head Towards its native ocean-bed, Howsoever far it be From its own beloved sea, Thus, dear Albion, evermore Do we turn, to seek thy shore !

\section{FRAGMENT.}

SIR WALTER SCOTT.

AND well the lonely infant knew Recesses where the wallflower grew, And honeysuckle loved in crawl Up the low crag and ruined wall. I deemed such nooks the sweetest shade The sun in all his round surveyed, And still I thought that shattered tower The mightiest work of human power. 


\section{W O O D B I N E.}

SHAKSPEARE.

I kNow a bank whereon the wild thyme blows,

Where oxlips and the nodding violet grows;

Quite over-canopied with lush woodbine,

With sweet musk-roses, and with eglantine :

There sleeps Titania, some time of the night,

Lulled in these flowers with dances and delight:

And there the snake throws her enamelled skin,

Weed wide enough to wrap a fairy in.

\section{THE QUESTION.}

SHELLEY.

I DREAMED that, as I wandered by the way,

Bare winter suddenly was changed to spring,

And gentle odours led my steps astray,

Mixed with a sound of waters murmuring

Along a shelving bank of turf, which lay

Under a copse, and hardly dared to fling

Its green arms round the bosom of the stream,

But kissed it and then fled, as thou mightest in dream

There grew pied wind-flowers and violets,

Daisies, those pearled Arcturi of the earth, The constellated flower that never sets;

Faint oxlips; tender bluebells, at whose birth The sod scarce heaved; and that tall flower that wets Its mother's face with heaven-collected tears, When the low wind, its playmate's voice, it hears. 
And in the warm hedge grew lush eglantine,

Green cowbind and the moonlight-coloured May; And cherry blossoms, and white cups, whose wine

Was the bright dew yet drained not by the day ; And wild roses, and ivy serpentine,

With its dark buds and leaves, wandering astray, And flowers azure, black, and streaked with gold; Fairer than any wakened eyes behold.

And nearer to the river's trembling edge There grew broad flag-flowers, purple prankt with white And starry river buds among the sedge,

And floating water-lilies, broad and bright, Which lit the oak that overhung the hedge

With moonlight beams of their own watery light; And bulrushes and reeds of such deep green As soothed the dazzled eye with sober sheen.

Methought that of these visionary flowers

I made a nosegay, bound in such a way That the same hues which in their natural bowers

Were mingled or opposed, the like array Kept these imprisoned children of the hours Within my hand,--and then, elate and gay, I hastened to the spot whence I had come, That I might there present it !-oh! to whom?

\section{FROM THE "RAPE OF PROSERPINE."}

BARRY CORNWALL.

HeRE this rose

(This one half-blown) shall be my Maia's portion, For that like it her blush is beautiful: 
And this deep violet, almost as blue As Pallas' eye, or thine Lycinnia, I'll give to thee; for like thyself it wears

Its sweetness, ne'er obtruding. For this lily, Where can it hang but at Cyane's breast? And yet "twill wither on so white a bed, If flowers have sense, for envy :-It shall lie Amongst thy raven tresses, Cytheris, Like one star on the bosom of the night. The cowslip, and the yellow primrose, they Are gone, my sad Leontia, to their graves, And April hath wept o'er them, and the voice Of March hath sung, even before their deaths, The dirge of those young children of the year. But here is heart's-ease for your woes. And now, The honeysuckle flower I give to thee, And love it for my sake, my own Cyane: It hangs upon the stem it loves, as thou Hast clung to me, through every joy and sorrow ; It flourishes with its guardian's growth, as thou dost ; And if the woodman's axe should drop the tree, 'The woodbine too must perish.

\section{WREATHS.}

WEAVE thee a wreath of woodbine, child, 'Twill suit thy infant brow;

It runs up free in the woodlands wild, As tender and as frail as thou.

He bound his brow with a woodbine wreatll, And smiled his playful eye, And he lightly skipped o'er the blossomed heath, In his young heart's ecstacy. 
I saw him not till his manly brow Was clouded with thought and care, And the smile of youth, and its beauty, now No longer wantoned there.

Go, twine thee a crown of the ivy tree, And gladden thy loaded breast : Bright days may yet shine out for thee, And thy bosom again know rest.

Long years rolled on,--and I saw again His form in hoary age;

His forehead was deeply furrowed then, In life's last feeble stage.

$O$ be thy crown, old man, I said, Of the yew and the cypress made, A garland meet for thy silvered head Ere it low in the tomb be laid.

And such is Life, and such is Man

In his fleeting course below:

His little day, that in joy began, Must proceed and end in woe;

But another day shall weave for him

A garland that will not die, And his cup of bliss shall o'erflow its brim ;He shall live eternally.

\section{HONEYSUCKLES.}

KEATS.

Dew-SwEET eglantine, And honeysuckles full of clear bee-wine. 


\section{CELANDINE; \\ OR, \\ SIVALLOW HERB. \\ (Deceptive Hopes.)}

9 name from a Greek word signifying a swallow, because, say some, of its coming and going with that bird ; but according to Gerarde, it was so called from an opinion which prevailed among the country people, that the old swallows used it to restore sight to their young when their eyes were out.

\section{TO THE SMALL CELANDINE.}

\section{(COMMON PILE WORT.)}

WORDSWORTH.

Pansies, lilies, kingcups, daisies,

Let them iive upon their praises;

Long as there's a sun that sets,

Primroses will have their glory;

Long as there are violets,

They will have a place in story;

There's a flower that shall be mine.

"Tis the little Celandine. 
Eyes of some men travel far

For the finding of a star;

Up and down the heavens they go,

Men that keep a mighty rout;

I'm as great as they, I trow,

Since the day I found thee out,

Little flower-I'll make a stir

Like a sage astronomer.

Modest, yet withal an elf,

Bold, and lavish of thyself ;

Since we needs must first have met

I have seen thee, high and low,

Thirty years or more and yet,

'Twas a face I did not know;

Thou hast now, go where I may,

Fifty greetings in a day.

Ere a leaf is on a bush,

In the time before the thrush

Has a thought about her nest,

Thou wilt come with half a call,

Spreading out thy glossy breast

Like a careless Prodigal ;

Telling tales about the sun

When we've little warmth or none.

Poets, vain men in their mood,

Travel with the multitude;

Never heed them : I aver

That they all are wanton wooers;

But the thrifty cottager,

Who stirs little out of doors. 
Joys to spy thee near her lome: Spring is coming; thou art come

Comfort have thou of thy merit, Kindly unassuming spirit !

Careless of thy neighbourhood, Thou dost show thy pleasant face On the moor, and in the wood, In the lane; there's not a place Howsoever mean it be, But 'tis good enough for thee.

Ill befall the yellow flowers, Children of the flaring hours ! Buttercups that will be seen, Whether we will see or no; Others, too, of lofty mien, They have done as worldlings do, Taken praise that should be thine, Little, humble Celandine.

Prophet of delight and mirth, Ill reputed upon earth; Herald of a mighty band, Of a joyous train ensuing, Serving at my heart's command, Tasks that are no tasks renewing; I will sing, as doth behove, Iymns in praise of what I love ! 


\section{WEEPING WILLOW.}

(Mourning.)

IIS tree has ever been regarded as the symbol of (5orrow, and most appropriately, for not only do its pensive-looking branches droop mournfully towards the ground, but even very frequently little drops of water are to be seen standing, like tears, upon the pendent leaves. In its native East it is often planted over graves, and with its sorrowful, afflicted look, forms a most appropriate guardian of the departed ones' rest. "The famous and admired weeping willow:" says Martyn, "planted by Pope, which has since been felled to the ground, came from Spain, enclosing a present for Lady Suffolk. Pope was present when the covering was taken off ; he observed that the pieces of stick appeared as if they had some vegetation, and added, 'Perhaps they may produce something we have not in England.' Under this idea, he planted it in his garden, and it produced the willow-tree that has given birth to so many others."

\section{THE WILLOW.}

BYRON.

WE sat down and wept by the waters

Of Babel, and thought of the day 
When our foe, in the hue of his slaughters,

Made Salem's high places his prey; And ye, $\mathrm{O}$ her desolate daughters!

Were scattered all weeping away.

While sadly we gazed on the river, Which rolled on in freedom below, He demanded the song; but, oh, never That triumph the stranger shall know! May this right hand be withered for ever Ere it string our high harp for the foe !

On the willows that harp is suspended,

O Salem! Its sound should be free :

And the hour when thy glories were ended

But left me that token of thee;

And ne'er shall its soft note be blended

With the voice of the spoiler by me.

\section{WEARING THE WILLOW.}

PERCY'S REZIQUES.

IVilly-How now, shepherde, what meanes that?

Why that willowe in thy hat?

Why thy scarffes of red and yellowe

Turned to branches of green willowe?

Cuddy-They are changed, and so am I ;

Sorrowes live, but pleasures die :

Phillis hath forsaken mee,

Which makes me weare the willowe-tree.

Willy.-Shepherde, be advised by mee, Cast off grief and willowe-tree ; 
For thy grief brings her content :

She is pleased if thou lament.

Cuddy-Herdsman, I'll be ruled by thee,-

There liees grief and willowe-tree;

Henceforth I will do as they,

And love a new love every day.

\section{THE WILLOW.}

SHAKSPEARE.

My mother had a maid called Barbara :

She was in love; but he she loved proved mad, And did forsake her. She had a song of "Willow.' An old thing 'twas, but it expressed her fortune, And she died singing it.

\section{THE WILLOW.}

SHAKSPEARE.

THERE is a willow grows aslant the brook,

That shows his hoar leaves in the glassy stream;

There with fantastic garlands did she* come,

Of crow-flowers, nettles, daisies, and long purples,

That liberal shepherds give a grosser name,

But our cold maids do dead men's fingers call them ;

There on the pendent boughs her coronet weeds

Clambering to hang, an envious sliver broke;

When down her weedy trophies and herself

Fell in the weeping brook.

* Ophelia. 


\section{TO A WILLOIV 'TREE.}

HERRICK.

THOU art to all lost love the best, The only true plant found; Wherewith young men and maids distrest, And left of love, are crowned.

When once the lover's rose is dead, Or laid aside forlorn, Then willow garlands 'bout the head, Bedewed with tears, are worn.

When with neglect, the lover's bane,

Poor maids rewarded be;

For their love lost, their only gain

Is but a wreath from thee.

And underneath thy cooling shade,

When weary of the light,

The love-spent youth and love-sick maid

Come to weep out the night.

\section{THE GARLAND.}

MOORE.

A willow garland thou didst send, Perfumed, last day, to me ; Which did but only this portend:

I was forsook by thee. 
Since so it is, I'll tell thee what:

To-morrow thou shalt see

Me wear the willow; after that

To die upon the tree.

As beasts unto the altar go

With garlands dressed, so I

Will with my willow wreath also

Come forth and sweetly die.

\section{S O N N E T.}

GARCILASSO.

FOR Daphne's laurel Phœbus gave his voice :

The towering poplar charmed stern Hercules;

The myrtle sweet, whose gifted flowers rejoice

Young hearts in love, did most warm Venus please; The little green willow is my Fledri's choice:

She gathers it amidst a thousand trees. Thus laurel, poplar, and sweet myrtle now, Nhere'er it grows, shall to the willow bow.

\section{THE DROOPING WILLOW.}

\section{E. L.}

Green willow ! over whom the perilous blast Is sweeping roughly, thou dost seem to me The patient emblem of humility, Waiting in meekness till the storm be passed, Assured an hour of peace will come at last; That there will be for thee a calm bright day When the dark clouds are gatliered far away, 
How canst thou ever sorrow's emblems be?

Rather I deem thy slight and fragile form,

In mild endurance bending gracefully,

Is like the wounded heart, which 'mid the storm

Looks for the promised time which is to be,

In pious confidence. Oh! thou shouldst wave

Thy branches o'er the lowly martyr's grave.

\section{THE WILLOW.}

KEBLE.

SEE the soft green willow springing

Where the waters gently pass,

Every way her free arms flinging

O'er the moist and reedy grass;

Long ere winter blasts are fled,

See her tipjed with vernal red,

And her kindly flower displayed

Ere her leaf can cast a shade.

Though the rudest hand assail her,

Patiently she droops awhile,

But when showers and breezes hail her.

Wears again her willing smile.

Thus I learn Contentment's power

From the slighted willow bower-

Ready to give thanks, and live

On the least that Heaven may give. 


\section{$S U N F$ I. OWER.}

\section{(Findelity.)}

(2) the sunflower. That nymph had been beloved by Helios, but it was not long before he transferred his affections to Leucothoe, daughter of King Orchamus. When Clytie found herself unable to regain her lover, she informed the Persian monarch of his daughter's love affair, and he had the unfortunate girl entombed alive. Helios, enraged at the terrible tragedy, entirely forsook the nymph whose jealousy had caused it; and she, overwhelmed with grief, lay prone upon the earth for nine days and nights without any sustenance, her eyes continually following the course of her adored sun through the heavens. At last the gods, less pitiless than her former admirer, transformed her into a sunflower, and, as Ovid says :

"Still the loved object the fond leaves pursue, Still move their root, the moving sun to view."

Robert Browning thus alludes to the story of Rudèl, the ancient French poet, who adopted this splendid blossom as his emblem:

"I know a mount, the gracious sun perceives

First when he visits, last, too, when he leaves

The world ; and, vainly favoured, it repays

The day-long glory of his steadfast gaze 
By no change of its large calm front of snow. And underneath the mount a flower I know, He cannot have perceived, that changes ever At his approach ; and, in the lost endeavour To live his life, has parted, one by one, With all a flower's true graces, for the grace Of being but a foolish mimic sun, With ray-like florets round a disc-like face. Men nobly call by many a mame the mount, As over many a land of theirs its large Calm front of snow, like a triumphal targe, Is reared ; and still with old names fresh ones vie, Each to its proper praise and own account.

Men call the flower the sunflower, sportively."

\section{THE SUNFLOWER.}

THOMSON.

THE lofty follower of the sun,

Sad when he sets, shuts up her yellow leaves, Drooping all night, and, when he warm returns, Points her enamoured bosom to his ray.

\section{TO THE SUNFLCGWER.}

PRIDE of the garden, the beautcous, the regal. The crowned with a diadem burning in gold; Sultan of flowers, as the strong-pinioned eagle, And lord of the forest their wide empire hold.

I.et the Rose boast her fragrance, the soft gales perfuming: The tulip unfold all her fair hues to me: Yet though sweet be their perfume, their rainbow dyes blooming,

I turn. noble Sunflower, with more love to thee. 
There are some think thy stateliness haughty, disdaining,-

Thy heaven-seeking gaze has no charm for their eyes

"Tis because the pure spirit within thee that's reigning

Exalts thee above the vain pleasures they prize.

Emblem of constancy, whilst he is beaming,

For whom is thy passion so steadfast, so true ;

May we, who of faith and of love are aye dreaming,

Be taught to remember this lesson by you!

If on earth, like the Sunflower, our soul's best devotion Shall turn to the source of Truth's far-beaming rays ;

O how blest, how triumphant, shall be our emotion, When the bright "Sun of Righteousness" bursts on our gaze.

\section{THE SUNFLOWER.}

L. E. LANDON.

Look upon this flower!

It is the symbol of unhappy love;

'Tis sacred to the slighted Clytie.

See how it turns its bosom to the sun,

And when dark clouds conceal it, or when night

Is on the sky, mark how it folds its leaves,

And droops its head, and weeps sweet tears of dew,The constant sunflower. 


\section{THE SUNFLOWER.}

HOOD.

I IVILL not have the mad Clytie, Whose head's turned by the sun;

The tulip is a courtly quean,

Whom therefore I will shun;

The cowslip is a country wench,

The violet is a nun;-

But I will woo the dainty rose,

The queen of every one.

\section{SUNFLOWER.}

\section{SHELLEY.}

Light-EnChanted sunflower! Thou Who gazest ever true and tender On the sun's revolving splendour,

Follow not his faithless glance

With thy faded countenance ;

Nor teach my beating heart to fear,

If leaves can mourn without a tear,

How eyes must weep.

\section{CONSTANCY.}

MOORE.

$\mathrm{OH}$ the heart that once truly loves never forgets, But as truly loves on to the close ; As the sunflower turns on her god when he sets The same look that she turned when he rose. 


\section{REAL FAITH.}

REAL faith is like the sun's fair flower,

Which 'midst the clouds that shroud it, and the winds

That wave it to and fro, and all the change Of air, and earth, and sky, doth rear its head, And looketh up, still steadfast, to its Grd.

\section{THE SUNFLOWER.}

DARWIN.

The Sunflower, says Darwin,

Climbs the upland lawn,

And bows in homage to the rising dawn!

Imbibes with eagle eye the golden ray, And watches as it moves the orb of day.

OVID.

STrLl the loved object the fond leaves pursue; Still moves their root, the moving sun to view. 


\section{$L A U R E L . \quad B A Y$. \\ (Glory.) \\ (Fame.)}

"We crown with the laurel wreath

The hero-god, the soldier chief."-Eliza Cook.

"Sweet bay-tree, symbol of the song that dreaming poet sings."

IBID.

"The victor's garland, and the poet's crown."-W. BRowne.

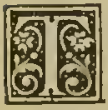

HE sweet bay was deemed by both Greeks and Romans emblematic of Victory and Clemency. The glories of all grand deeds were signalized by means of laurel crowns; its leaves were deemed very efficacious in the prevention of illness, and its shelter was believed to ward off lightning.

This presumed power is alluded to in the device of the Count de Dunois, which Madame de Genlis mentions as being a bay-tree, with the motto, "I defend the earth that bears me;" and Leigh Hunt, in his "Descent of Liberty," thus adverts to the belief :

"Long have you my laurels worn, And though some under-leaves be torn

Here and there, yet what remains

Still its pointed green retains,

And still an easy shade supplies

To your calnı-kept watchful eyes.

Only would you keep it hrightening

And its power to shake the lightning

Harmless down its glossy ears,

Suffer not so many years

To try what they can bend and spoil." 
The laurel bears the classic appellation of Daphne, because of the ancient legend connecting it with the nymph of that name, who, according to Ovid, was daughter of the river-god Peneus. Apollo beheld her, and at once became enamoured of her beauty; but Daphne fled from his importunities, and, fearful of being caught, called to Diana for assistance: she answered her prayers by transforming her into the laurel. Apullo, finding that he held nothing but a hard tree in his embrace, saluted its vivid green leaves with kisses, crowned his head with its leaves, and ordained that ever after that tree should be sacred to his godhead. Ovid thus recounts this fact:

"I espouse thee for my tree:

Be thou the prize of honour and renown;

The deathless poet and the poem crown.

Thou shalt the Roman festivals adorn,

And, after poets, be by victors worn."

Spenser resents the slight shown to the god of poetry, and thus vindictively speaks of the cold nymph:

"Proud Daphne, scorning Phøbus's lovely fire,

On the Thessalian shore from him did flee;

For which the gods, in their revongeful ire,

Did her transform into a laurel-tree."

Chaucer bestows the laurel upon the Knights of the Round Table, the Paladins of Charlemagne, and some other heroes of antiquity:

"That in their times did right worthily.

For one lefe given of that noble tree To any wight that hath done worthily Is more honour than anything erthly." 


\section{THE LAUREL.}

TASSO.

\section{O GLAD triumphal bough,}

That now adornest conquering chiefs, and now

Clippest the brows of overruling kings :

From victory to victory

Thus climbing on, through all the heights of story,

From worth to worth, and glory unto glory;

To finish all, $\mathrm{O}$ gentle and royal tree,

Thou reignest now upon that flourishing head, At whose triumphant eyes Love and our souls are led

\section{THE B A Y.}

E. COOK.

WHOM do we crown with the laurel-leaf?

The hero-god, the soldier chief;

But we dream of the crushing cannon-wheel,

Of the flying shot and the reeking steel,

Of the crimson plain where warm blood smokes,

Where clangour deafens and sulphur chokes;

Oh, who can love the laurel wreath,

Plucked from the gory field of death?

$$
\text { * * * * * }
$$

But there's a green and fragrant leaf

Betokens nor revelry, blood, nor grief;

'Tis the purest amaranth springing below,

And rests on the calmest, noblest brow.

It is not the right of the monarch or lord,

Nor purchased by gold, nor won by the sword;

For the lowliest temples gather a ray

Of quenchless light from the palm of bay. 
Oh, beautiful bay! I worship thee-

I homage thy wreath-I cherish thy tree;

And of all the chaplets Fame may deal

'Tis only to this one I would kneel.

For as Indian fly to the banian branch

When tempests lower and thunders launch,

So the spirit may turn from crowds and strife,

And seek from the bay-wreath joy and life.

\section{THE LAUREL.}

WORDSWORTE.

'Tis sung in ancient minstrelsy

That Phœbus wont to wear

The leaves of any pleasant tree

Around his golden hair,

Till Daphne, desperate with pursuit

Of his imperious love,

At her own prayer transformed, took root

A laurel in the grove.

Then did the penitent adorn

His brow with laurel green;

And 'mid his bright locks never shorn

No meaner leaf was seen;

And poets sage, in every age,

About their temples wound

The bay, and conquerors thanked the gods

With laurel chaplets crowned.

Into the mists of fabling tinie

So far runs back the praise

Of beauty, which disdains to climb

Along forbidden ways ; 
That scorns temptation, power defies,

Where mutual love is not;

And to the tomb for rescue flies

When life would be a blot.

\section{THE BAY. \\ WILLIAM BROWNE.}

Bays still grow, by lightning not struck downThe victor's garland and the poet's crown.

ANON.

O LAUREL Tree! long mayst thou crown The poet's brow with deathless fame; And all thy glossy leaves shower down.

\section{THE BAY TREE.}

ELIZA COOK.

THE bay tree is a bonny tree, but never is it known

'l'o flourish in the richest soil that holds the bay alone;

The bramble and the bitter leaf must fling their shadows nigh,

And then the bay tree rears its head and springs towards the sky. 


\section{PERIWINKLE.}

\section{(Tender Recollections.)}

France the Periwinkle, which there is sometimes called "the magician's violet," is considered the emblem of sincere friendship, and as such is much used in their language of flowers. The English have adopted this evergreen plant as the representative of tender recollections.

In Italy the country people make garlands of this plant, to place upon the biers of their deceased children, for which reason they name it the "flower of death." But in Germany it is the symbol of immortality; and, because its fine glossy myrtle-green leaves flourish all through the winter, they term it "winter verdure."

Chaucer repeatedly speaks of it in his "Romaunt of the Rose," even making it one of the ornaments of the God of Love :

"His garment was every dele

Ipurtraied and wrought with floures,

By divers medeling of coloures;

Floures there was of many a gise,

Iset by campace in a sise;

There lacked no floure to my dome,

$\mathrm{Ne}$ not so much as floure of brome,

$\mathrm{Ne}$ violet, ne eke perevink,

Ne floure none that men can on think." 


\section{WILD FLOWERS.}

\section{ANON.}

DESPISE thou not the wild flower-small it seem, And of neglected growth, and its light bells Hang carelessly on every passing gale; Yet it is finely wrought, and colours there Might shame the Tyrian purple, and it bears Marks of a care eternal and divine; Duly the dews descend to give it food, The sun revives its drooping, and the showers Add to its beauty, and the airs of Heaven Are round it for delight.

\section{FLOWERS.}

\section{BARRY CORNWALL.}

DEAR friend, love flower's well!

Flowers are the sign

Of Earth's all gentle love-her grace, her youth, Her endless, matchless, tender gratitude.

When the sun smiles on thee-why, thou art glad: But when on Earth he smileth, She bursts forth In beauty like a bride, and gives him back, In sweet repayment for his warm bright love, A world of flowers. You may see them born On any day in April, moist or dry, As bright as are the Heavens that look on them: Some sown like stars upon the greensward, some As yellow as the sunrise, others red As day is when he sets; reflecting thus In pretty moods the bounty of the sky. 


\section{DAHLIA.}

\section{(Instability and Pomp.)}

国 $\mathrm{HE}$ Dahlia is a native of Mexico, where Baron Humboldt found it growing in sandy meadows several hundred feet above the level of the sea. It was brought to England in 1789 , but was neglected and the genus lost. It ornamented the royal gardens of the Escurial, at Madrid, for several years before Spanish jealousy would permit it to be introduced into the other countries of Furope.

It derives its name from a countryman of the celebrated Linnæus, Professor Andrew Dahl, a Swedish botanist: he presented it in $\mathbf{1} 804$ to Lady Holland, who was its first successful English cultivator.

Its coarse foliage, gaudy flowers, and want of perfume seem to have prevented its becoming a favourite with our poets. Mrs. Sigourney just alludes to it as a florist's flower, in her "Farewell :"

"I have no stately dahlias, nor greenhouse flowers to weep,

But I passed the rich man's garden, and the mourning there was deep,

For the crownless queens all drooping hung amid the wasted sod, Lilie Boadicea, bent with shame beneath the Roman rod." 


\section{THE DAHIIA.}

\section{MARTIN.}

'ГHougr severed from its native clime, Where skies are ever bright and clear, And nature's face is all sublime, And beauty clothes the fragrant air,

The Dahlia will each glory wear, With tints as bright, and leaves as green; And winter in his savage mien,

May breathe forth storm,-yet she will bear With all :-and in the summer ray, With blossoms deck the brow of day.

And thus the soul-if fortune cast Its lot to live in scenes less bright, Should bloom amidst the adverse blast; Nor suffer sorrow's clouds to blight Its outward beauty - inward light. Thus should she live and flourish still, Though misery's frost might strive to kill The germ of hope within her quite :Thus should she hold each beauty fast, And bud and blosom to the last. 


\section{$M A R I G O L D$.}

\section{(Grief.)}

"She droops and mourns,

Bedewed, as 'twere with tears."

GEORGE WITHERS.

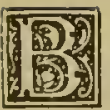

$Y$ old English poets these plants are called "golds "' the name of the Virgin Mary was a very frequent addition in the Middle Ages to anything useful or beautiful, and so in course of time this flower became known as the Marigold. In Provence they call it gauche fer (left-hand iron), probably from its round, brilliant disc, suggestive of a shield, which is worn on the left arm.

Although by itself, however, the Marigold expresses grief, by a judicious mixture with other flowers its meaning may be greatly varied. For instance, combined with roses it is symbolic of "the bitter sweets and pleasant pains of love ;" whilst amongst Eastern nations a bouquet of marigolds and poppies signifies "I will allay your pain." As. sociated with cypress, the emblem of death, marigolds betoken despair.

The marigold is usually open from nine in the morning till three in the afternoon; this foreshows a continuance of dry weather: should the blossom remain closed. rain may be expected. It shuts at sunset : 
"The Marybudde, that shutteth with the light."

Browne, in his "Britannia's Pastorals," says :

"But, maiden, see the day is waxen olde,

And 'gins to shut in with the marygolde."

Whilst Shakspeare says in "Cymbeline," that when "Phobus 'gins arise," the "winking marybuds begin to ope their golden eyes."

Keats pays more heed to the natural attractions of this flower and sings :

"Open afresh your round of starry folds,

Ye ardent marigolds!

Dry up the moisture of your golden lids,

For great Apollo bids

That in these days your praises shall be sung

On many harps, which he has lately strung;

And then again your dewiness he kisses-

Tell him I have you in my world of blisses :

So haply when I rove in some far vale,

His mighty voice may come upon the gale."

Chaucer calls the Marigold a "Golde," and makes a garland of them typical of jealousy, yellow being the emblematical colour of that passion.

\section{THE MARIGOLD.}

G. WITHERS.

WHEN with a serious musing, I behold

The grateful and obsequious Marigold,

How duly, every morning, she displays

Her open breast when Phœbus spreads his rays ;

How she observes him in his daily walk,

Still bending towards him her small slender stalk;

How, when he down declines, she droops and mourns,

Bedewed as 'twere with tears. till he returns; 
And how she veils her flowers when he is gone,

As if she scornèd to be looked upon

By an inferior eye ; or did contemn

To wait upon a meaner light than him:

When this I meditate, methinks the flowers

Have spirits far more generous than ours,

And give us fair examples to despise

The servile fawnings and idolatries

Wherewith we court these earthly things below,

Which merit not the service we bestow.

But Oh, my God! though grovelling I appear

Upon the ground, and have a rooting here

Which hales me downward, yet in my desire

To that which is above me I aspire,

And all my best affections I profess

To him that is the Sun of Righteousness.

Oh! keep the morning of his incarnation,

The burning noon-tide of his bitter passion,

The night of his descending, and the height.

Of his ascension,-ever in my sight,

That imitating Him in what I may,

I never follow an inferior way.

\title{
THE MARIGOLD.
}

\author{
SHAKESPEARE.
}

Here's flowers for you;

Hot lavender, mints, savory, marjoram;

The marigold, that goes to bed with the sun, And with him rises weeping. 


\section{THE LILY. \\ (Majesty and Purity.)}

HE Lily was sacred to Juno, and is now con. secrated to the Virgin Mary. It has inspired very lovely poetry.

\section{A BOUQUET OF LILIES.}

WORDSWORTH.

A LiLy flower,

The old Egyptian's emblematic mark

Of joy immortal and of pure affection.

\section{E. L.}

THE water lilies, that glide so pale,

As if with constant care

Of the treasures which they bear;

For those ivory vases hold

Each a sunny gift of gold.

COWLEY.

The virgin lilies in their white

Clad but with the lawn of almost naked white. 


\section{LILIES.}

\section{LEIGH HUNT.}

WE are lilies fair,

The flower of virgin light,

Nature held us forth, and said,

"Lo! my thoughts of white !"

Ever since then, angels

Hold us in their hands ;

You may see them where they take

In pictures their sweet stands.

Like the garden's angels

Also do we seem,

And not the less for being crowned

With a golden dream.

Could you see around us

The enamoured air,

You would see it pale with bliss

To hold a thing so fair.

\section{WATER LILIES.}

E. R. B.

Misty moonlight, faintly falling,

O'er the lake at eventide,

Shows a thousand gleaming lilies

On the rippling waters wide. 
White as snow, the circling petals

Cluster round each golden star,

Rising, falling with the waters,

Moving, vet at rest they are.

Winds may blow, and skies may darken,

Rain may pour, and waves may swell;

Deep beneath the changeful eddies

Lily roots are fastened well.

\section{THE CLOSING LILY.}

TENNYSON.

Now folds the lily all her sweetness up,

And slips into the bosom of the lake;

So fold thyself, my dearest, thou, and slip

Into my bosom, and be lost in me.

\section{A DIALOGUE FROM SOUL GARDENING.}

DORA GREENWELL.

"THou bearest flowers within Thy hand, Thou wearest on Thy breast

A flower; now tell me which of these Thy flowers Thou loveth best;

Which wilt Thou gather to Thy heart Beloved above the rest?"

"Should I not love my flowers, My flowers that bloom and pine, Unseen, unsought, unwatched for hours By any eyes but Mine? 
Should I not love my flowers ?

I love my Lilies tall,

My Marigold with constant eyes,

Each flower that blows, each flower that dies

To Me, I love them all.

I gather to a heavenly bower

My Roses fair and sweet;

I hide within my breast the flower

That grows beside my feet."

\section{UNE PENSEE.}

TOM HOOD.

"There's Pansies: that's for thoughts." - ShaksPeAre.

GAY lilies on the virgin breast

Of her who dieth young;

And o'er the warrior gone to rest

Let laurel wreaths be flung;

But strew ye purple pansies when the old man's knell is rung.

Fair types those lily flowers are

Of her for whom ye weep;

Whom earnest prayer and loving care

Could not among us keep;

But strew ye purple pansies when the old man falls asleep!

Well fitting for the warrior dead

The laurels he has won-

Proof of the brave life he has led,

The dangers he has run;

But stiew ye purple pansies when the old man's war is done! 
By all the glances backward cast

Along life's weary shore-

By all the memories of the past

That may return no more;

Oh, strew ye purple pansies when the old man's life is o'er!

\section{THE WATER IILY.}

J. H. REYNOLDS.

In a brook which loved to fret

O'er yellow sand and pebble blue,

The lily of the silvery hue

All freshly dwelt, with white leaves wet.

Away the sparkling water played,

Through bending grass, and blessed flower;

Light and delight seemed all its dower :

Away in merriment it strayed-

Singing, and bearing, hour after hour,

Pale lovely splendour to the shade.

THE STAR AND THE WATER-LILY.

OLIVER WENDELL HOLMES.

THE Sun stepped down from his golden throne, And lay in the silent sea,

And the Lily had folded her satin leaves.

For a sleepy thing was she.

What is the Lily dreaming of ?

Why crisp the waters blue?

See, see, she is lifting her varnished lid!

Her white leaves are glistening through ! 
The Rose is cooling his burning cheek

In the lap of the breathless tide ;-

The Lily hath sisters fresh and fair,

That would lie by the Rose's side ;

He would love her better than all the rest,

And he would be fond and true ;-

But the Lily unfolded her weary lids,

And looked at the sky so blue.

Remember, remember, thou silly one,

How fast will thy summer glide,

And wilt thou wither a virgin pale,

Or flourish a blooming bride?

" $\mathrm{O}$ the Rose is old, and thorny, and cold,

"And he lives on earth," said she;

"But the Star is fair, and he lives in the air,

And he shall my bridegroom be."

But what if the stormy cloud should come,

And ruffle the silver sea?

Would he turn his eye from the distant sky

To smile on a thing like thee ?

O no, fair Lily, he will not send

One ray from his far-off throne;

The winds shall blow, and the waves shall flow,

And thou wilt be left alone.

There is not a leaf on the mountain top,

Nor a drop of evening dew,

Nor a golden sand on the sparkling shore,

Nor a pearl in the waters blue, 
That he has not cheered with his fickle smile,

And warmed with his faithless beam,-

And will he be true to a pallid flower

That floats on the quiet stream?

Alas for the Lily! she would not heed,

But turned to the skies afar,

And bared her breast to the trembling ray

That shot from the rising Star;

The cloud came over the darkened sky,

And over the waters wide:

She looked in vain through the beating rain,

And sank in the stormy tide.

\section{THE WATER LILY.}

J. H. REYNOLDS.

O MELON-SCENTED lily!

O water queen of flowers!

When shall I see the silver waves

Dancing around thee, like sweet slaves

To Beauty in its bowers;

When shall I take an earthly part

In honouring thy golden heart?

O pretty rose autumnal!

$O$ fairy queen of trees!

When may I have thy gentle buds

Adorned with their emerald studs,

In their green palaces;

When see thy vernal velvet fall

Under thy ruby coronal? 
The sound of forest music

The water song of streams,

Are become dim and strange to me As musings of old witchery;

But in my fitful dreams,

And in my waking weary hours

Spirits come to me, as from flowers.

\section{LILIES.}

MRS. HEMANS.

THou bidd'st

The lilies of the field with placid smile Reprove man's feverish strivings, and infuse Through his warm soul a more unworldly life With their soft holy breath. Thou hast not left His purer nature, with its fine devices, Uncared for in this universe of Thine!

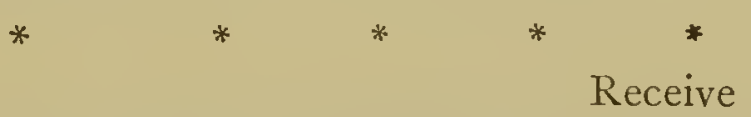

Thanks, blessings, love for these Thy lavish boons. And, most of all, their heavenward influences, O Thou, who gavest us flowers ! 


\title{
SWEET WILLIAM. \\ (Gallantry-Finesse.)
}

\begin{abstract}
囷 $\mathrm{HE}$ Srueet William, a member of the Pink family, from the charming manner in which it arranges its variegated blossoms into bouquet-shaped clusters, is well worthy of its second name of finesse.

The Bearded Pink, as it is sometimes designated, is known to our French neighbours as the "poet's eye," because of the manner in which its petals are marked.
\end{abstract}

\section{SWEET WILLIAM.}

\section{COWLEY.}

SweEt William small, has form and aspect bright, Like that sweet flower that yields great Jove delight Had he majestic bulk he'd now be styled Jove's flower; and, if my skill is not beguiled, He was Jove's flower when Jove was but a child. Take him with many flowers in one conferred, He's worthy Jove, ev'n now he has a beard. 


\section{THE GILLY FLOWER.}

DRAYTON.

THE curious choice clove July flower,

Whose kinds, hight the carnation, For sweetness of most sovereign power Shall help my wreath to fashion; Whose sundry colours of one kind, First from one root derived, Them in their several suits I'll bind, $\mathrm{My}$ garland so contrived.

\section{SWEET WILLIAM.}

SwEET little English flower, that bear'st The name our Shakspeare bore, Fashion has set thy claims aside;

So worthy deemed of yore!

In cottage garden only now, Sweet William, art thou found, Where southernwood and gilly flowers, And old-world buds abound. Alas! thy meaning too is changed,

It does not now express Man's gallantry, as once it did, But modern days' finesse. 


\section{FOXGLOVE.}

\section{(Insincerity.)}

1. HE Foxglone typifies insincerity because of the in vidious poison which lurks within its bright blossom. In France and Germany, and in some parts of England, it is known as "Fingerflower," because of the resemblance it bears to the finger of a glove, a resemblance which the poets have not failed to take advantage of. William Brown describes Pan as seeking gloves for his mistress :

"To keep her slender fingers from the sunne, Pan through the pastures oftentimes hath runne To pluck the speckled foxgloves from their stem, And on those fingers neatly placèd them."

\section{THE FOXGLOVE.}

ThE foxglove-leaves, with caution given, Another proof of favouring Heaven

Will happily display:

The rabid pulse it can abate,

The hectic flush can moderate, And, blest by Him whose will is fate,

May give a lengthened day. 


\section{FOXGLOVE.}

UPON the sunny bank

The foxglove rears its pyramid of bells,

Gloriously freckled, purpled and white, the flower That cheers Devonia's fields.

\section{W I L D FLOWERS.}

BARRY CORNWALL.

THE languid hyacinth and pale primrose,

And daisy trodden down like modesty;

The foxglove, in whose drooping bells the bee

Makes her sweet music.

\section{THE FOXGLOVE.}

COWLEY.

THE foxglove on fair Flora's hand is worn,

Lest, while she gather flowers, she meet a thorn.

BEEs, that soar for bloom, High as the highest peak of Furness Fells, Will murmur by the hour in foxglove bells. 


\section{FUCHSIA.}

(Taste.)

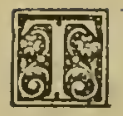

HE Fuchsia, a native of Chili, was named after Leonard Fuchs, a noted German botanist.

As it is quite a modern addition to our gardens, there is little poetry as yet belonging to it.

\section{THE FUCHSIA.}

ANON.

Beautiful child of a tropic sun,

How hast thou been from thy far home won,

To bloom in our chilly northern air,

Where the frost may blight, or the wind may tear?

Dost thou not pine for thine own dear land,

For its cloudless skies-for its zephyrs bland,

For its graceful flowers of matchless hues, Bright as the dreams of an Eastern muse?

Dost thou not pine for the perfumed air,

For the gorgeous birds that are hovering there;

For the starry skies, and the silver moon, And the grasshopper's shrill and unchanging tune? 
Doth thy modest head as meekly bend In thine own bright clime,--or doth exile lend To thy fragile stalk its drooping grace, Like the downcast look of a lovely face?

No! thou would'st murmur, were language thine, It is not for these I appear to pine ;

Nor for glorious flowers, nor cloudless skies,

Nor yet for the plumage of rainbow dyes.

The kindly care I have met with hereThe dew that is soft as affection's tear, Would have soothed, if sorrow had bent my head, And life and vigour around me shed.

But I do not pine, and I do not grieve, Why should I mourn for the things I leave?

I feel the sun and the gladsome air, And all places are joyous if they be there.

And thus in the world we may happy be, Not in climate, nor valley, nor islet free ; But wherever the tenderest love in our breast May have objects around it on which it can rest. 


\section{HEATH.}

(Solitude.)

\section{MOORLAND BLOSSOMS.}

ELIZA COOK.

70.0 ILD blossoms of the moorland, ye are very dear to me ;

Ye lure my dreaming memory as clover does the bee;

Ye bring back all my childhood loved, when freedom, joy and health

Had never thought of wearing chains to fetter fame and wealth.

Wild blossoms of the common land, brave tenants of the earth,

Your breathings were among the first that helped my spirit's birth;

For how my busy brain would dream, and how my heart would burn,

Where gorse and heather flung their arms above the forest fern.

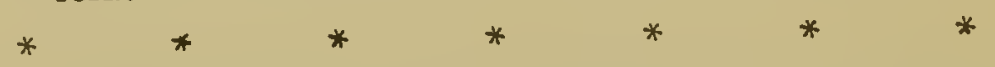

Who loved me then? Oh, those who were as gentle as sincere, 
Who never kissed my cheek so hard as when it owned a tear.

Whom did I love? Oh, those whose faith I never had to doubt;

Those who grew anxious at my sigh and smiled upon my pout.

What did I crave? The power to rove unquestioned at my will ;

Oh, wayward idler that I was!-perchance I am such still.

What did I fear? No chance or change, so that it did not turn

My footstep from the moorland coast, the heather, and the fern.

Methinks it was a pleasant time, those gipsy days of mine, When youth with rosy magic turned life's waters into wine; But nearly all who shared those days have passed away from earth,

Passed in their beauty and their prime, their happiness and mirth.

So now, rich flowerets of the waste, I'll sit and talk to ye, For memory's casket, filled with gems, is opened by your

key;

And glad I am that I can grasp your blossoms sweet and wild,

And find myself a doter yet, a dreamer, and a child.

\section{ON A SPRIG OF HEATH.}

\section{MRS. GRANT.}

FLOwER of the waste! the heath-fowl shuns

For thee the brake and tangled wood,- 
To thy protecting shade she runs, Thy tender buds supply her food; Her young forsake her downy plumes To rest upon thy opening blooms.

Flower of the desert though thou art! The deer that range the mountain free, The graceful doe, the stately hart, Their food or shelter seek from thee; The bee thy earliest blossom greets, And draws from thee her choicest sweets.

Gem of the heath! whose modest bloom Sheds beauty o'er the lonely moor; Though thou dispense no rich perfume,

Nor yet with splendid tints allure, Both valour's crest and beauty's power, Oft hast thou decked, a favourite flower.

Flower of the wild! whose purple glow Adorns the dusky mountain's side, Not the gay hues of Iris' bow,

Nor garden's artful, varied pride, With all its wealth of sweets could cheer, Like thee, the hardy mountaineer.

Flower of his heart! thy fragrance mild, Of peace and freedom seems to breathe:

To pluck thy blossoms in the wild, And deck his bonnet with the wreath, Where dwelt of old his rustic sires, Is all his simple wish requires.

Flower of his dear-loved native land! Alas, when distant, far more dear! 
When he from some cold foreign strand,

Looks homeward through the blinding tear,

How must his aching heart deplore

That home and thee he sees no more.

\section{H EA T H.}

How oft, though grass and moss are seen

'Tanned bright for want of showers,

Still keeps the ling its darksome green.

Thick set with little flowers.

\section{AUTUMN.}

T. HOOD.

THE Autumn skies are flushed with gold, And fair and bright the rivers rull; These are but streams of winter cold And painted mists that quench the sun

In secret boughs no sweet birds sing, In secret boughs no bird can shroud; These are but leaves that take to wing And wintry winds that pipe so loud.

'Tis not trees' shade, but cloudy glooms, That on the cheerless valley fall The flowers are in their grassy tombs, And tears of dew are on them all. 


\section{THE LILAC. \\ (The Joy of Youth.)}

NE of our sweetest spring flowers. It will not live long when separated from its parent tree.

\section{THE LILAC.}

THOMSON.

SHRUBS there are,

. . . That at the call of Spring

Burst forth in blossomed fragrance; lilacs, robed In snow-white innocence or purple pride.

\section{THE LILAC.}

THE lilac, various in array-now white, Now sanguine, and her beauteous head now set With purple spikes pyramidal ; as if, Studious of ornament, yet unresolved Which hues she most approves, she chose them all. 


\section{THE LILAC.}

MRS. SIGOURNEY.

Lilac of Persia! Tell us some fine tale Of Eastern lands ; we're fond of travellers. Have you no legends of some sultan proud, Or old fire-worshipper? What not one note Made on your voyage? Well, 'tis wondrous strange That you should let so rare a chance pass by, While those who never journeyed half so far Fill sundry volumes, and expect the world To reverently peruse and magnify What it well knew before!

\section{THE LILAC.}

BURNS.

$\mathrm{OH}$, were my love yon lilac fair

Wi' purple blossoms in the spring;

And I a bird to shelter there,

When wearied on my little wing.

How wad I mourn when it was torn

By autumn wild and winter rude!

But I wad sing on wanton wing,

When youthfu' May its bloom renewed. 


\section{LOTUS.}

(Eloquence-Repose.)

"The lotus-flower, whose leaves I now

Kiss silently,

Far more than words can tell thee, how

I. worship thee."---MOORE.

\section{THE LOTUS.}

TENNYSON.

OW sweet it were, hearing the downward stream

With half-shut eyes ever to seem

Falling asleep in a half dream !

To dream and dream, like yonder amber light,

Which will not leave the myrrh bush on the height;

To hear each other's whispered speech ;

Eating the Lotus, day by day,

To watch the crisping ripples on the beach,

And tender curving lines of creamy spray;

To lend our hearts and spirits wholly

To the influence of mild-minded melancholy;

To muse and brood and live again in memory,

With those old faces of our infancy

Heaped over with a mound of grass,

Two handfuls of white dust, shut in an urn of brass. 
The Lotus blooms below the flowery peak;

The Lotus blows by every winding creek;

All day the wind breathes low, with mellower tone;

Through every hollow cave and alley lone,

Round and round the spicy downs the yellow Lotus dust is blown.

We have had enough of action and of motion, we

Rolled to starboard, rolled to larboard, when the surge was seething free,

Where the wallowing monster spouted his foam fountains in the sea.

Let us swear an oath, and keep it with an equal mind,

In the hollow Lotus land to live and lie reclined

On the hills like gods together, careless of mankind;

For they lie beside their nectar, and the bolts are hurled

Far below them in the valleys, and the clouds are lightly curled

Round their golden houses, girdled with the gleaming world.

Surely, surely slumber is more sweet than toil ; the shore Than labour in the deep mid-ocean, wind and wave and oar ;

$\mathrm{O}$, rest ye, brother mariners; we will not wander more. 


\section{GENTIAN.}

(I love you best when you are sad.)

TO THE GENTIAN.

BRYANT.

闻 HOU blossom bright with autumn dew, And coloured with the heaven's own blue:

That openest when the quiet ligint Succeeds the keen and frosty night.

Thou comest not when violets lean O'er wandering brooks and springs unseen, Or columbines, in purple dressed, Nod o'er the ground-bird's hidden nest.

Thou waitest late and comest alone, When woods are bare and birds are flown, And frosts and shortening days portend The aged year is near his end.

Then doth thy sweet and quiet eye Look through its fringes to the sky, Blue-blue-as if that sky let fall A flower from its cerulean wall.

I would that thus, when I shall see The hour of death draw near to me, Hope blossoming within my heart, May look to heaven as I depart. 


\section{$S W E E T P E A S$.}

\section{(Delicate Pleasures.)}

97 $\mathrm{T}$ is singular that few of our poets have celebrated these exquisite flowers. These pretty lines of Keats exactly portray them:

"Here are sweet peas, on tiptoe for a flight;

With wings of gentle flush o'er delicate white, And taper fingers catching at all things, To bind them all about with tiny rings."

\section{TO THE SWEET PEA.}

Graceful flower, whose perfume lingers

On the sense with odours strange,

Climbing with thy fairy fingers

Where the sunbeams freely range;

Not the meanest aid disdaining

Which may help thee in thy flight

From the dull earth, upward straining

To the realms of purer light.

May we learn from thy sweet teaching

To aspire-to climb-to rise !

Ever, like thee, eager reaching

Hand and heart unto the skies. 


\section{$I V Y$ \\ (Friendship.)}

OORE says :

"When the ivy of friendship is green in our souls."

Dickens assumes the same meaning.

\section{THE IVY GREEN.}

C. DICKENS.

$\mathrm{OH}$, a dainty plant is the ivy green, That creepeth o'er ruins old;

Of right choice food are his meals, I ween,

In his cell so lone and cold.

The walls must be crumbled, the stones decayed,

To pleasure his dainty whim ;

And the mouldering dust that years have made

Is a merry meal for him.

Creeping where no life is seen,

A rare old plant is the ivy green.

Fast he stealeth on, though he wears no wings,

And a staunch old heart has he:

How closely he twineth, how tight he clings

To his friend, the lugge oak-tree! 
And slily he traileth along the ground,

And his leaves he gently waves,

And he joyously twines and hugs around

The rich mould of dead men's graves.

Creeping where no life is seen,

A rare old plant is the ivy green.

Whole ages have fled, and their works decayed,

And nations scattered been,

But the stout old ivy shall never fade,

From its hale and hearty green.

The brave old plant in its lonely days

Shall fatten upon the past,

For the stateliest building man can raise

Is the ivy's food at last.

Creeping where no life is seen,

A rare old plant is the ivy green.

IVY.

CALDER CAMPBELL.

$\mathrm{OH}$, falsely they accuse me,

Who say I seek to check

The growing sapling's flourishing;-

I better love to deck

The dead and dying branches

With all my living leaves,

"Tis for the old and withered tree

The Ivy garlands weaves. 


\section{GROUND IVY.}

AND there upon the sod below

Ground Ivy's purple blossoms show,

Iike helmet of crusader knight

In anther's cross-like form of white.

\section{THE IVY IN THE DUNGEON.}

CHARLES MACKAY.

THE Ivy in a dungeon grew,

Unfed by rain, uncheered by dew;

Its pallid leaflets only drank

Cave moistures foul, and odours rank.

But through the dungeon-grating high

There fell a sunbeam from the sky;

It slept upon the grateful floor,

In silent gladness evermore.

The Ivy felt a tremor shoot

Through all its fibres to the root:

It felt the light, it saw the ray,

It strove to blossom into day.

It grew, it crept, it pushed, it clomb-

Long had the darkness been its home,

But well it knew, though veiled in night,

The goodness and the joy of light.

Its clinging roots grew deep and strong;

Its stem expanded firm and long; 
And in the currents of the air

Its tender branches flourished fair.

It reached the beam-it thrilled-it curled-

It blessed the warmth that cheers the world!

It rose towards the dungeon bars-

It looked upon the sun and stars.

It felt the life of bursting Spring,

It heard the happy skylark sing;

It caught the breath of morns and eves,

And wooed the swallow to its leaves.

By rains and dews, and sunshine fed,

Over the outer wall it spread;

And in the daybeam, waving free,

It grew into a steadfast tree.

Upon that solitary place

Its verdure threw adoming grace:

The mating birds became its guests,

And sang its praises from their nests.

Would'st know the moral of the rhyme?

Behold the heavenly light, and climb-

To every dungeon comes a ray

Of God's interminable day.

\section{T H E I V Y。}

\section{BARTON.}

HAST thou seen, in winter's stormiest day, The trunk of a blighted oak, Not dead, but sinking in slow decay

Beneath time's resistless stroke, 
Round which a luxuriant ivy had grown, And wreathed it with verdure no longer its own?

Perchance thou hast seen this sight, and then, As I at thy years might do,

Passed carelessly by, nor turned again

That scathed wreck to view.

But now I can draw from that mouldering tree Thoughts which are soothing and dear to me.

O smile not! nor think it a worthless thing, If it be with instruction fraught;

That which will closest and longest cling

Is alone worth a serious thought! Should aught be unlovely which thus can shed Grace on the dying, and leaves on the dear?

\section{THE IVY.}

MRS. HEM A NS.

$\mathrm{OH}$ ! how could fancy crown thee In ancient days the god of wine, And bid thee at the banquet be

Companion of the vine.

Ivy! thy home is where each sound

Of revelry hath long been o'er; Where song and beaker once went round,

But now are known no more.

Where long fallen gods recline,

There the place is thine. 


\section{A MARANTH.}

\section{(Immortality.)}

"Immortal amaranth."-MiLToN.

OST poetical of all flowers in meaning is the Amaranth. It has been selected as the symbol of immortality, and has ever been associated with Death as the portal through which the soul must pass to Eternity. Milton gives crowns of amaranth to the angelic multitude assembled before the Deity:

"To the ground

With solemn adoration down they cast

Their crowns inwove with amaranth and gold.

Inimortal amaranth-a flower which once

In Paradise, fast by the tree of life,

Began to bloom : but soon for man's offence

To heaven removed, where first it grew, there grows

And flowers aloft, shading the fount of life,

And where the river of bliss, through midst of heaven

Rolls o'er Elysian flowers her amber stream :

With these that never fade the spirits elect

Bind their resplendent locks enwreathed with beams;

Now in loose garlands thick thrown off, the bright

Pavement, that like a sea of jasper shone,

Impurpled with celestial rosy smile."

'These flowers if gathered and dried will long preserve their beauty.

One of the most popular species of the amaranth is the "Love-lies-bleeding." The origin of this singular appellation is not known, but it has been suggested that the 
following verses of Campbell account for it. The daughter of O'Connor is lamenting over the tomb of Connocht Moran :

"A hero's bride? this desert bower, It ill befits thy gentle breeding :

And wherefore dost thou love this flower

To call 'My-love-lies-bleeding '?

"This purple flower my tears have nursed;

A hero's blood supplied its bloom :

I love it, for it was the first

That grew on Connocht Moran's tomb."

\section{THE AMARANTH.}

SHELLEY.

WHose sad inhabitants each year would come

With willing steps, climbing that rugged height

And hang long locks of hair, and garlands bound

With amaranth flowers, which, in the clime's despite,

Filled the frore air with unaccustomed light.

Such flowers as in the wintry memory bloom

Of one friend left, adorned that frozen tomb.

\section{LOVE LIES BLEEDING.}

WORDSWORTH.

THis flower, that first appeared as Summer's guest,

Reserves her beauty 'mid autumnal leaves,

And to her mournful habits fondly cleaves,

When files of stateliest plants have ceased to bloom,

One after one submitting to their doom,

When her coevals, each and all, are fled. 


\section{$A S P E N$.}

\section{(Lamentation.)}

"And full of emotion, its fault doth deplore, Sigh, shiver, and quiver, and droop evermore."

ELEANOR DARBY.

HE Trembling Poplar is now generally known as the Aspen. It is chiefly remarkable for the ceaseless tremulous motion of its leaves-a natural phenomenon, to account for which many very diverse explanations have been proffered. Miss Darby, in her "Lays of Love and Heroism," has thus versified a German legend upon the subject :

"The Lord of Life walked in the forest one morn, When the song-ivearied nightingale slept on the thorn; Not a breath the deep hush of the dawning hour brokc, Yet every tree, even the firm knotted oak, The tall warrior pine, and the eedar so regal, The home of the stork and the haunt of the eagle, All the patriarehal kings of the forest adored, And bowed their proud heads at the sight of the Lord.

"One tree, and one only, continued ereet, Too vain to show even the Saviour respect ! The light giddy aspen its leafy front raised, And on the Redeemer unbendingly gazed. Then a eloud, more of sorrow than wrath, dimmed the brow rif Him to whom everything living should bow ; While to the offender, with shame now opprest, He breathed in these words the etermal behest: 
" Alas for thy fate! thou must suffer, poor tree,

For standing when others were bending the knee.

Thou'rt doomed for thy fault an atonement to pay:

Heneeforth be a rush for the wild winds to sway.

Sigh, sport of their fury, and slave of their will!

Bow, e'en in a ealm, when all others are still !

And shivering, quivering, droop evermore,

Because thou wouldst not with thy brothers adore.'

"The weak aspen trembled, turned pale with dismay,

And is pallid with terror and grief to this day.

Each tremulous leaf of the penitent tree

Obeys to this moment the heavenly decree.

'Tis the sport of the wild winds, the slave of their will, E'en without a breeze bends, when all others stand still;

And full of emotion, its fault doth deplore,

Sigh, shiver, and quiver, and droop evermore."

\section{THE ASPEN-TREE.}

\section{CHARLES SWAIN.}

Why tremblest thoi, Aspen? no storm threatens nigh;

Not a cloud mars the peace of the love-beaming sky;

'Tis the spring of thy being-no autumn is near

Thy green boughs to wither, thy sweet leaves to sear !

The sun, like a crown, o'er thy young head shines free, Then wherefore thus troubled? what fearest thou, fair tree?

I have watched through the mildest, the stillest of hours, When Nature slept soft on her pillow of flowers;

When, though all things appeared 'neath her influcuce. blest,

Thou alone wert disturbed, thou alone couldst not rest! But still, as lamenting some dreadful decree, Thou groanedst in the calm, like an outcast, lone tree! 
A voice from its leaves seemed to wail on mine ear, "List, mortal ; attend the dark source of my fear ; Ah, learn the dread hour when we sank 'neath rebuke, And our boughs, as if grasped by a hurricane, shook! When the morn rose in blood, when the dead wept around,

And a curse 'gainst our seed burst in woe from the ground !-

"The Cross, amidst lightning on Calvary stained,

Was made from our roots; there His blood hath remained!

Creation, accursing, in misery spoke, And a shudder eternal then first o'er us broke ! From the serpent were named, the last doomed to betray! Oh! no rest for the Aspen till earth fades away!"

\section{THE A S E N.}

MRS. HEMANS.

THE blessed cross whereon

The meek Redeemer bowed His head to death Was framed of aspen wood; and since that lour Through all its race the pale tree hath sent down

A thrilling consciousness, a secret awe, Making them tremulous when not a breeze Disturbs the thistle-down. 


\section{CORNFLOWER.}

\section{(Delicacy.)}

"Now, gentle flower, I pray thee tell

If my lover loves me, and loves me well."

ANONYMOUS.

HE classic name of the bright blue Cornflower is

Cyanus; and it was so named after a worshipper of Flora, who made garlands for public festivities out of various sorts of wild flowers, and who lingered from morn till eve amid the corn weaving the blossoms that she had collected. Its petals are used for divination, as the thistle-down is.

This flower, although now so common in our cornfields, is thought not to be indigenous, but to have been brought from the East amongst some imported grain.

Its deep blue hue is so deep that it almost approaches a purple, and as such the poet addresses it:

"There is a flower, a purple flower, Sown by the wind, nursed by the shower, O'er which Love breathed a powerful spell, The truth of whispering hope to tell. Now, gentle flower, I pray thee tell If my lover loves me, and loves me well: So may the fall of the morning dew Keep the sun from fading thy tender blue." 


\section{FIELD FLOIVERS.}

\section{CAM PBELL.}

YE field flowers! the gardens eclipse you, 'tis true,

Yet, wildlings of nature, I dote upon you;

For ye waft me to summers of old,

When the earth teemed around me with fairy delight, And when daisies and buttercups gladdenerl my sight,

Like treasures of silver and gold.

I love you for lulling me back into dreams, Of the blue Highland mountains and echoing streams,

And of birchen glades breathing their balm;

While the deer was seen glancing in sunshine remote, And the deep mellow crush of the wood-pigeon's note

Made music that sweetened the calm.

Not a pastoral song has a pleasanter tune

Than ye speak to my heart, little wildlings of June ;

Of old ruinous castles ye tell:

I thought it delightful your beauties to find

When the magic of nature first breathed on my mind, And your blossoms were part of her spell.

Even now what affections the violet awakes!

What loved little islands, twice seen in her lakes,

Can the wild water-lily restore.

What landscapes I read in the primrose's looks, What pictures of pebbled and minnowy brooks,

In the vetches that tangle the shore! 
Earth's cultureless buds! to my heart ye were dear Ere the fever of passion, or ague of fear, Had scathed my existence's bloom;

Once I welcome you more, in life's passionless stage, With the visions of youth to revisit my age, And I wish you to grow on my tomb.

\section{F L O W E R S. \\ LONGFELLOW.}

IN all places, then, and in all seasons,

Flowers expand their light and soul-like wings,

Teaching us by most persuasive reasons How akin they are to human things; And with child-like, credulous affection We behold their tender buds expand, Emblems of our own great resurrectionFmblems of the bright and better lard. 


\section{CYPRESS.}

\section{(Mourning.)}

"The cypress is the emblem of mourning."-ShaKSPEARr

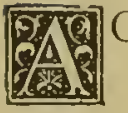

CCORDING to Ovid, this tree was named after Cyparissus, an especial favourite of Apollo. He had accidentally slain his pet stag, and was so sorrow-stricken that he besought the gods to doom his life to everlasting gloom; and they in compliance with his request, transformed him into a cypress-tree.

"When, lost in tears, the blood his veins forsakes,

His every limb a grassy hue partakes;

His flowing tresses, stiff and bushy grown,

Point to the stars, and taper to a cone,

Apollo thus: 'Ah! youth, beloved in vain,

Long shall thy boughs the gloom I feel retain :

Henceforth, when mourners grieve, their grief to share,

Emblem of woe the cypress shall be there."

\section{THE CYPRESS WREATH.}

SIR W. SCOTT.

O LADY, twine no wreath for me,

Or twine it of the cypress-tree!

Too lively glow the lilies light,

The varnished holly's all too bright,

The iNay-flower and the eglantine

May shade a brow less sad than mine;

But, lady, weave no wreath for me,

Or weave it of the cypress-tree. 
Let dimpled Mirth his temples twine

With tendrils of the laughing vine;

The manly oak, the pensive yew,

To patriot and to sage be due;

The myrtle bough bids lovers live,

But that Matilda will not give;

Then, lady, twine no wreath for me,

Or twine it of the cypress-tree.

Let merry England proudly rear

Her blended roses, bought so dear ;

Let Albin bind her bonnet blue

With heath and harebell dipped in dew ;

On favoured Erin's crest be seen

The flower she loves of emerald green-

But, lady, twine no wreath for me,

Or twine it of the cypress-tree.

Strike the wild harp, while maids prepare

The ivy meet for minstrel's hair;

And while his crown of laurel leaves

With bloody hand the victor weavcs,

I.et the loud trump his triumph tell;

But when you hear the passing bell,

Then, lady, twine a wreath for me,

And twine it of the cypress-tree.

Yes! twine for me the cypress bough;

But, O Matilda, twine not now!

Stay till a few brief months are past,

And I have looked and loved my last :

When villagers my shroud bestrew

With pansies, rosemary, and rue,-

Then, lady, weave a wreath for me,

And weave it of the cypress-tree. 


\section{THE CYPRESS-TREE.}

BLACKWOOD'S MAGAZINE.

A SLENDER tree upon a height in lonely beauty towers, So dark, as if it only drank the rushing thunder showers ; When birds were at their evening hymns, in thoughtful reverie,

I've marked the shadows deep and long, from yonder cypress-tree.

I've thought of oriental tombs, of silent cities, where

In many a row the cypress stands, in token of despair!

And thought, beneath the evening star, how many a maiden crept

From life's discordant scene, and o'er the tomb in silence wept.

I've thought, thou lonely cypress-tree, thou hermit of the grove,

How many a heart, alas! is doomed forlorn on earth to rove ;

When all that charmed the morn of life, and cheered the youthful mind,

Have like the sunbeams passed away, and left but clouds behind !

Thou wert a token unto me, thou stem with dreary leaf, So desolate thou look'st, as earth were but a home of grief!

A few short years shall swiftly glide, and then thy boughs shall wave,

When tempests beat, and breezes sigh, above my silent grave I 


\section{THISTLE.}

\section{(Independence.)}

"The thistle shall bloom on the bed of the brave."-ANon.

S the national emblem of Scotland the Thistle has been celebrated, far and wide, by the many bards of its brave people. There is some little doubt as to how this flower was first adopted oy the Scots. Some patriotic authors go back to the days of the Picts in order to trace the origin of its use, and adduce a romantic legend in proof of the antiquity of the custom. Be this as it may, the Plantagenets were not prouder of the broom than were the Stuarts of their thistle; and princes of the royal house were wont to wear the Cluas-au-pheidh, as it is called in Gaelic, with all the respect that its presumed antique and honourable history entitled it to. The poets of Scotland are ever ready to pay it homage, and the following thoroughly characteristic poem, to be found in Hogg's 'Jacobite Relics,' is supposed to have been written by the Ettrick Shepherd himself :

" 'Let them boast of the country gave Patrick his fame,

Of the land of the ocean and Anglian name,

With the red blushing roses and shamrock so green;

Far dearer to me are the hills of the North,

The land of blue mountains, the birthplace of worth ;

Those mountains where Freedom has fixed her abode,

Those wide-spreading glens where no slave ever trode,

Where blooms the red heather and thistle so green. 
" "Though rich be the soil where blossoms the rose, And barren the mountains and covered with snows

Where blooms the red heather and thistle so green ,

Yet for friendship sincere, and for loyalty true, And for courage so bold which no foe could subdue, Unmatched is our country, unrivalled our swains, And lovely and true are the nymphs on our plains,

Where rises the thistle, the thistle so green.

- Far-famed are our sires in the battles of yore, And many the cairnies that rise on our shore

O'er the foes of the land of the thistle so green; And many a cairnie shall rise on our strand, Should the torrent of war ever burst on our land. Let foe come on foe, as wave comes on wave, We'll give them a welcome, we'll give them a grave Beneath the red hcather and thistle so green.

" Oh, dear to our souls as the blessings of Heaven Is the freedom we boast, is the land that we live in, The land of red heather, and thistle so green; For that land and that freedom our fathers have bled, And we swear by the blood that our fathers have shed, No foot of a foe shall e'er tread on their grave ; But the thistle shall bloom on the bed of the brave, The thistle of Scotland, the thistle so green.'

"There appears to be no proof of this sturdy flower having been adopted as the symbol of Scotland earlier than the middle of the fifteenth century, when a puritanic council held a solemn consultation within the walls of the old Council-house at Edinburgh as to the advisability of erasing the papistic figure of St. Giles-which for so many centuries had been triumphantly borne through the battle and the breeze-from the old standard: religious animosity gained the day, and the time-honoured figure of the saint was replaced by the thistle."-J. InGRam. 


\section{$C L O V E R$ \\ OR,}

\section{SHAMROCK.}

(I promise.)

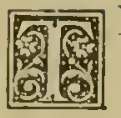

HE white Clover, or Shamrock, is the national emblem of Ireland, and claims an equal place in history with England's rose or Scotland's thistle. This symbol of their country is worn by Irishmen on the anniversary and in commemoration of St. Patrick's landing near Wicklow, in the beginning of the fourth century of the Christian era. The patron saint is reported to have explained to his disciples the mysteries of the Trinity by means of a clover-leaf, or trefoil.

"Brave sons of Hibernia, your shamrocks display, For ever made sacred on St. Patrick's day;

'Tis a type of religion, the badge of our saint, And a plant of that soil which no venom can taint.

"Both Venus and Mars to that land lay a claim, Their title is owned and recorded by fame ; But St. Patrick to friendship has hallowed the ground, And made hospitality ever abound.

"Then with sbamrocks and myrtles let's garnish the bowl, In converse convivial and sweet flow of soul; To our saint make oblations of generous wineWhat saint could have more?-sure, 'tis worship divine ! 
' Tho' jovial and festive in seeming excess, We've hearts sympathetic of others' distress. May our shamrocks continue to flourish, and prove An emblem of charity, friendship, and love.

"May the blights of disunion no longer remain,

Our shamrock to wither, its glories to stain; May it flourish for ever, we Heaven invoke,

Kindly sheltered and fenced by the brave Irish oak!"

Bees delight in the sweet-scented blossoms of what Tennyson aptly calls the

"Rare "broidery of the purple clover."

Walter Thornbury has given us the following pretty lyric, "In Clover :"

"There is clover, honey-sweet, Thick and tangled at our feet ; Crimson-spotted lies the field, As in fight the warrior's shield: Yonder poppies, full of scorn, Proudly wave above the corn. There is music at our feet In the clover, honey-sweet.

"You may track the winds that blow Through the cornfields as they go; From the wheat, as from a sea, Springs the lark in ecstacy. Now the bloom is on the blade, In the sun and in the shade. There is music at our feet In the clover, honey-sweet."

The Druids held the clover in great repute, deeming it, it is supposed, a charm against evil spirits. Hope was depicted by the ancients as a little child standing on tiptoe, and holding one of these flowers in his hand. 


\section{$D E A D$ LEAVES. \\ (Melancholy.)}

"Ah me! a leaf with sighs can wring My lips asunder."-E. B. BRowning.

ELLA INGRAM.

闰 $\mathrm{HE}$ withered leaves, trembling, love,

0. Fall to the ground; And strewn over all, love,

Lie dying around,

Killed by the frost, love,

The flowers scattered lie;

Their brightness is lost,

And neglected they die.

The world it looks dreary, love,

And thick falls the rain;

My heart it is weary, love, My head throbs with pain.

My hopes thickly fall, love, Like the leaves frorn a tree;

And I cannot recall

Their beauty to me. 
With thy heart I ain blest, love,

So I'll brave the chill rain;

And patiently rest, love,

Till the sun shines again.

And I hope when the Spring, love,

Gives leaves to the tree, Some flowers it will bring, love.

For vou and for me.

\section{WITHERING-WITHERING.}

HOFFMAN.

WITHERING-withering - all are withering-

All of Hope's flowers that youth hath nursed-

Flowers of love too early blossoming !

Buds of ambition too frail to burst.

Faintly-faintly-O ! how faintly

I feel life's pulses ebb and flow :

Yet sorrow, I know thou dealest daintily

With one who should not wish to live moe.

Nay! why, young heart, thus timidly shrinking

Why doth thy upward wing thus tire?

Why are thy pinions so droopingly sinking,

When they should only waft thee higher?

Upward-upward let them be waving,

Lifting the soul toward her place of birth :

There are guerdons there, more worth thy having-

Far more than any these lures of the earth. 


\section{MISTLETOE. \\ (I surmount Difficulties.) \\ "The sacred bush."-Tennyson.}

5E Mistletoe scarcely requires more than a passing 通, allusion : every one is acquainted with that remarkable custom which permits any lad to exact from any lass the toll of one kiss, when they accidentally meet where

"Sacred ceilings, dark and grey, Bear the mistletoe."

In Holstein the country people call the mistletoe "the spectre's wand," from the supposition that holding a branch of it will not only enable a man to see ghosts, but force them to speak to him.

\section{THE MISTLETOE.}

On Christmas-eve the bells were rung,

On Christmas-eve the mass was sung;

That only night in all the year

Saw the stoled priest the chalice near.

The damsel donned her kirtle sheen;

The hall was dressed with holly green : 
Forth to the woods did merry men go,

To gather in the mistletoe;

'Then opened wide the baron's hall

To vassal, tenant, serf, and all.

\section{UNDER THE MISTLETOE.}

UNDER the mistletoe, pearly and green, Meet the kind lips of the young and the old; Under the mistletoe hearts may be seen Glowing as though they had never been cold. Under the mistletoe, peace and goodwill Mingle the spirits that long have been twain; Leaves of the olive-branch twine with it still, While breathings of hope fill the loud carol strain Yet why should this holy and festival mirth In the reign of old Christmas-tide only be found? Hang up love's mistletoe over the earth, And let us kiss under it all the year round.

Hang up the mistletoe over the land

Where the poor dark man is spurned by the white:

Hang it wherever Oppression's strong hand

Wrings from the helpless humanity's right;

Hang it on high where the starving lip sobs, And the patrician one turneth in scorn; Let it be met where the purple steel robs Child of its father, and field of its corn. Hail it with joy in our yule-lighted mirth, But let it not fade with the festival sound; Hang up love's mistletoe over the earth, And let us kiss under it all the year round! 


\section{PASSION FLOWER.}

(Faith. When the flower is reversed it means Superstition.) HIS exquisite Hower is the symbol of Faith. It is supposed to represent the instruments of the Crucifixion; hence its name.

\section{THE PASSION-FLOWER.}

ALL-BEAUTEOUS flower! whose centre glows With studs of gold; thence streaming flows Ray-like effulgence; next is seen

A rich expanse of varying hue, Enfringed with an empurpled blue, And streaked with young Pomona's green.

High o'er the pointal, decked with gold, (Emblem mysterious to behold!)

A radiant cross its form expands; Its opening arms appear to embrace The whole collective human race,

Refuse of all men, in all lands. 


\section{TO THE PASSION-FLOWER.}

BARTON.

IF superstition's baneful art

First gave thy mystic name,

Reason, I trust, would stee] my heart

Against its groundless claim;

But if, in fancy's pensive hour,

By grateful feelings stirred,

Her fond imaginative power

That name at first conferred,-

Though lightly truth her flights may prize,

By wild vagary driven,

For once their blameless exercise

May surely be forgiven.

We roam the seas--give new-found isles

Some king's or conqueror's name:

We rear on earth triumphant piles

As meeds of earthly fame :-

We soar to heaven; and to outlive

Our life's contracted span,

Unto the glorious stars we give

The names of mortal man:

Then may not one poor floweret's bloom

The holier memory share

Of Him, who, to avert our doom,

Vouchsafed our sins to bear?

God dwelleth not in temples reared

By work of human hands,

Yet shrines august, by men revered,

Are found in Christian lands. 
And may not e'en a simple flower

Proclaim His glorious praise, Whose fiat, only, had the power

Its form from earth to raise?

Then freely let thy blossom ope Its beauties-to recall

A scene which bids the humble hope In Him who died for all!

\section{THE PASSION-FI,OWER.}

ANON.

ITs tender shoots, fostered with care, extend

Far in festooned luxuriance,

Its drooping flowers, to blend,

Sweet mixture! modesty and loveliness;

But more-when closely viewed, this flower appears

To bear the sacred mark of sacred tears,

Adding to the plant's beauty-holiness.

How like this flower can woman be, so fair!

So beautiful! too delicate her mind

Would seem, the world's rude withering frost to bear

Without some guardian's help, round whom to bind

Its tendrils in pure trusting confidence.

When rightly trained her blossoms bloom, they shine In more than beauty's lustre ; they combine

With earthly charms, celestial innocence,

Breathing of sacred things : yet, like that flower alone To those who view her near, her holiness is known. 


\section{HOLLY.}

(Foresight.)

"I, in this wisdom of the holly-tree, can emblems see."-Soutriey.

HIS tree is sacred to Christmas and domestic mirth.

\section{THE HOLLY TREE.}

SOUTHEY.

O READER ! hast thou ever stood to see

The holly tree?

The eye that contemplates it well perceives

Its glossy leaves,

Ordered by an Intelligence so wise

As might confound the atheist's sophistries.

Below a circling fence its leaves are seen,

Wrinkled and keen;

No grazing cattle through their prickly round

Can reach to wound;

But, as they grow where nothing is to fear, Smooth and unarmed the pointless leaves appear.

I love to view these things with curious eyes And moralize; 
And, in this wisdom of the Holly tree,

Can emblems see,

Wherewith perchance to make a pleasant rhyme, One which may profit in the after-time.

Thus, though abroad, perchance I might appear

Harsh and austere,

To those who on my leisure would intrude

Reserved and rude,

Gentle at home amid my friends I'd be, Like the high leaves upon the Holly tree.

And should my youth, as youth is apt, I know,

Some harshness show,

All vain asperities I day by day

Would wear away,

Till the smooth temper of my age should be Like the high leaves upon the Holly tree.

And as, when all the summer trees are seen So bright and green,

The Holly leaves a sober hue display,

Less bright than they;

But when the bare and wintry woods we see,

What then so cheerful as the Holly tree?

So, serious should my youth appear among

The thoughtless throng,

So would I seem among the young and gay

More grave than they,

That in my age as cheerful I might be As the green winter of the Holly tree. 


\section{THE HOLLY.}

ELIZA COOK.

THE holly! the holly! oh, twine it with the bayCome, give the holly a song;

For it helps to drive stern Winter away,

With his garments so sombre and long.

It peeps through the trees with its berries of red, And its leaves of burnished green, When the flowers and fruits have long been dead,

And not even the daisy is seen.

Then sing to the holly, the Christmas holly,

That hangs over peasant and king;

While we laugh and carouse 'neath its glittering boughs

To the Christmas holly we'll sing.

The gale may whistle, and frost may come

To fetter the gurgling rill ;

The woods may be bare and the warblers dumb-

But the holly is beautiful still.

In the revel and light of princely halls

The bright holly-branch is found;

And its shadow falls on the lowliest-falls

While the brimming horn goes round.

The ivy lives long, but its home must be

Where graves and ruins are spread;

There's beauty abont the cypress-tree,

But it flourishes near the dead;

The laurel the warrior's brow may wreathe,

But it tells of fears and blood.

I sing the holly-and who can breathe

Aught of that that is not good? 


\section{HAREBELL. \\ (Submission and Grief.)}

HIS lovely blossom merits its first meaning, but scarcely its last. 'Those who have listened to the faint, sweet rustle of its bells when the breeze passes over them, might rather think it a mirthful than a sad flower. And yet such has been generally the fancy it has given birth to in the poets. Witness the following charming verses:

\section{THE HAREBELL.}

R. HEQER.

WitH drooping bells of clearest blue, Thou didst attract my childish view,

Almost resembling

The azure butterflies that flew, Where on the heath thy blossoms grew

So lightly trembling.

Where feathery fern, and golden bloom, Increase the sand-rock cavern's bloom,

I've seen thee tangled,

'Mid tufts of purple heather bloom, By vain Arachne's treacherous loom, With dewdrops spangled. 
'Mid ruins tumbling to decay,

Thy flowers their heavenly hues display,

Still freshly springing

Where pride and pomp have passed away,

On mossy tomb and turret grey,

Like friendship clinging.

When glow-worm lamps illume the scene,

And silvery daisies dot the green

Thy flowers revealing,

Perchance to soothe the fairy-queen,

With faint sweet tones, on night serene,

Thy soft bells pealing.

But most I love thine azure braid, When softer flowers are all decayed, And thou appearest

Stealing beneath the hedgerow shade, Like joys that linger as they fade,

Whose last are dearest.

Thou art the flower of memory; The pensive soul recalls in thee The year's past pleasures ; And led by kindred thought will flee, Till back to careless infancy

The path she measures.

Beneath autumnal breezes bleak, So faintly fair, so sadly meek,

I've seen thee bending;

Pale as the pale blue veins that streak Consumption's thin transparent cheek, With death hues blending. 
Thou shalt be sorrow's love and mine.

The violet and the eglantine

With spring are banished;

In summer's beam the roses shine;

But I of thee my wreath will twine,

When these are vanished.

\section{THE H A R E E L L。}

CAROLINE SYMONDS.

IN Spring's green lap there blooms a flower Whose cup imbibes each vernal shower, That sips fresh Nature's balmy dew, Clad in her sweetest, purest blue; Yet shines the ruddy eye of morning, The shaggy wood's brown shade adorning. Simplest floweret! Child of May! Though hid from the broad eye of day, Doomed in the shade thy sweets to shed, Unnoticed droop thy languid head: Still Nature's darling thou'lt remain ; She feeds thee with her softest rain ; Fills each sweet bud with honied tears. With genial gales thy bosom cheers. Oh! then, unfold thy simple charms. In yon deep thicket's sheltering arms Far from the fierce and sultry glare, No heedless hand shall harm thee there; Still, then, avoid the gaudy scene, The flaunting sun, the embroidered green, And bloom and fade with chaste reserve, unseen. 


\section{THE HAREBELL.}

SCOTT.

"For me,"-she stooped, and, looking round, Plucked a blue harebell from the ground,"For me, whose memory scarce conveys An image of more splendid days, This little flower, that loves the lea, May well my simple emblem be; It drinks heaven's dew blithe as the rose? That in the king's own garden grows; And when I place it in my hair, Allan, a bard, is bound to swear He ne'er saw coronet so fair."

\section{THE HAREBELL.}

FAIRY bells of purest blue

Ring ye forth a message true ;

Tell how He who rakes the flower

Guards the tiniest by His power;

How the sun on lowliest shines,

How the dew thy wee cup lines;

Every bud, however small,

Kept by Him who guards us all,

This sweet message gladly tell

Fairy, airy, wee harebell. 


\section{$B R O O M$. \\ (Humility.)}

"The memorial flower of a princely race."

EOFFRY, Count of Anjou, acquired the surname of Plantagenet from the incident of his wearing a sprig of broom in his helmet on a day of battle. 'I'his Geoffry was second husband to Matilda, or Maud, Empress of Germany and daughter of Henry I. of Eng. land; and from this Plantagenet family were descended all our Edwards and Henrys.

It could not be expected that so romantic a story would escape the poets, and accordingly we find it embalmed in the following verses :

"Time was when thy golden chain of flowers Was linked, the warrior's brow to bind; When reared in the shelter of royal bowers, Thy wreath with a kingly coronal twined.

"The chieftain who bore thee high in his crest, And bequeathed to his race thy simple name,

Long ages past has sunk to his rest, And only survives in the rolls of fame.

"Though a fecble thing that Nature forms, A frail and perishing flower art thou;

Yet thy race has survived a thousand storms, That have made the monarch and warrior bow.

"The storied urn may be crumbled to dust, And time may the marble hust deface; But thou wilt be faithful and firm to thy trust, The memorial flower of a princely race." 


\section{VER VAIN. \\ (You enchant me.)}

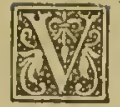

ERVAIN, or wild verbena, has been the floral symbol of enchantment from time immemorial. It was styled "sacred herb" by the Greeks, who ascribed a thousand marvellous properties to it, one of which was its power of reconciling enemies. Under the influence of this belief, they, as did also the Romans, sent it by their ambassadors on treaties of peace; and whenever they despatched their heralds to offer terms of reconciliation, renewal or suspension of hostilities, one $c^{f}$ them invariably bore a sprig of vervain. In his " 'Mruses' Elysium," Drayton calls it "holy vervain," and thus speaks of $1 \mathrm{t}$ :

"A wreath of vervain heralds wear Amongst our garlands named,

Being sent that weighty news to bear Of peace or war proclaimed."

The peoples of antiquity also frequently used this plant in various kinds of divinations, sacrifices, and incantations; and its specific name of verbena originally signified a herb used to decorate altars. Ben Jonson says,

"Bring your garlands, and with reverence place The vervain on the altar."

It was much valued by the Druids, being regarded by 
them as only second to the mistletoe : they used it largely in their divinations and casting of lots.

Sir William Davenant, in his poem of "Gondibert," alludes to its curative powers :

" Black melancholy rusts, that fed despair

Through wounds' long rage, with sprinkled vervain claared ; Strewed leaves of willow to refresh the air,

And with rich fumes his sullen senses cheered."

Vervain is used still amongst the Cornish peasantry as a charm against ague.

In gathering the vervain for "good luck," the herb is first crossed with the hand, and then blessed, thus :

"Hallowed be thou, Vervain,

As thou growest in the ground;

For in the Mount of Calvary

There thou first wast found."

\section{VERVAIN.}

IN the solemn midnight hour

When the spirit world hath power,

Here I pluck thee, vervain leaf

For my troubled heart's relief.

By the magic of thy spell

May my lover love me well;

May he ever faithful prove

To his early vows of love

And no worldly thoughts arise

To beguile his heart and eyes.

Vervain, holy, good and true,

This "good luck" I beg of you. 


\section{SWEET SEDGE.}

\section{(Resignation.)}

USH bearing is still kept up in the north-west of

England. Our ancestors strewed their rooms and churches with rushes, and of these, sweetest of all was the Sedge.

It is weil chosen for resignation, as when trodden on, its incense to God is sweetest.

\section{THE SWEET SEDGE.}

CALDER CAMPBELL.

$\mathrm{OH}$, river-side,

Where soft green rushes bear dark flowers,

And reedy grasses weave dark bowers,

Through which fleet minnows glide-

Oh, river-banks, let me from you convey

Something to scatter in yon ancient minster sray.

Oh, minster gray!

Where graves of friends beloved are found,

I come to thee with strewments.-Round

Each blade of grass, each spray

Of Acorus, a fragrant essence breathes,

Nature's own incense shed to sanctify these wreaths! 
$\mathrm{Oh}$, rushes green,

With blossoms wan or brown !-and ye

Sweet flags, from whose scent-rcots to me

Come thoughts of the Has Been, Ye are the fitting plants at eve to shed

A vague mysterious perfume o'er the silent dead !

"Not so!- -not so!"

A voice replies: "For joy alone

These reeds and rushes here are strewn!"

But I again cry : "Lo!

Joy's emblems here I fitly use, to prove

That life and death alike spring from God's holy love." 


\section{FLOWER DIALOGUES.}

I. love you

I love you, and it causes me both pleasure and pain . . . . . A Dog Rose.

I love you silently . . . . . . . A Red and White Rose.

I share your sentiments . . . . . Garden Daisy.

You may hope . . . . . . . . Meadow Daisy.

Speak out . . . . . . . . . Oxlip.

You may hope . . . . . . . . . Snowdrop.

I an sorry . . . . . . . . . . Purplc Hyacinth.

I share your sentiments . . . . . Double China Aster.

Do you love me? . . . . . . . . A Cockscomb.

If you love me, you will find out . . . Maiden-blush Rose.

I dare not love you . . . . . Veronica Speciosa, ana Rose.

I live for thee . . . . . . . Cedar leaf.

I do not love you . . . . . . Breaking off, and thront-

I die, if neglected . . . . . . Lamestinus.

ing away rose petals.

I offer you my friendship . . . . leaves.

Try to forget me . . . . . . Moonwort.

Remember me . . . . . . . Forget-me-not.

Be frank with me . . . . . . An Osier.

I give you the truest friendship . . A leaf of Oak-leaved

Geranizim.

Try to save me . . . . . . . Chicory, und Narcissus.

Be assured of my brotherly (or sisterly)

sympathy . . . . . . . Syringa.

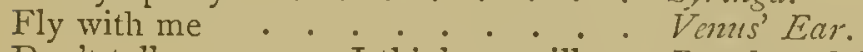

Don't talk nonsense-I think you silly . Purple Columbine or

Be my Valentine . . . . . . . Crocus,

Pomegranate. Alowers.

You are always delightful ... . Cineraria. 
I am very angry with you . . . . A sprig of Furze.

I have just remembered . . . . . China Aster.

Second thoughts are best . . . . China Aster.

I agree to it . . . . . . . A Straw.

I am foolishly anxious . . . . . Red Columbine.

Will you grant me an interview? . . Pimpernel.

How dare you! . . . . . . . A sprig of Larch.

Vou are a miser . . . . . . . Scarlet Auricula.

Be prudent . . . . . . . . Ziphion Spinosum.

Be warned in time-Beware! . . . Echites-also Purpurea.

Be mine . . . . . . . . . Four-leaved Clover.

You are betrayed . . . . . . White Catchfly.

Beware!... . . . . . Oleander.

Beware of a false friend . . . Francisca Latifolia.

I am in bonds . . . . . . . Convolvulus (aead) if in

You boast prison; living, if oflove.

You boast $\cdot \dot{0}^{\circ} \cdot \bullet^{-} \cdot$ Hydrangea. $^{-}$

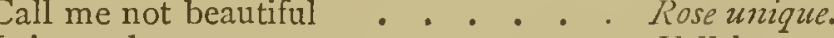

It is a calumny . . . . . . . Hellebore.

Beware of slander . . . . . . . Mleander and Hellebor.

Be merry . . . . . . . Y Yellow Crocuses.

Come down to me . . . . . . Facob's Ladder.

Be comforted . . . . . . . Scarlet Geranizm.

Could you bear poverty? . . . . Browallia famisoniz̈.

Do not fear . . . . . . . . Poplar leaves.

You are in danger . . . . . . . Rhododendron.

It is a dangerous pleasure . . . . Tuberose.

Your friend is deceitful . . . . . Ivy and Dogsbane.

Stop-Wait . . . . . . . Eupatorium.

Depart. . . . . . . . . Dandelion puff-ball.

I desire to please you . . . . . . Mezereon.

Despair not; God is everywhere . . White Fulienne.

It is difficult . . . . . . . . . . Blackthorn.

I am disappointed . . . . . . Carolina Syringa.

You have my disdain . . . . . Rue, or Yelione Carnation.

You are a good little housewife . - Flax, and Thrift.

Will you be a domestic wife? . . . Flax and Honeysuckle.

Do not despise my poverty . . . . Shepherd's Purse.

Do not refuse me . . . . . . Eschscholtzia.

I doubt you . . . . . . . . . Apricot blossom.

I envy you . . . . . . . : . The Bramble.

You are mistaken . . . . . . Bee Orchis or Fly Orchis

I can give you esteem; not love . . . Spider Wort and Strazwberry tree.

I expect you . . . . . . . . Anemone.

Forget me . . . . . . . Moonzwort,

I hope you may prosper . . . . . Flowering Almond, and Beech leaves. 


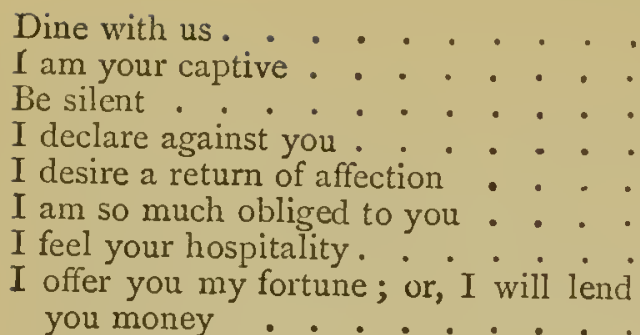

Give me a l. . . . . . Calceolaria.

Give me a kiss . . . . . . . . Mistletoe.

Do make haste . . . . . . . . Yellow Balsam.

Pray do; please do... . . . Burdock leaf.

I am independent . . . . . . Thistle.

I don't care for it . . . . . . . Candytuft.

I know I can't trust you . . . . . . Foxglove.

You are very feeble . . . . . . Dahlia.

I feel very jealous . . . . . . . French Marigold.

Are you jealous? . . . . . . . Yellow Rose.

Be happy . . . . . . . . . . Wood Sorrel.

Keep your promise . . . . . . Petuniu.

What shall I do? . . . . . . Aspen.

Let me go . . . . . . . . Butterfly weed.

Be merry . . . . . . . . Shamrock.

Live for me . . . . . . . . . Arbor Vita.

I love you

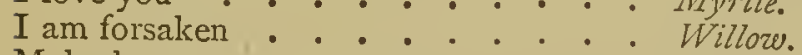

Make haste . . . . . . Dianthus.

My regrets will follow you to the grave Asphodel, Rosemary.

Remember me ... . . . . . Rosemary.

Marry me . . . . . . . . . . . American Linden.

I am very unhappy .. . . . . Dead leaves, dark Gera.

You are very clever . . . . . Clematis.

Your happiness wont last . . . . Viroinian Spidemeort.

Never despair . . . . . . . . Waicher by the Waysicie.

Be friends . . . . . . . . . . Sprig of Hizei.

Do make up our quarrel. . . . . A Filbert.

I forbid you . . . . . . . . Sprig of Privet.

I promise to protect you . . . . Bearded Crepis.

Pray for me . . . . . . . . White Verbcna.

Take care . . . . . . . . Golden Rod.

I prophecy that you will marry soon : Marigold, Woodbine, ant

Success crown your wishes Blackthorn.

For shame . . . . . . . . Piony.

We must part . . . . . . . Carolina fessamine.

Such worth is rare . . . . . Achimenes.

You surprise me . . . . . . . Trufle. 
I suspect you . . . . . . . . Champignon.

Accept my sympathy . . . . . . Balm.

Thanks . . . . . . . . Agrimony.

The variety of your conversation delights me . . . . . . . Clarkia.

Thee only do I love . . . . . Aroutus.

I will think about you . . : . . Pansy.

Tell the truth . . . . . . White Chrysanthemum.

I cannot accept your love . . . Scabious.

Unite against our enemies . . . Scarlet Verbena.

Don't be greedy . . . . . . Lupine.

Watch . . . . . . . . Dame Violet.

Will you accompany me to the East? . Stephanotis.

Will you dance with me? . . . . White Hy cinth.

You are cold . . . . . . . IJortensia.

You are my dearcst pet . . . . Mignonette.

I change but in death . . . . . Bay leaf.

Adieu, but remember me . . . . A broken flower and a Pansy.

\section{Let the bonds of marriage unite us.}

Blue Convolvulus . . . . Bonds.

Ivy . . . . . . . Marriage.

A few whole straws . . . . Unite us.

Farewell ! give me your good wishes. Forget me not. Sprig of Spruce Fir . . . . Farewell. Sweet Basil. . . . . . . Give me your good wishes. Forget-me-Not . . . . . . Forget me not.

Your patriotism, courage, and fidelity merit everlasting remembrance.

Nasturtium . . . . . Patriotism.

Oak Leaves . . . . Courage.

Heliotrope . . . . . Fidelity.

Everlasting, or Immortelles . . Everlasting Remembrance.

Your frivolity and malevolence will cause you to be forsaken by all.

London Pride . . . . . Frivolity.

Lobelia . . . . . Malevolence.

Laburnum . . . . Forsaken.

The flowers should be bound together with a fading leaf. 
Be assured of my sympathy. May you find consolation. Thrift. . . . . . . . . Be assured of my sympathy. Red Poppy. . . . . . Consolation.

By foresight you will surmount your difficulties. Holly . . . . . . Foresight. Mistletoe . . . . . Youwill surmountyour difficulties.

Your insincerity and avarice make me hate you. Cherry Blossom, or Foxglove . Insincerity. Scarlet Auricula . . . . Avarice. Turk's Cap . . . . . . Hatred.

Beware of deceit. Danger is near. Depart. Oleander . . . . . Beware. White Flytrap. . . . . Deceit. Rhododendron. . . . Danger is near. Dandclion, or Thistle Seed-head. Depart.

You are fickle, indiscreet, and affected. 'Therefore you are hated.

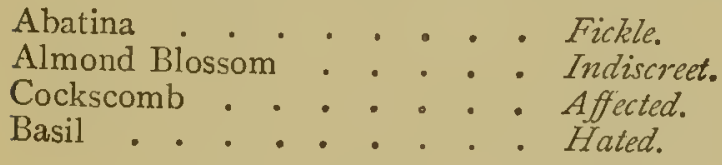

Humility, meekness, and truth have won the love I give to thee only.

Small Bindweed . . . . Hzmility.

Birch . . . . . . Meekness.

White Chrysanthemum : . Truth.

Parsley. . . . . : Have worn.

Arbutus : . : Love for thee only. 


\section{MODIFICATIONS}

oF

\section{THE FLOWER LANGUAGE.}

a flower be given reversed, its original signification is understood to be contradicted, and the opposite meaning to be implied.

A rosebud divested of its thorns, but retaining its leaves, conveys the sentiment, "I fear no longer; I hope:" thorns signifying fears, and leaves, hopes.

Stripped of leaves and thorns, the bud signifies, "There is nothing to hope or fear."

The expression of flowers is also varied by changing their positions. Place a marigold on the head, and it signifies "Mental anguish;" on the bosom, "Indifference."

When a flower is given, the pronoun $I$ is understood by bending it the right hand; thou, by inclining it to the left.

"Yes" is implied by touching the flower given with the lips.

"No," by pinching off a petal, and casting it away.

"I am" is expressed bv a laurel-leaf. twisted round the bouquet 
MODIFICA TIONS OF THE FLOWER LANGUAGE. 277

" $\$$ have," by an ivy-leaf folded together.

"I offer you," by a leaf of the Virginian Creeper.

$\mathrm{T} u$ win-a sprig of parsley in the bouquet.

"May," or "I desire"-an ivy tendril round the bociquet. 


\title{
DIAL OF FLOWERS.
}

\author{
ENGLISH NAMES. \\ LATIN NAMES. \\ Time of Time of \\ Opening. Closing. \\ Evening. \\ H. M. II. M.
}

Goat's Beard . . . . . Tragopogon luteum . $3 \quad 5 \quad \ldots \quad 9$ Iо Late-flowering Dandelion . Leontodon serotinum . 4 ○ Hawkweed Picris. . . . Picris echioides . - $4 \quad 5$... I2 0 Alpine-Hawk's Beard . . Crepis alpina . . - $4 \quad 5 \quad \ldots \quad 12 \quad 0$ Wild Succory . . . . . Cichorium intybus . $4 \begin{array}{lllll}4 & 5 & 8 & 9\end{array}$ Naked-stalked Poppy . . Papaver mudicaule . $50 \ldots 7$... 7 ० Copper-coloured Day Lily Hemerocallis fulva . $\begin{array}{lllllll}5 & \text { o } & 7 & 7 & 8\end{array}$ Smooth Sowthistle . . . Sonchus lavis . . . 5 O ... II I2 Blue-flower Sowthistle - . Sonchus alpinus - 5 o $\ldots$ I2 6 Field Bindweed . . . . Convolvulus arvensis $5 \begin{array}{lllll}5 & 6 & \ldots & 4 & 5\end{array}$ Spotted Cat's Ear . . . Hypocharis maculata $6 \begin{array}{lllll} & 7 & \ldots & 4 & 5\end{array}$ White Water Lily •. . Nymphaca alba . . 7 ० .. 50 Garden Lettuce . . . . Lactuca sativa . . . 7 ० ... 10

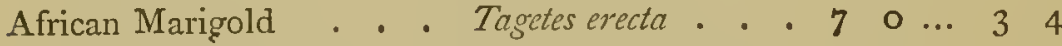
Mouse-ear Hawkweed . . Hieracium pilosella . 8 o... 2 o Proliferous Pink . . . . Dianthus proliferus . 8 o ... I 0 Field Marigold . . . . Calendula arvensis - $90 \ldots 30$ Purple Sandwort . . . Arenaria purpurea . 9 1о ... 23 Creeping Mallow. . . Malva Caroliniana . 9 I0 ... I2 I Chickweed . . . . . Stellaria media . . 9 10 .. Io 10 


\section{FLOWER GAME.}

Fen a large bouquet ready; let each person draw

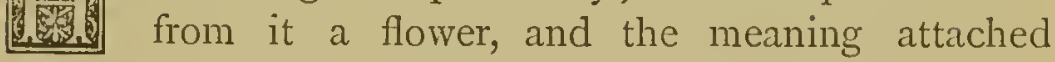
to it will typify the future consort's character. For example:-Say your bouquet for Spring consists of Violets, Hyacinths, Primroses, Daisies, Heartsease, Hawthorn, Daffodils, then the characters would be

Violet, modest; Hyacinth, playful ; Dark Hyacinth, mournful; Primrose, simple, candid; Daisy, an early riser; Heartsease, kind, charitable, or thoughtful ; Hawthorn, hopeful ; Daffodil, daring.

\section{For SUmmer.}

Rose, loving; White Rose, secret and canny; Pink, haughty; Jasmine, elegant or amiable ; Lily, pure; Mignonette, clever; Tulip, proud, conceited ; Stock, hasty : Mezereon, a flirt ; Foxglove, deceitful ; Myrtle, devoted; Laurel, brave ; a Reed, musical ; Hollyhock, ambitious; Marigold, rich ; Poppy, lazy ; Cornflower, extravagant; Dead leaves, old ; Geranium, stupid ; Mimosa, nervous; Thistle, patriotic; Thyme, merry; Aster, changeable; Oakleaf, hospitable.

The profession of the destined lover will be found thus:-Lily, a person of rank; Rose, an artist; Thistle, a Scotchman, and a soldier; Oakleaf, a farmer; Laurel, 
a poet; Foxglove, a lawyer ; Cypress, a doctor; Tulip, a freeholder; Passion-flower, a clergyman; Marigold, a merchant; Shamrock, an Irishman; Leek, a Welsh. inan.

Of course the persons who draw the flowers are supposed to be ignorant of their meaning; or they may draw blindfolded.

In winter this game may be played with painted flower cards ; painting a pack would be a pleasant home amusement; or dried flowers gummed on cards would answer perfectly well. The players then draw a card instead ô a flower. 


\section{THE VOCABULARY.}

\section{PART THE FIRST.}

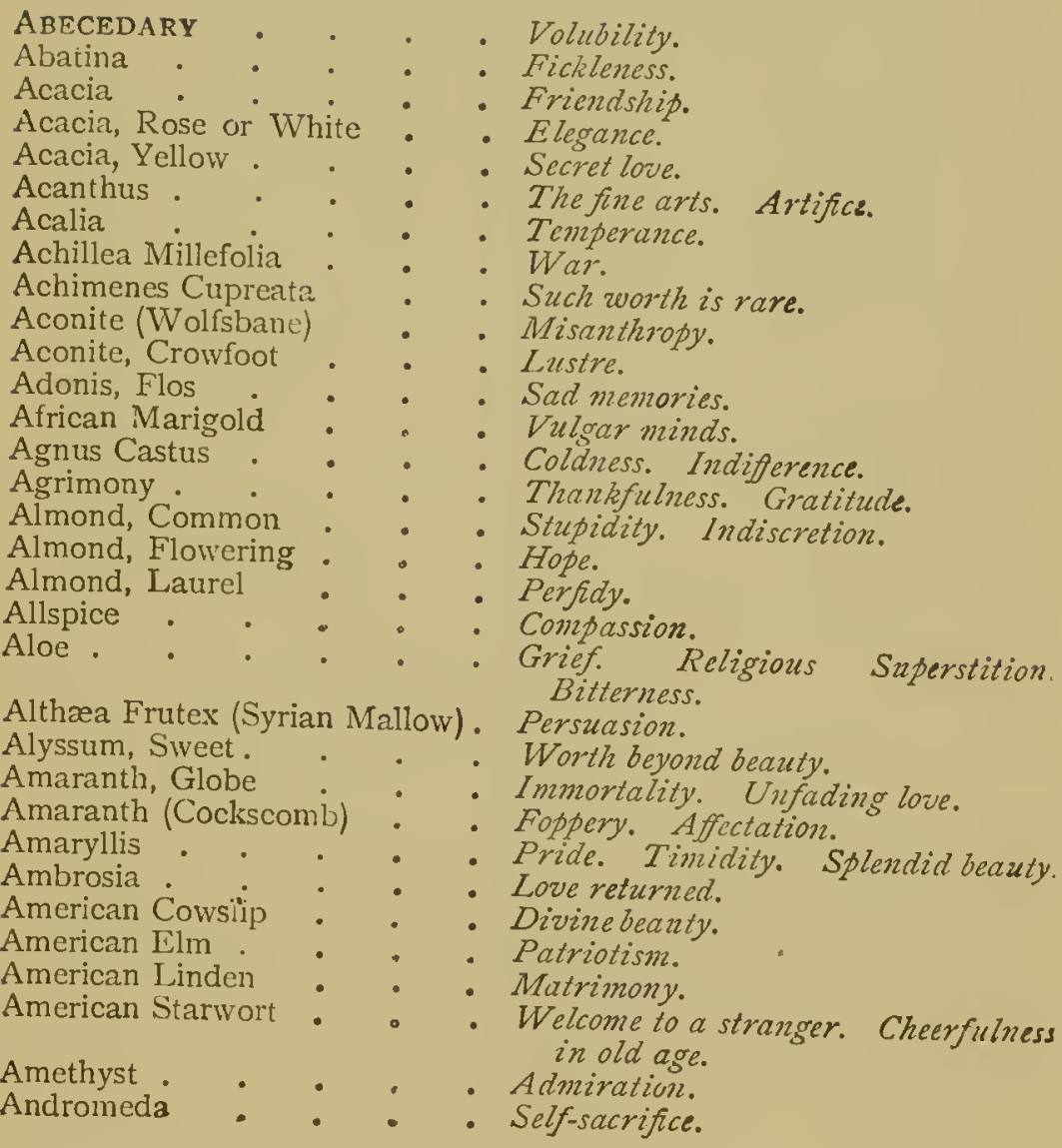


Anemone (Zephyr Flower) . Sickness. Expectation.

\section{Anemone, Garden . • Forsaken.}

Angelica . . : : . Inspiration, or Magic.

Angrec . . . . . Royalty.

Apocynum (Dogsbane) - Deceit.

Apple

Apple Blossom : :

- Temptation.

- Preference. Fame speaks him great and good.

Apple, Thorn . . . . Deceitful charms.

Apricot Blossom : • . Doubt.

Arbor Vitæ . - . Unchanging friendship. Live for

Arbutus . . Thee only do I love.

Arum (Wake Robin): : : Ardour. Zeal.

Ash-leaved Trumpet Flower . Separation.

Ash, Mountain . . . . Prudence, or With me you are safe.

Ash Tree . . . . . Grandeur.

Aspen Tree . . . . Lamentation, or Fear.

Aster (China) : : : : Variety. After-thonsht.

Asphodel . . . . Ny regrets follow you to the grave.

Auricula . . . . Painting.

Auricula, Scarlet • • . Avarice.

Auricula, Yellow : • . Splendour.

Autumnal Leaves . . . Mlclancholy.

Azalea

- Temperance.

BACHelors' Button . . Celibacy.

Balm. . . . . Sympathy.

Balm, Gentle : : : Pleasantry.

Balm of Gilead . : : : Cure. Relief.

Balsam, Red : . . . Touch me not.

Balsam, Yellow . . . . Impatience.

Barberry . . . . Sharpness of temper.

Basil .

Bay Leaf (Rose) Rhododendron

Bay Tree

Bay Wreath : :

Bearded Crepis : : :

Beech Tree , •

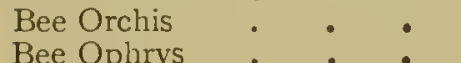

Begonia : :

- Deformity.

- Silence. Hush!

Bell Flower, Pyramidal • . Constancy.

Bell Flower (small white) . . Gratitude.

Belvedere . . . . I declare against you.

Betony . . . . . Surprise.

Bilberry : . . . Treachery.

Bindweed, Great : : Insinuation. Importunity.

Bindweed, Small . . . Humility.

Birch

- Meekness. 


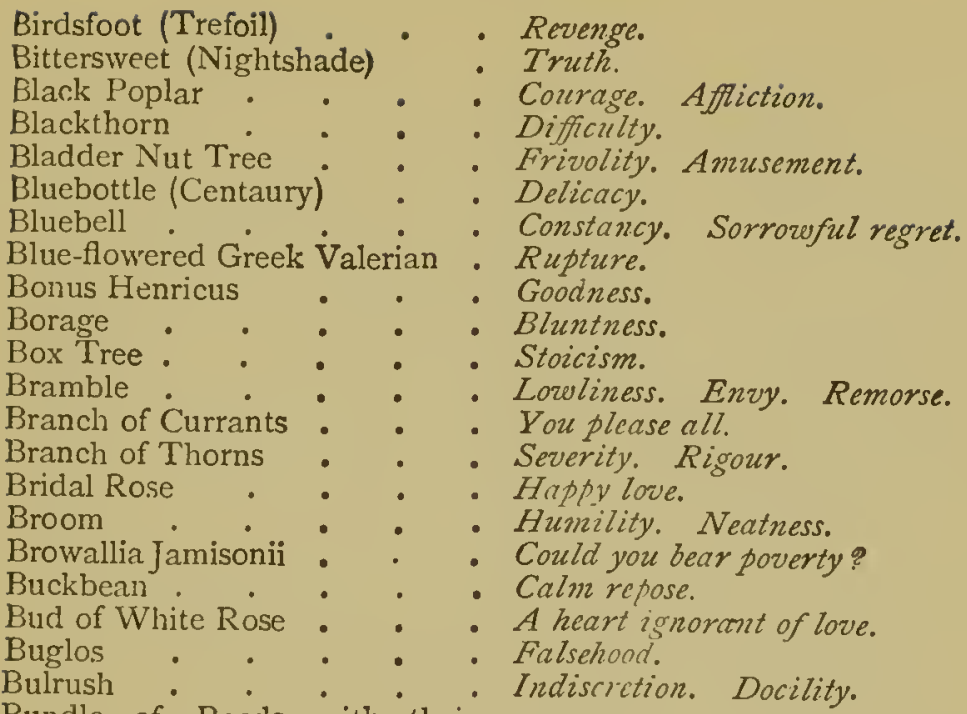

Bundle of Reeds, with their

Bur

Burdock

Buttercup (Kingcup)

Buttercups .

Butterfly Orchis

Butterfly Weed

CABBAGE .

Cacalia

Cactus

Calla Æthiopica

Calceolaria .

Calycanthus

Camellia Japonica, Red

Camellia, White

Campanula Pyramida

Camphire

Canary Grass

Candytuft .

Canterbury Bell .

Cape Jasmine

Cardamine

Carnation, Decp Red

Carnation, Striped

Carnation, Yellow

Cardinal Flower

Catchfly

Catchfly, Red
Music.

Rudeness. You weary me.

- Importunity. Touchme not.

- Ingratitude. Childishness.

- Riches.

- Gaiety.

- Let me go.

Profit.

Adulation.

Warmth.

- Magnificent beauty.

- I offer you pecuniury assistance, or 1 offer you my fortune.

- Benevolence.

- Unpretending excellence.

- Perfected loveliness.

- Aspiring.

- Fragrance.

- Perseverance.

- Indifference.

- Acknowledgment.

- I am too happy.

- Paternal error.

- Alas! for my poor heart.

Refusal.

- Disdain.

- Distinction.

- Dnar.

- Youthful love. 


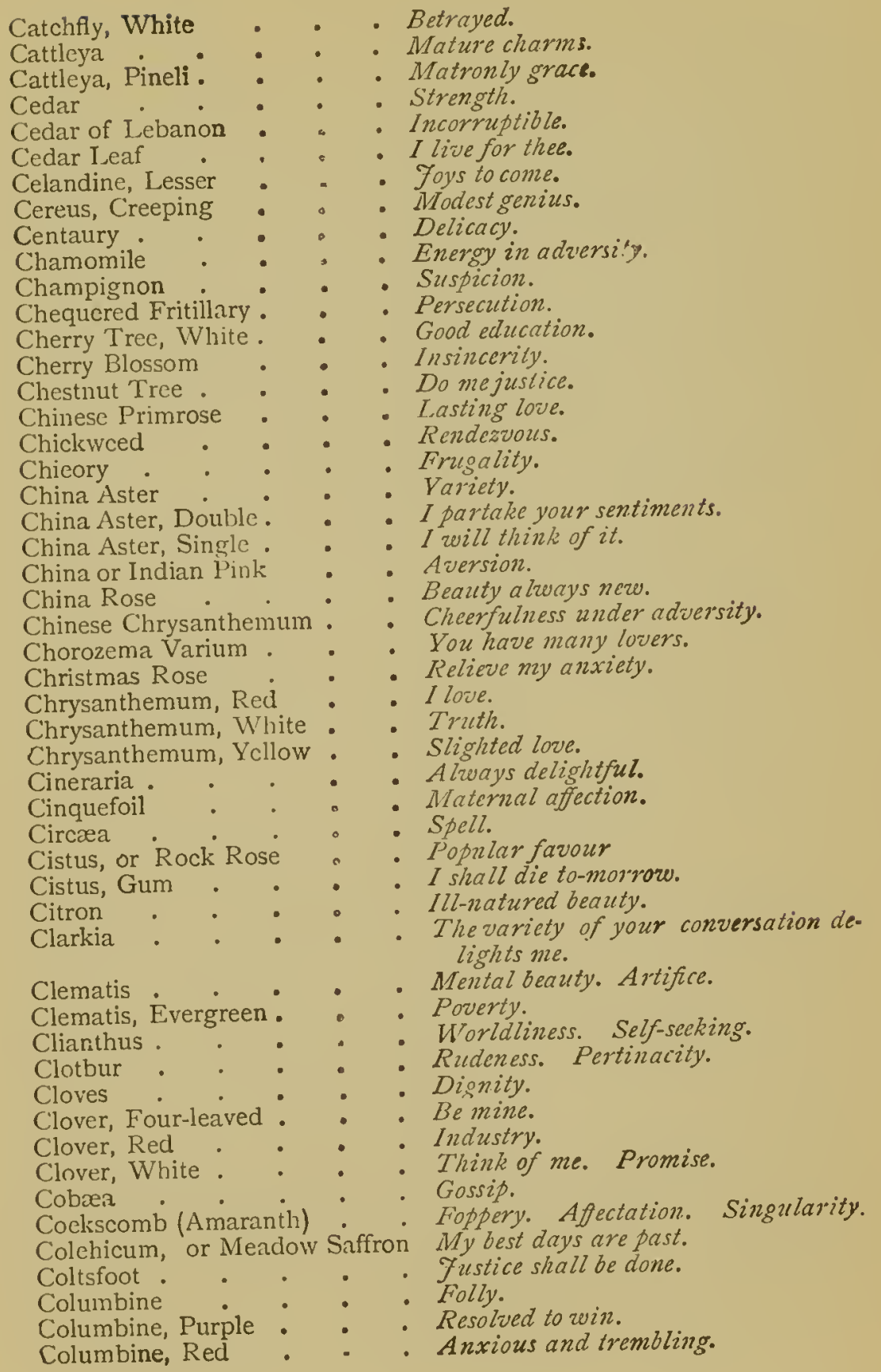


Convolvulus

Convolvulus Bl., Minor

Convolvulus, Major

Convolvulus, Pink

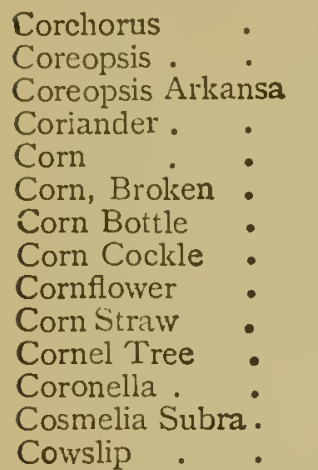

Cowslip (American)

Crab (Blossom) .

Cranberry

Creeping Cereus

Cress.

\section{Crocus}

Crocus, Spring

Crocus (Saffron)

Crown, Imperial

Crowsbill

Crowfoot

Crowfoot (Aconite-leaved).

Cuckoo Plant

Cudwecd, American

Currant

Cuscuta

Cyclamen

Cypress

DAFFODIL.

Dahlia

Daisy .

Daisy, Garden

Daisy, Michaelmas

Daisy, Parti-coloured

Daisy, Wild

Damask Rose .

Dandelion .

Dandelion, or 'Thistle-seed-head.

Diphne

Daphne Odora .

Darnel
Bonds.

- Repose. Night.

- Extinguished hopes.

- Worth sustained by judicious and tender affection.

Impatient of absence.

- Always cheerful.

- Love at first sight.

- Hidden worth.

- Riches.

- Quarrel.

- Delicacy.

- Gentility.

- Delicacy.

- Agreement.

- Duration.

- Success crown your wishes.

- The charm of a blush.

- Pensiveness. Winning grace. Youth. ful beauty.

Divine beauty. .

Ill nature.

Cure for heartache.

Horror.

Stability. Power.

Abuse not. Impatience.

Youthful gladizess.

Mirth. Chcerfulness.

Majesty. Power.

Envy.

- Ingratitude.

- Lisstre.

- Aridour.

- Unceasing remembrance.

- Thy frown will kill me.

- Meanness.

- Diffidence.

- Death. Mourning.

Regard. Unrequited love.

Instability. Pomp.

Innocence and Hope.

I share your sentiments.

Farewell, or Afterthought.

Beauty.

I will think of it.

Brilliant complexion.

Rustic oracle.

Depart.

Glory. Immortality.

Painting the lily.

Více. 
Dead Leaves . . . . Sadness.

Deadly Nightshade . • . Falsehood.

Dew Plant. . . . . A serenade.

Dianthus . . . . . Make haste.

Diosma * . . . Your simple elegance charms ne.

Dipteracanthus Spectabilis : Fortitude.

Diplademia Crassinoda . You are too bold.

Dittany of Crete $:$ : Birth.

Dittany of Crete, White : Passion.

Dock. $\quad$ : Patience.

Dodder of Thyme : $:$ Baseness.

Dogsbane . . . . Deceit. Falsehuvd.

Dogwood . . • • . Durability.

Dragon Plant . $\cdot$. . Snare.

Dragonwort • • • . Horror.

Dried Flax : $\bullet:$ : Utility.

EBony Tree . . . Blackness.

Echites Atropurpurea $\quad$ - Be warned in time.

Eglantine (Sweetbriar) : Potry. I wound to heal.

Elder . Zealousness.

Elm. . . Dignity.

Enchanter's Nightshade : Witchcraft. Sorcery.

Endive . . . Frugality.

Eschscholtzia : . . . Do not refuse me.

Eupatorium : . : Delay.

Evening Primrose . . . Silent Love.

Ever-bowing Candytuft . . Indifference.

Evergreen Clematis . . . Poverty.

Evergreen Thorn - . . Solace in adversity.

Everlasting . . . . Never-ceasing remembrance.

Everlasting Pea. : : Lasting pleasure.

FENNEL . . . . Worthy all praise. Strength.

Fern. - • . Fascination. Magic. Sincenty.

Ficoides (Ice Plant) : $: \quad$ Your looks freeze me.

Fig - . • • A Argument.

Fig Marigold : : : Idleness.

Fig Tree . • • . Prolific.

Filbert $\bullet \cdot \cdot$. Reconciliation.

Fir $: \quad: \quad: \quad$ : Time.

Fir Tree: : : $:$ Elevation.

Flax - : - : Domestic industry. Fute. J ferl your

Flax-leaved Golden-locks . . Tardiness.

Fleur-de-Lys : : Flame. I burn.

Fleur-de-Luce : : : Fire.

Flowering Fern : : : Reverie.

Flowering Reed : : Confidence in Heaven.

Flower-of-an-Hour : . Delicate beanty.

Fly Orchis . . : Error.

Flytrap : : : Deceit. 


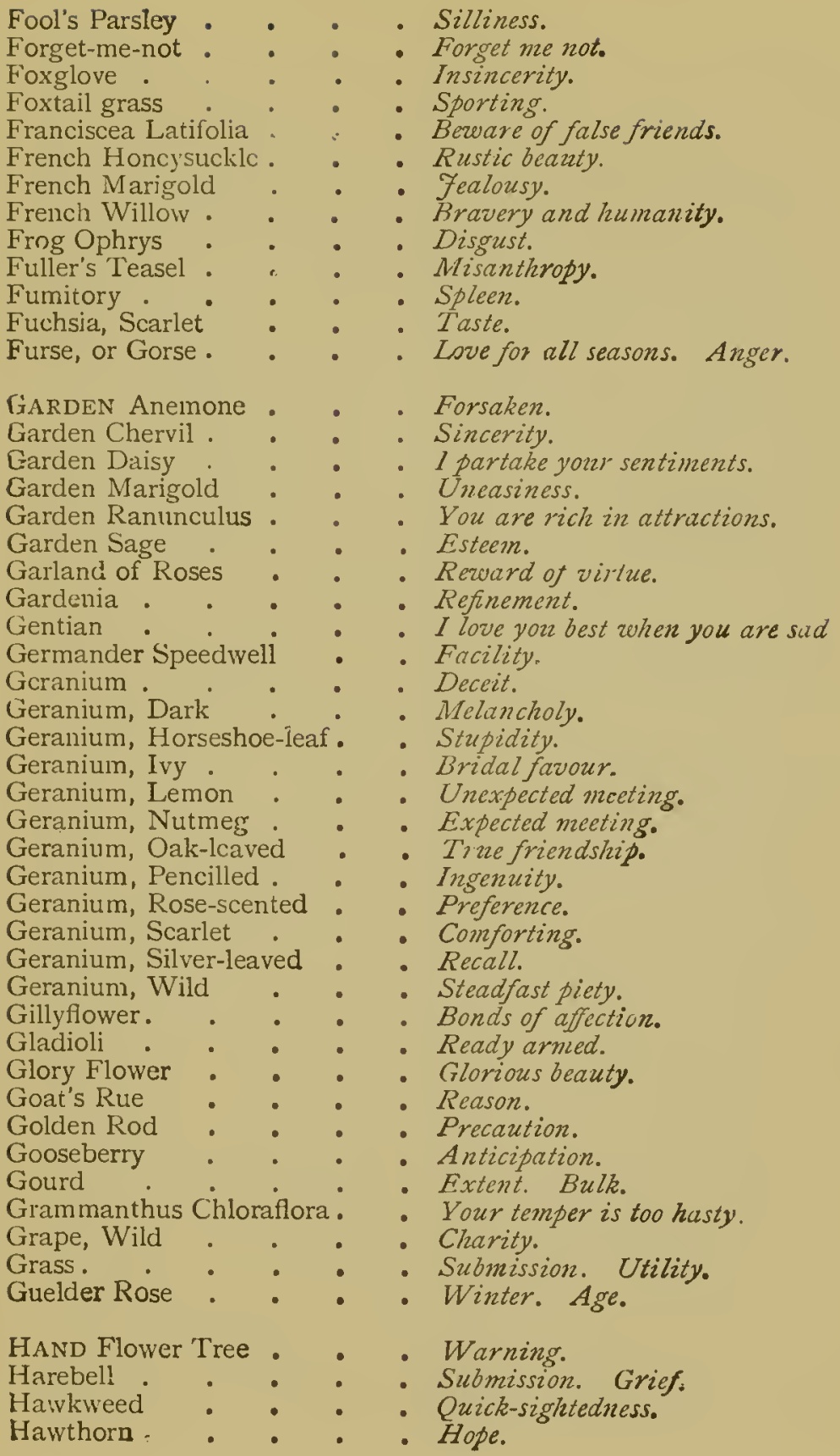


Hazel

Heartsease, or Pansy
Heath

Reconciliation.

Thoughts.

Solitude.

Helenium . . . . . Tears.

Heliotropc . . . . Devotion; or, I turn to thet.

Hellebore . - . Scandal. Calumny.

Helmet Flower (Monkshood) - Knight-errantry.

Hemlock . . . . You will be my death.

Hemp . $\cdot$. $_{\text {- Fate. }}$

Henbane . . . . $\quad$ - Imperfection.

Hepatica . . . . Confidence.

Hibiscus . . . . Delicate beauty.

Holly . . . . . Foresight.

Holly Herb : . $\quad$ - . Enchantment.

Hollyhock . - . Ambition. Fecundity.

Honesty . . . . Honesty. Fascination.

Honey Flower - . - . Love sweet and secret.

Honeysuckle . . . - Generous and dezoted affection.

Honeysuckle, Coral . . - The colour of my fate.

Honeysuckle, French : - Rustic beauty.

Hop . . . . . Injustice.

Hornbeam - . . - Omanent.

Horse Chestnut. . . . Luxury.

Hortensia. . . . . You are cold.

Houseleel. : $\quad$ - . Vivacity. Domestıc industry.

Houstonia. . . . . Content.

Hoya - . . . . Sculpture.

Hoyabella..$\quad$ - . - Contentment.

Humble Plant . . . . Despondency.

Hundred-leaved Rose . . Dignity of mind.

Hyacinth . - . Sport. Game. Play.

Hyacinth, Purple . - . Sorrozuful. I am sorry.

Hyacinth, White . . . Unorbtusive loveliness.

Hydrangea . . . . A boaster.

Hyssop . . . : . Cleanliness.

iCELANd Moss . . . Health.

Ice Plant . . . . - Your looks freeze me.

Imbricata . . . . . Uprightuess. Sentiments of honour.

Imperial Montague . . . Pozer.

Indian Cress . - . . Warlike trophy.

Indian Jasmine (Ipomoa) . - Attachment.

Indian Pink (Double) - . Always lovely.

Indian Plum . . . . Privation.

Iris . . . . . Mlessagc.

Iris, German - . : . Flame.

Ivy • . . - Friendship. Fidelity. Marrage.

Ivy, Sprig of, with 'Tendrils - Assiduous to please.

JACOB's Ladder . . . Come dozon.

Japan Rose - . . . Beauty is your only attraction.

Tapanese Lilies - $\quad$ - . $\quad$ - You cannot deccive me. 
Jasmine

Jasmine,

Jasmine, Carolina

Jasmine, Indian

Jasmine, Spanish

Jasmine, Yellow

Jonquil

Judas Tree

Julienne, White.

Juniper

Justicia

KENNEDIA

Kingcups .

LABURNUM

Lady's Slipper

Lagerstræmia, Indian

Lantana

Lapageria Rosea

Larch

Larkspur

Larkspur, Pink

Larkspur, Purple

Laurel

Laurel, Common, in flower

Laurel, Ground.

Laurel, Mountain

Laurel-leaved Magnolia

Laurestina

Lavender .

Leaves (dead)

Lemon

Lemon Blossoms

Leschenaultia Splendens

Lettuce

Lichen

Lilac, Field

Lilac, Purple

Lilac, White

Lily, Day .

Lily, Imperial

Lily, White

Lily, Ycllow

Lily of the Valley

Linden or Lime Trees

Amiability.

Transport of joy.

- Separation.

- I attach myself to you.

- Sensuality.

- Grace and clesance.

- I desire a return of affection.

- Unbelief. Betrayal.

- Despair not; God is everywhere.

- Succour. Protection.

- The perfection of female loveliness.

- Mental beauty.

- Desire of riches.

- Forsaken. Pensive beauty.

- Capricious beauty. Win me and zuear me.

Floguence.

- Rigour.

- There is no unalloyed grod.

- Audacity. Boldness.

- Lightness. Lovity.

- Fickleness.

- Haughtiness.

- Glory.

- Perfidy.

- Perseverance.

- Anibition.

- Dignity.

- A token.

- Distrust.

- Melancholy.

- Zest.

- Fidelity in love.

- You are charming.

- Cold-heartedness.

- Dejection. Solitude.

- Humility.

- First emotions of love.

- Foy of youth.

- Coquetry.

- Marjesty.

- Purity. Szuectness.

- Falsehood. Gaiety.

- Return of happiness. Unconscious sweetness.

Lint

Conjugal love.

Live Oak

Liverwort

Liquorice, Wild

I feel my obligations.

Liberty.

Confidence.

- I declare against you. 


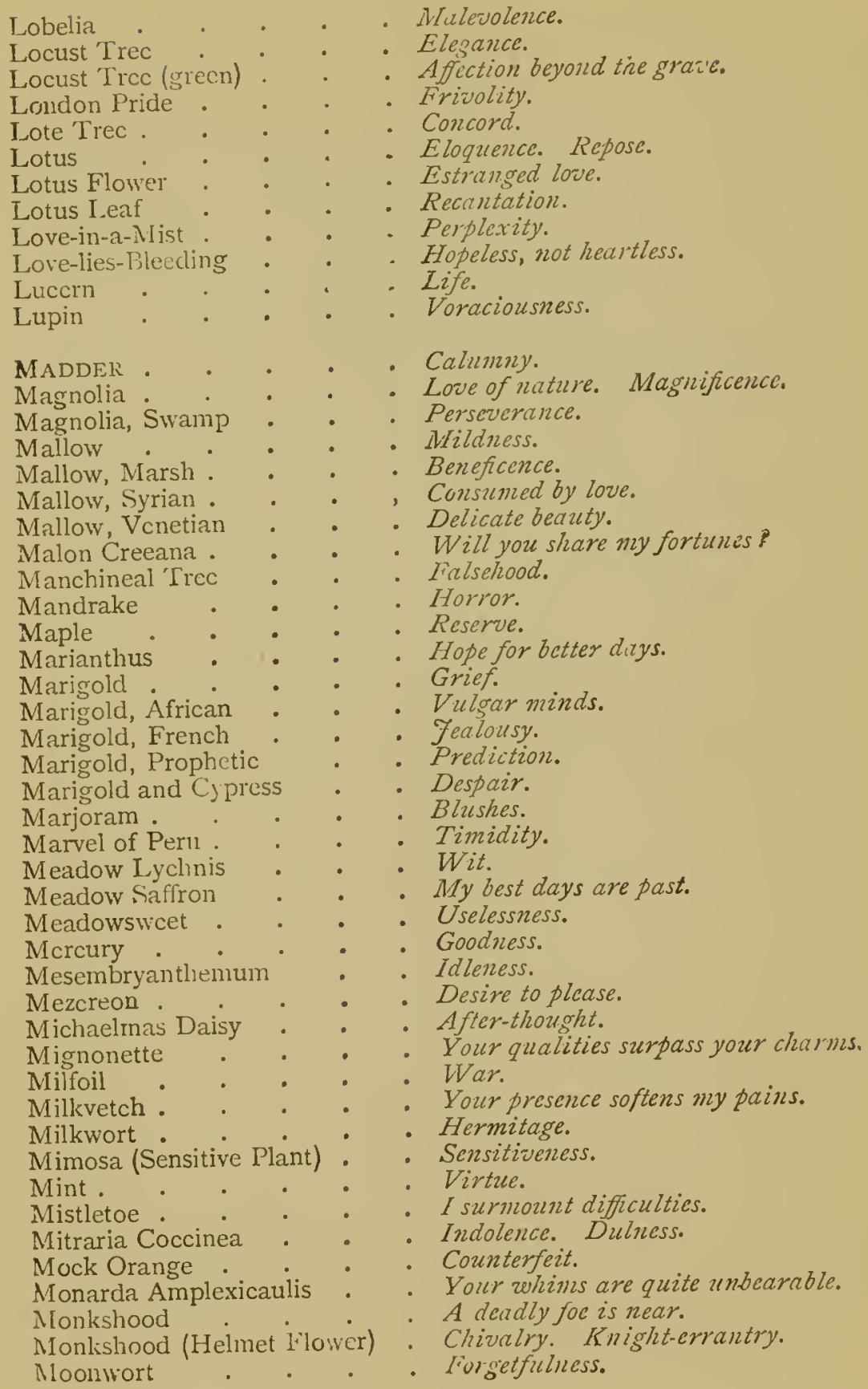




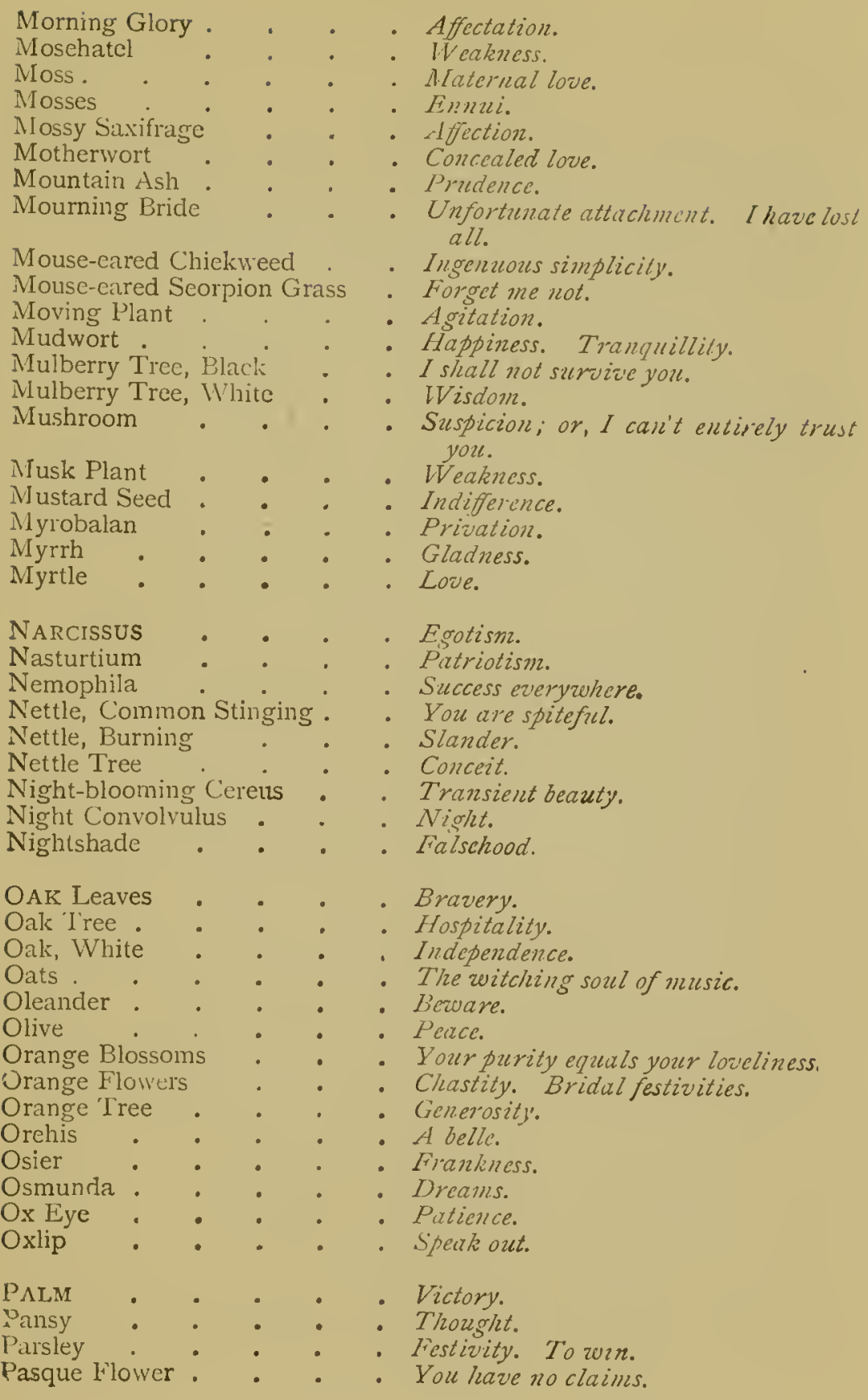


Passion Flowar .

Patience Doek .

Pea, Everlasting

Pea, Sweet

Peach

Peaeh Blosson.

Pear

Pear-tree . .

Pentstemon Azureum

Pennyroyal

Peony

Peppermint

Periwinkle, Blue

Periwinkle, Whitc

Persicaria.

Persimon

Peruvian Heliotrope

Petunia

Pheasant's Eye

Phlox

Pigeon Berry

Pimpernel

Pine.

Pine-apple

Pine, Pitch

Pine, Spruec

Pink

Pink, Carmation

Pink, Indian Doublc

Pink, Indian Single

Pink, Mountain

Pink, Red Double

Pink, Single

Pink, Variegated

Pink, White

Plantain

Plane Tree

Plum, Indian

Plum Tree

Plum, Wild

Plumbago Larpenta .

Polyanthus

Polyanthus, Crimson

Polyanthus, Lilac

Pomcgranate

Pomegranate Flower .

Poor Robin

Poplar, Black .
Religious superstition, when the flower is reversed, or Faith if erect.

\section{Patience.}

- An appointed meeting. Lasting pleasure.

Departure.

- Your qualities, like your charms, are unequalled.

I am your captive.

- Affection.

- Comfort.

- Hish-bred.

- Hilee arvay.

- Shame. Bashfulness.

- Warmth of fecling.

- Early friendship.

- Pleasures of memory.

- Restoration.

- Bury me amid Nature's beauties.

- Devotion.

- Your presence soothes me.

- Remembrance.

- Unanimity.

Indifference.

- Change. Assignation.

- Pity.

- You are perfect.

- Philosophy.

Hope in adversity.

Boldness.

Woman's love.

- Always lovely.

- Aversion.

- Aspiring.

- Pure and ardent lor'e.

- Pure love.

- Refusal.

- Ingenionsness. Talent.

- White man's footsteps.

- Genius.

Privation.

Fidelity.

Independence.

Holy wishes.

Pride of riches.

The heart's mys'ery.

Confidence.

Foolishness.

Mlature elegance.

Compensation, or an Equivaluut.

Courage.

Time. 
Poppy, Red

Poppy, Scarlet .

Poppy, White

Potato

Poteritilla .

Prickly Pear

Pride of China

Primrose

Primrose, Evening

Primrose, Red .

Privet

Purple Clover :

Pyrus Japonica .

QUAKING-GRASS

Quamoclit

Queen's Rocket.

Quince

RAGGED-ROBIN

Ranunculus

Ranunculus, Garden

Ranunculus, Wild

Raspberry .

Ray Grass

Red Catchfly

Reed

Reed, Split

Rhododendron (Rosebay)

Rhubarb

Rocket

Rosa Mundi

Rose, Austrian

Rose, Bridal

Rose, Burgundy

Rose, Cabbage

Rose Campion

Rose, Caroline.

Rose, China

Rose, Christmas

Rose, Daily

Rose, Damask

Rose, Deep Red

Rose, Dog

Rose, Guelder

Rose, Hundred-leaved

Rose, Japan

Rose, Miiden-blush

Rose, Montiflora

Rose, Musk

Rose, Musk, Cluster:
- Consolation.

- Fantastic extravagance.

- Sleep. My bane.

- Benevolence.

- I claim, at least, your esteem.

- Satire.

- Dissension.

- Early youth and sadness.

- Inconstancy.

- Unpatronized merit.

- Prohibition.

- Provident.

- Fairies'fire.

Agitation.

Busybody. You are the queen of coquettes.
Firshion.

Temptation.

Wit.

You are radiant with charms.

- You are rich in attractions.

- Ingratitude.

- Remorse.

- Vice.

- Youthful love.

- Complaisance. Music.

- Indiscretion.

- Danger. Bcware.

- Advice.

Rivalry.

Variety.

Thou art all that is lovely.

Happy love.

Unconscious beauty.

Ambassador of love.

Only deserve my love.

Love is dangerous.

- Beauty always new.

- Tranquillize my anxiety.

- Thy smile I aspire to.

- Brilliant complexion.

- Bashful shamo.

- Love, pleasure, and pain.

- Winter. Agc.

- Pride.

- Beauty is your only attraction.

- If you love me you will find it cut.

- Grace.

- Capricious beauty.

- Charming. 
Rose, Red : $:$
Rose, Single
Rosc, Thornless
Rose Unique :
Rose, White $:$
Rose, White (withered)
Rose, Yellow
Rose, York and Lancastcr
Rose, Full-blown, placcd over
two Buds

Rose, White and Red together .

Roses, Crown of

Rosebud, Red

Rosebud, White

Rosebud, Moss

Rose Leaf

Rosemary

Rudbeckia

Rue

Rush : : : : : : Docility.

Rye Grass . . . . . Changeable disposition.

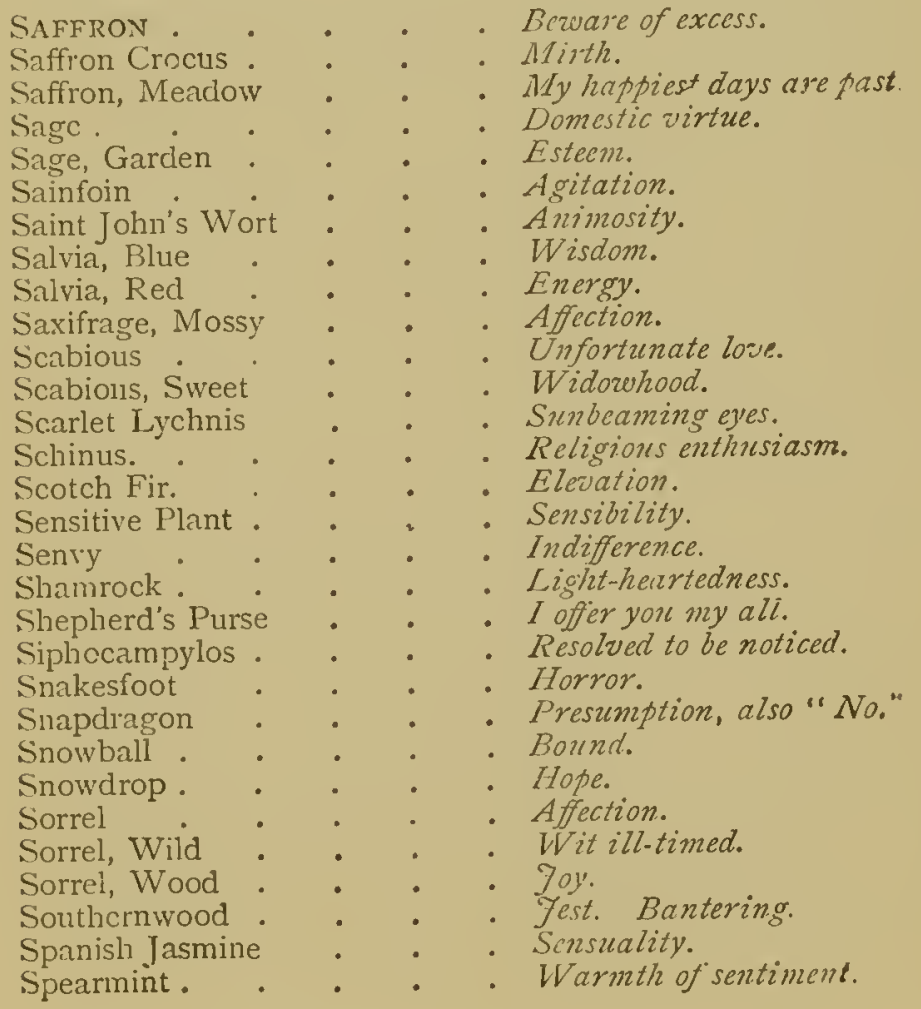

\section{Secrecy.}

Unity.

Revard of virtue.

Pure and loveiy.

Girlhood.

Confession of love.

- You may hope.

- Remembrance.

- Fustice.

Disdain.

Docility.

Bezuare of excess.

Mirth.

My happiest days are past

Domestic virtue.

Estecm.

Agitation.

Saint John's Wort • $\cdot$ Wisdom.

Salvia, Red • . Energy.

Saxifrage, Mossy •. . Affection.

Scabious S

Scarlet Lychnis

Schinus.

Scotch Fir

Senry

Shamrock

Shepherd's Purse

Siphecampylos

Snakesfoot

Snapdragon

Snowball

Snowdrop

Sorrel

Sorrel, Wild

Sorrel, Wood

Spanish Jasmine

Spearmint 
Speedwell .

Speedwell, Germander

Speedwell, Spiked

Spider Ophrys .

Spiderwort

Spindle Tree

Star of Betllehem

Starwort

Starwort, Ameriean

Stephanotis

St. John's Wort

Stoek

Stoek, Ten-week

Stoneerop .

Straw (broken)

Straw (whole)

Strawberry Blossoms.

Sultan, Lilae

Sultan, White

Sultan Yellow

Sumaeh, Veniee

Sunflower, Dwarf

Sunflower, Tall

Swallow-wort

Sweet Basil

Sweetbriar, Ameriean

Sweetbriar, European

Sweetbriar, Yellow

Sweet Pea.

Sweet Sultan

Sweet Sedge

Sweet William .

Syeamore .

Syringa

Syringa, Carolina
Spiked Willow Herb.

Strawberry Tree.

Female fidclity.

Facility.

- Semblance.

- Adroitness.

- Estecm, zot love.

- Pretension.

- Yourcharmsare engraven on my heart.

- Purity.

- After-thouertht.

- Cheerfulncss in old age.

- Will you accompany me to the East?

- Superstition.

- Lasting beauty.

- Promptness.

- Tranquillity.

- Rupture of a contract.

- Union.

- Foresight.

- Esteem, not love.

- I forgiz'e you.

Srueetness.

- Contempt.

Splendour.

Adoration.

Haughtiness. False riches.

- Cure for heartache.

- Good zuishes.

Simplicity.

I wound to heal.

- Decrease of love.

Delicate pleasures.

Felicity.

Resignation.

Gallantry. Dexterity.

- Curiosity. Menory. Fraternal sympathy.

Disappointment.

TAMARISK

Tansy, Wild

Teasel

Tendrils of Climbing Plants

Thistle, Common

Thistle, Fuller's .

Thistle, Seoteh .

Thorn Apple

Thorn, Braneh of

Thrift

Throatwort

Thyme

Tiger Flower

Traveller's Joy .
- Crime.

- I declare zuar against you

- Misanthropy.

- Ties.

- Austerity. Independencc.

- Misanthropy.

- Retaliation.

- Deceitful charnis.

Severity.

- Sympatizy.

- Neglected beauty.

- Activity or Courage.

- For once may pride befriend mis Safetv 
Tree of Life - . + . Old age.

Trcfoil . . . Kevenge.

Tremella Nestoc : : Resistance.

Trillium l'ictum . . . Modest beauty.

Triptilion Spinosum . . . Be prudent.

Truffe . . . . Surprise.

Trumpet Flower : : Fame.

Tuberose . . . - Dangerous pleasures.

Tulip, Red . . . . Declaration of love.

Tulip, Variegated : . . Beautiful eyes.

Tulip, Yellow . $\quad$. $\quad$ Hopeless love.

Tulip . . . Charity.

Tussilage, Sweet-scented : $\quad$ Fustice shall be done you.

VAleRIAN . . . An accommodating disposition.

Valerian, Greek. : : : Rupture.

Venice Sumach . . . . Intellectual excellence. Splendour.

Venus's Car . . . . Fly zoith me.

Venus's I ooking-glass : . Flattery.

Venus's Trap . . . . Deceit.

Verbena, Pink . . : . Fumily unzon.

Verbena, Scarlet . . . Unite against evii; or, Church unity.

Verbena, White. . . . Pray for me.

Vernal Grass . . . . Poor, but happy.

Veronica . . . . Fidelity.

Veronica Speciosa . - . Keep this for my sake.

Vervain . . . . Enchantment.

Vine . . . . . Intoxication.

Violet, Biue • • . . Faithfulness.

Violet, Dame . . . . Watchfulness.

Violet, Sweet - . . . Modesty.

Violct, Yellow . . . . Kural happiness.

Virginia Crecper . . . I cling to you both in sunshine and

Virgin's Bower . . . . Filial love.

Viscaria Oculata - . . Will you dance with me?

Volkamenia . . . . May you be happy.

WALLFLOWER • . . . Fidelity in adversity.

IValnut . . . Intellect. Stratagem.

Watcher by the Wayside: $\quad$ Never despair.

Water-Lily . . . . Purity of heart.

Water-Melon . . . . Bulkiness.

Wax Plant . . . . Susceptibility.

Wheat Stalk . . . . Riches.

Whin . . . . . Anger.

White Flytrap : $\quad: \quad$ : Deceit.

White Jasmine . . . Amiableness.

White Lily - . . . Purity and modesty.

White Mullein : • : Good-nature.

White Oak : $:$. Independence.

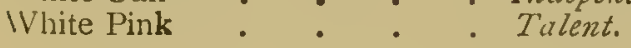




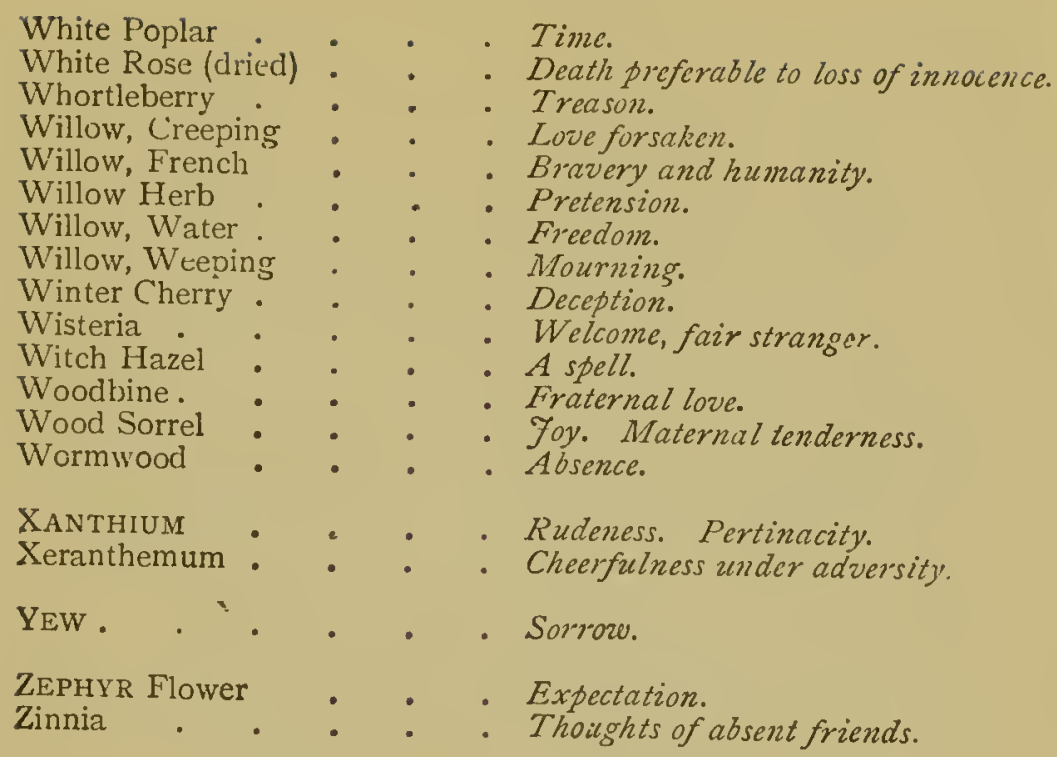

\section{PART THE SECOND.}

\begin{tabular}{|c|c|c|c|c|}
\hline ABSENCE . & - & - & & Wormwood. \\
\hline Abuse not & - & - & $\bullet$ & Crocus. \\
\hline Acknowledgme & & - & $\bullet$ & Canterbury Bell. \\
\hline Activity or Cou & irage & - & - & Thyme. \\
\hline A deadly foe is & near & - & - & Moonkshood. \\
\hline Admiration & $\cdot$ & - & - & Amethyst. \\
\hline Adoration . & - & - & - & - Dwarf Sunflower. \\
\hline Adroitness & - & - & • & - Spider Ophrys. \\
\hline $\begin{array}{l}\text { Adulation. } \\
\text { Advice }\end{array}$ & - & - & $\bullet$ & - Cacalia. \\
\hline $\begin{array}{l}\text { Advice } \\
\text { Affection : }\end{array}$ & • & - & - & - Rhubarb. \\
\hline Affection . & • & - & • & - Mossy Saxifrage. \\
\hline Affection . & : & $\bullet$ & & - Pear. \\
\hline Affection beyon & d the & grat: & e & - Sorrel. \\
\hline Affection, Mate & ernal, & & & - Green Locust. \\
\hline Affectation & - & - & • & - Cinquefoil. \\
\hline Affectation & - & - & - & $\begin{array}{l}\text { Cockscomb Amaranth. } \\
\text { Mornino Glory. }\end{array}$ \\
\hline Affliction & - & & & $\begin{array}{l}\text { - Morning Glory. } \\
\text { - Black Poplar. }\end{array}$ \\
\hline After-thought & - & - & & $\begin{array}{l}\text { - Mlack Poplar. } \\
\text { - Michaeimas Daisy. }\end{array}$ \\
\hline After-thought & - & - & & $\begin{array}{l}\text { - Michaeimas Daisy. } \\
\text { - Starwort. }\end{array}$ \\
\hline After-thought & - & - & & $\begin{array}{l}\text { - Starwort. } \\
\text { - China Aster. }\end{array}$ \\
\hline Agreement & - & - & $\bullet$ & $\begin{array}{l}\text { - China Aster. } \\
\text { - Straw. }\end{array}$ \\
\hline Age. & - & - & $\bullet$ & - Straw. \\
\hline
\end{tabular}


A gritation .

Agitation .

Alas! for my poor heart

Always chccrful.

Always delightiful

Always lovely

Ambassador of Love

Amiability

Anger

Anger

Animosity.

Anticipation

Anxious and trembling

Ardour, Zeal

Augument

Arts .

Artifice

Assiduous to please.

Assignation

Attachment

Audacity .

Avarice

Aversion .

BANTERING

Easeness .

Bashfulness

Bashful shame

Be prudent

Be warned in time

Beautiful eyes

Reauty

Beanty always new

Beauty, Capricious

Beauty, Capricious

Beauty, Delicatc

Beauty, Delicate

Bcauty, Divine .

Bcauty, Glorious

Bcauty, Lasting

Beauty, Magnificent

Beauty, Mental

Beauty, Modest

Beauty, Neglected

Beauty, Pensive

Beauty, Rustic .

Beauty, Unconscious

Bcauty is your only attraction

Belle

Be mine.

Beneficence

Benevolence 


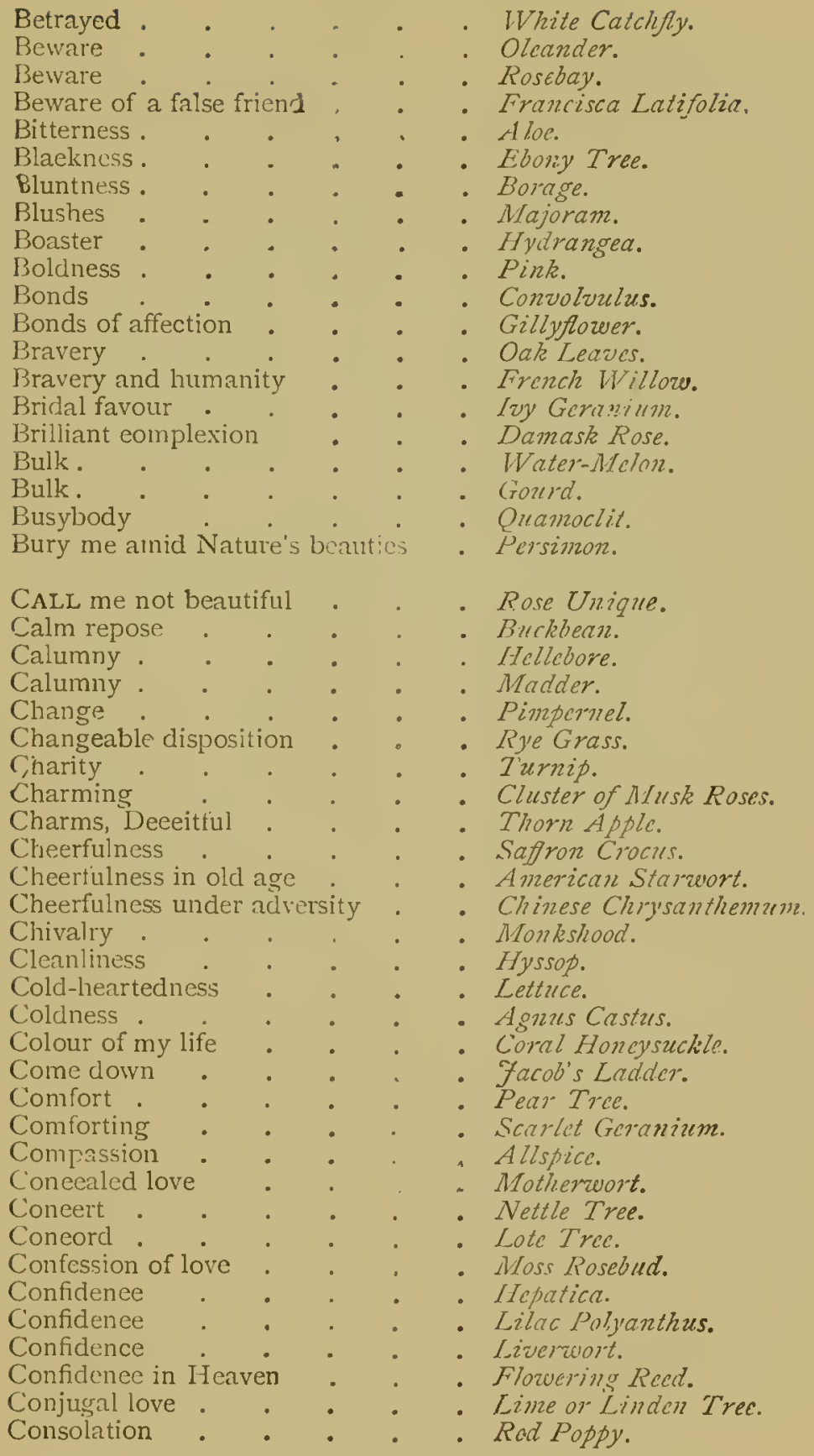




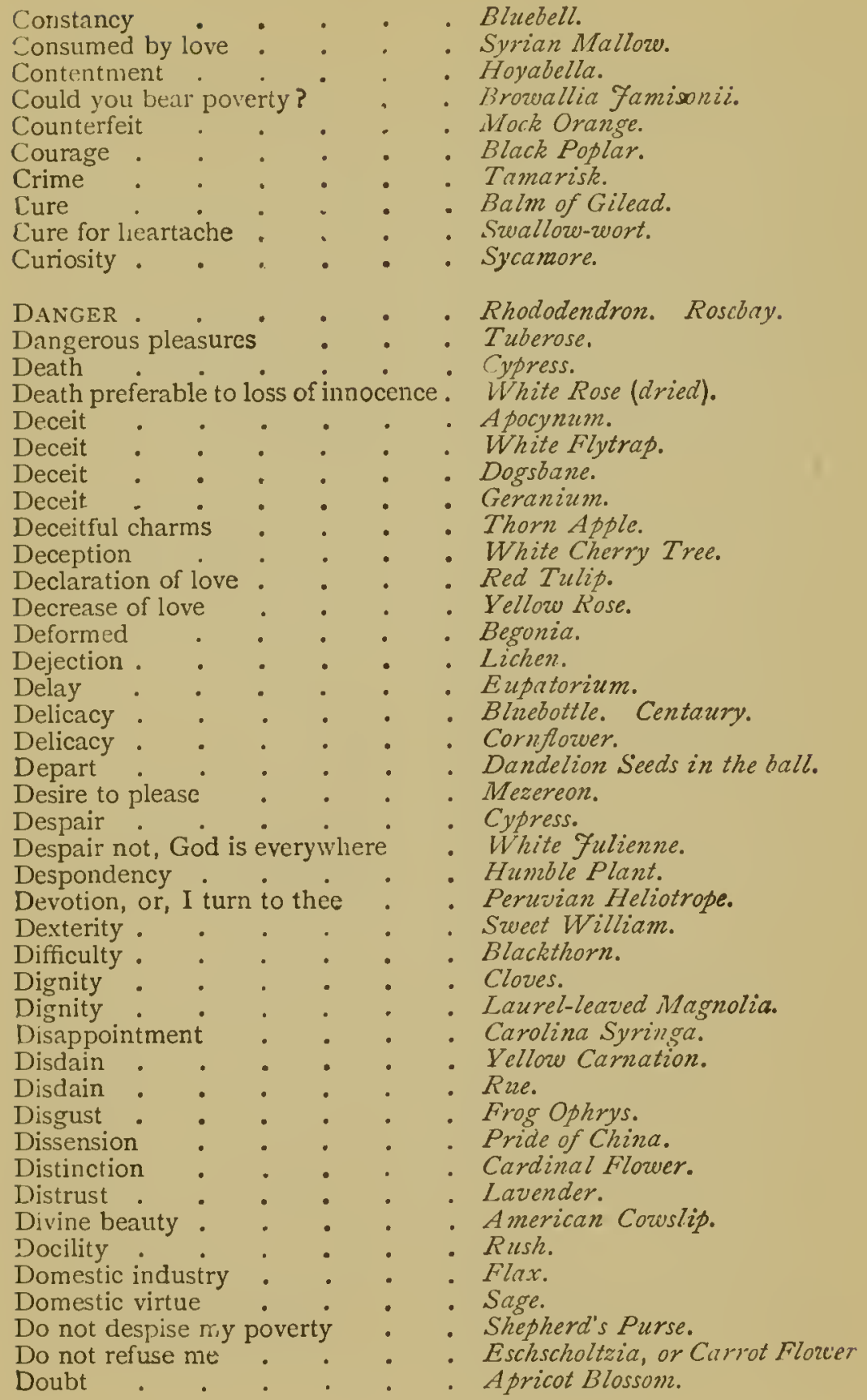




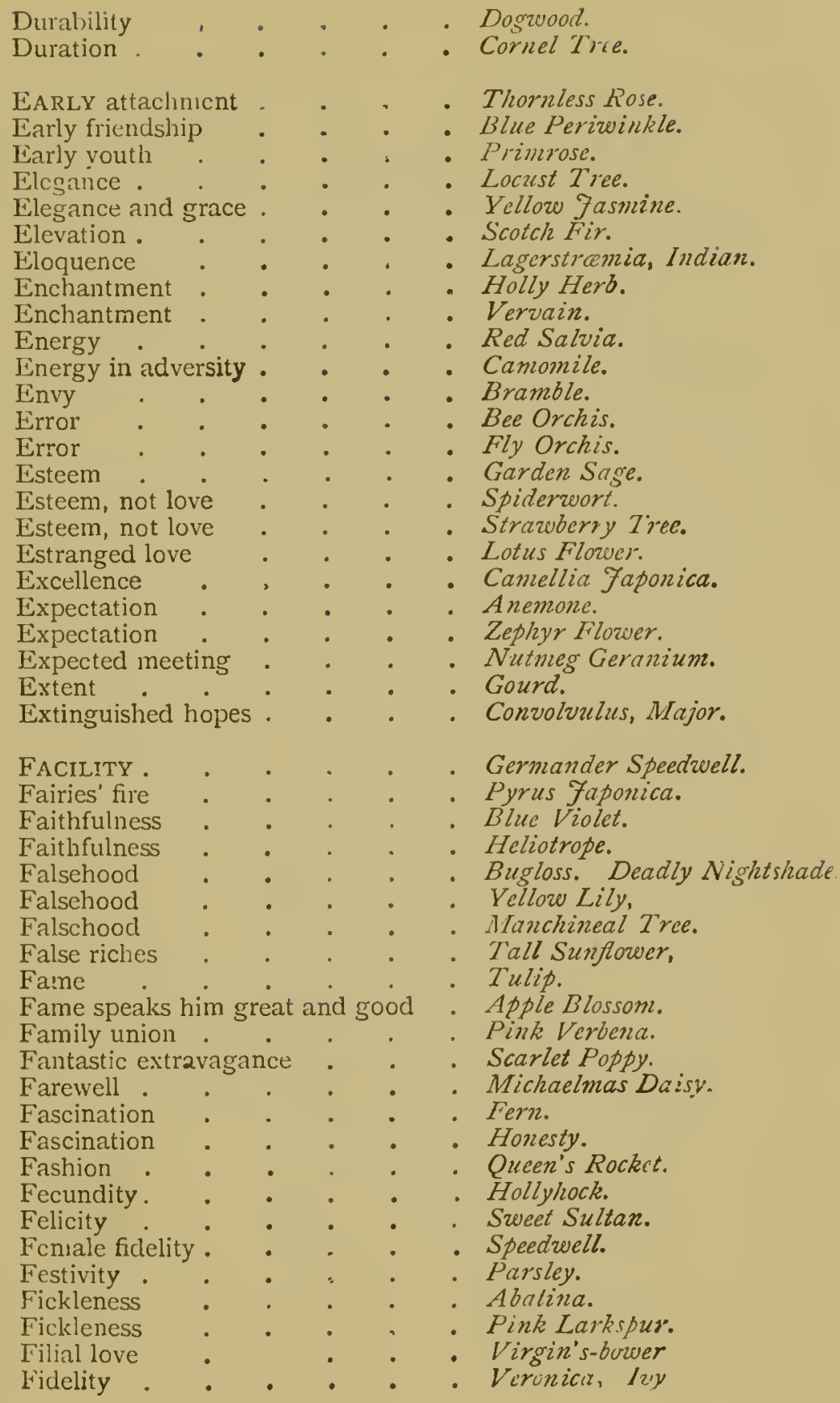


Fidelity . . . . Plum Tree.

Fidelity in adversity . $:$. Wallfower.

Fidelity in love. . . . Lemon Blossoms.

Fire . . . . Fleur-de-Luce.

First emotions of love : : : Purple Lilac.

Flame . . Fleur-de-lis. Iris.

Flattery : $: \quad \cdot \quad \cdot \quad \cdot$. Thus's Locking-glass.

Flec away $\cdot . \quad . \quad$. Pennyroyal.

Fly with me . . . : . Venus's Car.

Folly $. \quad . \quad$. Columbine.

Foppery . : . . . Cockscomb. Amaranth.

Foolishness . . . . Pomegranate.

Foresight . . . . . Holly.

Forgetfulness . . . Moonwort.

Forget me not . . . . Forget-me-not.

For once may pride befriend me . Tiger Fluwer.

Forsaken .

- Garden Anemone.

Forsaken . . . . Laburnum.

Fortitude : $\quad$ - . . Dipteracanthus Spectajili..

Fragrance . . . . Camphire.

Franliness . . . . . Osier.

Fraternal love . . . . . Woodbine.

Fraternal sympathy . . . . Syringa.

Freedom . . . . . . IVater Willow.

Freshness. . . . . . Damask Rose.

Friendship . . . . Acacia. Ivy.

Friendship, early : $:$. Bluce Perizuinkle.

Friendship, true . . . . Oak-leaved Geranium

Friendship, unchanging . . . Arbor Vitce.

Frivolity . • • • • . London Pricle.

Frugality . . . . . Chicory. Endive.

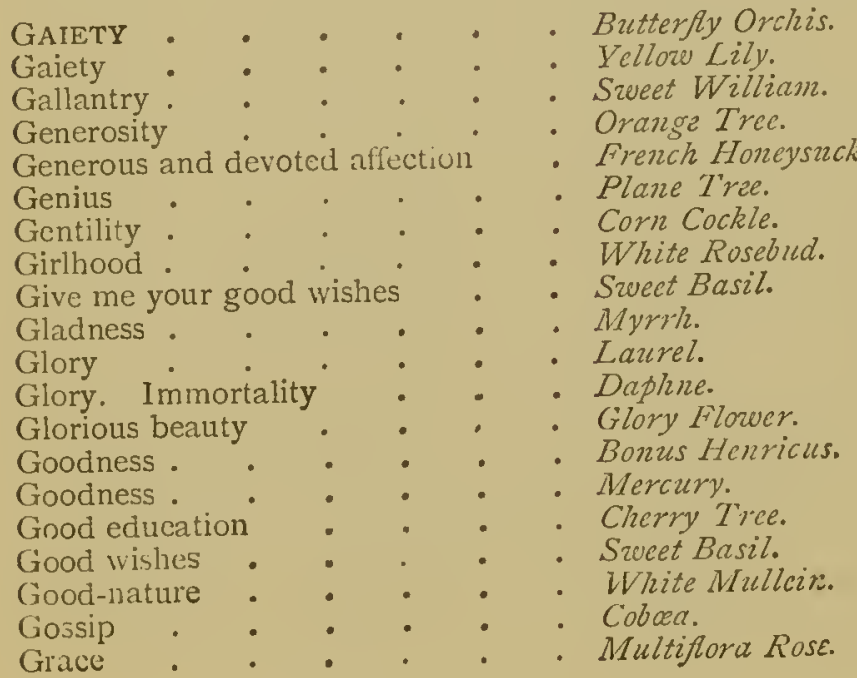


Graee and eleganee . • . . Yellow Fasmine.

Grandeur . . * . . Ash Tree.

Gratitude . • • . • . Small White Bellflower.

Grief . . . . . . Harebell.

Grief . . . . . . Marigold.

Happy love . . . . . Bridal Rose.

Hatred . • . . . . Basil

Haughtiness . . . . . Purple Larksfur.

Haughtiness . . . . . Tall Sunfower.

Health . . . . . Iceland Moss.

Hermitage . . . Milkwort.

Hidden worth :. Coriander.

High-bred . . . . Pentstemon Azureum.

Holy wishes . . . . . Plumbago Larpenta.

Honesty . . . . . . Honesty.

Hope . . . . . . Flowering Almond.

Hope . . . . . . Hawthom.

Hope . . . . . Snowdrop.

Hope in adversity . . . . Spruce Pine.

Hopeless love . . . . . Yellore Tulip.

Hopeless, not heartless . . . Love-lies-bleeding.

Horror . . . . . . Mandrake.

Horror , . . . . . Dragonswort.

Horror . . . . . Snakesfoot.

Hospitality . . . . . Oak Tree.

Humility. . . . . . Broom.

Humility . . . . . . Smaller Bindweed.

Humility . . . . . Field Lilac.

I AM too happy . . . . Cape Fasmine.

I am your eaptive . . . . Pcach Blossom.

I am worthy of you . . . . White Rose.

I change but in death . . . Bay Leaf.

I elaim at least your esteem . . Potentilla.

I dare not . . . . . Veronica Speciosa.

I deelare against you . . . Belvedere.

I deelare against you . . . Liquorice.

I declare war against you . . . Wild Tansy.

I die if negleeted . . . Laurestina.

I desire a return of affeetion . . Fonquil.

I feel my obligations . . . Lint.

I feel your kindness . . . . Flax.

I have lost all . . . . . Mouming Bride.

I live for thee . . . . . Cedar Leaf.

I love . . . . . Red Chrysanthemum.

I offer you my all . . . . Shepherd's Purse.

I offer you my forlune; or, I offer you pecuniary aid . . . Cizlicolaria.

I share your sentiments . . . Double China Aster

I share your sentiments . . . Garden Daisy.

I shall die to-morrow . . . Gum Cistus. 
I shall not survive you

I surmount difficultics

I watch over you

I weep for you.

I will think of it

I will think of it,

I wound to heal

If you love me, you will find it out

Idleness

Ill-naturc

Ill-natured beauty

Imagination

Immortality

Impatience

Impatient of absence

Impatient resolves

Importunity

Inconstancy

Incorruptible

Independence

Independence

Independence

Indifference

Indifference

Indifference

Indifference

Indiscretion

Indolence

Industry

Industry, Domestic

Ingeniousness

Ingenuity .

Ingenuous simplicity

Ingratitude

Innocence

Insincerity

Insinuation

Inspiration

Instability

Intellect

Intoxication

Irony

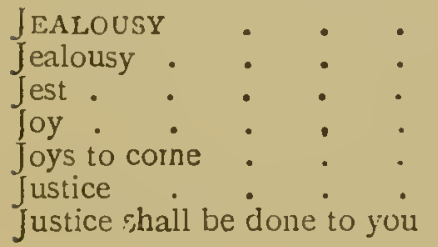

Black Mulberry.

Mistletoe.

Mountain Ash.

Purple Verbena.

Single Clina Aster.

Wild Daisy.

Eglantinc. Szuectbriur.

Maiden Blush Rose.

- Mesembryanthemum.

- Crab Blossom.

- Citron.

- Lupine.

- Globe Amaranti.

- Yellow Balsam.

- Corchorus.

- Red Balsam.

- Henbane.

- Burdock.

- Evening Primrose.

- Cedar of Lebanon.

- Commion Thistle.

- Wild Plum Tree.

- White Oak.

- Ever-flowering Candytuft.

- Mustard Seed.

- Pigeon Berry.

- Senvy.

- Split Reed.

- Mittraria Coccinea.

- Red Clover.

- Flax.

- White Pink.

- Pencilled Geranium.

- Mousc-eared Clickrueed.

- Crowifoot.

- Daisy.

- Foxglove.

- Great Bindweed.

- Angelica.

- Dahlia.

- Walnut.

- Vine.

- Sardony.

French Marigold.

- Yelluze Rose.

- Southernwood.

- Wood Sorrel.

- Lesser Celandine.

- Rudbeckia.

- Coltsfoot, or Sweet-scented Tus silage. 
KEEP your promise .

Kindness.

Knight-errantry

Petunia.

Scarlet Geraninm.

Helmet Flozver (Monkshood).

LAMENTATION

Lasting bcauty

Lasting pleasures

Let me go

Lcvity

Liberty

Life

Light-hearted ness

Lightness.

Live for me

Love

Love

Love, forsaken

Love, returned.

Love is dangerous

Love for all seasons.

Lustre

Luxury

Aspen Tree.

- Stock.

- Everlasting Pea.

- Butterfy Weei.

- Larkspur.

- Live Oak.

- Lucerne.

- Shamrock.

- Larkspur.

- Arbor Vitce.

- Myrtle.

- Rose.

- Creeping IVillox.

- Anbrosia.

- Carulina Rose.

- Furze.

- Aconite-leaved Crorufoot, or Fai" Maid of Finnct.

MAGNIFICENCE

Magnificent beauty

Majesty

Make haste

Malevolence

Marriage

Maternal affection

Maternal love.

Maternal tenderness .

Matrimony

Matronly grace

Mature charms

May you be happy

Meanness

Meekness

Melancholy

Melancholy

Melancholy

Mental beauty.

Mental beauty .

Message

Mildness

Mirth

Misanthropy

$M$ isant hropy

Modest beauty

Modest genius

Chestnut Tree.

- Magnolia.

- Calla Rethiopica.

- Crown Imperial.

- Dianthus.

- Lobelia.

- Ioy.

- Cinquefoil.

- Moss.

- Wood Sorrel.

- American Linden.

- Cattleya.

- Cattleya Pineli.

- Volkamenia.

- Cuscute.

- Birch.

- Autumnal Leaves.

- Dark Geranium.

- Dead Leaves.

- Clematis.

- Kennedia.

- Iris.

- Mallow.

- Saffion Crocus.

- Aconite (Wolfsbanej

- Fuller's Teazle.

Trillium Piclum.

- Creeping Cereus. 
Modesty . . . . . Violet.

Modesty and purity . $\quad$ - . . White Lily.

Momentary lappiness . . . Virginian Spiderwort.

Mourning . . . . Weeping Willow.

Music . . . . . Bundles of Reed with thein Panicles.

My best days are past . . . Colchicum, or Meadow Siffion. My regrets follow you to the grave . Asphodel.

NEATNESS . . . . . Broom.

Neglected beauty . . . . Throatwort.

Never ceasing remembrance . . Evicrlasting.

Never despair . - . * . Watcher by the IVayside.

No . . . . . . Snapdragon.

OLd age . . . . . Tree of Life.

Only deserve my love $\quad . \quad$. Rose Campion.

PAINFUL recollections . . . Flos Adonis.

Painting . . . . . Auricula.

Painting the lily . . . . Daphne Odora.

Passion . . . . . White Dittany.

Paternal error . . . . . Cardamine.

Patience. . . Dock. Ox-eye.

Patriotism . . . . American Elm.

Patriotism . . . . Nasturtium.

Heace . . . Olive.

Perfected loveliness . . . . White Cimellia Faponica.

Perfidy . . Common Laurel, in flower.

Pensive beauty. . . . Laburnum.

Perplexity

Persecution

Perseverance . $\quad . \quad . \quad$. Swamp Magnolia.

Persuasion . . Althea Frutex.

Persuasion . . . . Syrian Mallow.

Pertinacity . . . Clotbur.

Pity . . . . . Pine, also Andromeda.

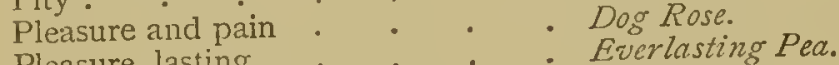

Pleasure, lasting * - * - Thite Periwinkle.

Pleasures of memory : $\quad$. $\quad$. Dahlia.

Pomp

Pepular favour.

Poverty

Power

Cistus, or Rock Rose.

- Evergreen Clematis.

Power . . . . Cress.

Pray for $\mathrm{m}$ s

Precaution

Prediction

Pretension

Pride

White Verbena.

Golden Rod.

Prophetic Marigold.

- Spiked Willow Herb.

Pride

- Hundred-leaved Rose.

- Amaryllis. 


\begin{tabular}{|c|c|c|c|c|c|c|}
\hline Privation & - & - & • & $=$ & - & - Indian Plum. \\
\hline Privation & - & - & a & . & - & - Myrobalan. \\
\hline Frofit ... & $\cdot$ & - & - & . & . & - Cabbage. \\
\hline Prohibitio & & - & - & - & - & - Privet. \\
\hline Prolifie & . & • & - & - & - & - Fig Tree. \\
\hline Promptises & & - & - & - & - & - Ten-rueek Stock. \\
\hline Prosperity & & - & - & • & . & - Beech Tree. \\
\hline Proteetion & & - & - & . & - & - Bearded Crepis. \\
\hline Prudence & & - & - & , & - & - Mountain Ash. \\
\hline Pure love & & $\cdot$ & $\dot{0}$ & - & * & . Single Red Pink. \\
\hline Pure and & arden & tov & & : & - & - Double Red Pink. \\
\hline Pure and & lovely & & - & - & - & - Ked Rosebud. \\
\hline Purity & - & - & - & . & • & - Star of Bethlehem. \\
\hline QUARREL & & $\cdot$ & - & - & - & - Broken Corn-straw. \\
\hline Quieksigh & tedne & & - & - & • & - Hawkwecd. \\
\hline READY-Ai & RMED & & • & - & - & - Gladioli. \\
\hline Reason & & - & - & - & - & - Goat's Rue. \\
\hline Recantatio & & - & - & - & - & - Lotus Leaf. \\
\hline Reeall & & - & - & - & - & - Silver-leaved Geranism \\
\hline Reconeilia & tion & - & - & - & - & - Filbert. \\
\hline Reeoneilia & tion & - & - & - & - & - Hazel. \\
\hline Refinemen & & - & - & - & - & - Gardenia. \\
\hline Refusal & & - & - & - & - & - Striped Camation. \\
\hline Regard & & - & - & - & - & - Daffodil. \\
\hline Regret & . & - & - & - & - & - Purple Verbena. \\
\hline Relief & & : & - & . & . & - Balm of Gileud. \\
\hline Relieve my & $y \operatorname{anx}$ & kiety & . & . & . & - Christmas Rose. \\
\hline Religious : & super: & rstition & & & - & - Aloe. \\
\hline Religious : & super & rstitio & n, or & Faith & & - Passion Flower. \\
\hline Religious & enthu & isiasin & & $\cdot$ & - & - Schinus. \\
\hline Remembra & ance & $\cdot$ & - & - & $\bullet$ & - Rosemary. \\
\hline Remorse & - & - & - & - & - & - Bramble. \\
\hline Remorse & $\dot{0}$ & - & - & - & - & - Raspberry. \\
\hline Rendezvou & & - & . & 。 & - & - Chickweed. \\
\hline Reserve & - & - & - & - & - & - Maple. \\
\hline Resistance & & & $\cdot$ & - & - & - Tremilla Nestoc. \\
\hline Resolved t & o be & notic & & - & - & - Siphocampylos. \\
\hline Restoratior & & - & - & - & . & - Persicaria. \\
\hline Retaliation & & $\therefore$ & - & - & - & - Scotch Thistle. \\
\hline Return of 1 & happi & iness & - & - & - & - Lily of the Valley. \\
\hline Revenge & $\cdot$ & - & - & & * & - Birdsfuot Trefoil. \\
\hline Reverie & $\cdot$. & $\therefore$ & $\cdot$ & - & - & - Flowering Fern. \\
\hline Reward of & meri & & - & - & - & - Bay Wreath. \\
\hline Reward of & virtu & & - & - & - & - Garland of Roser. \\
\hline Riehes & $\cdot$ & $\cdot$ & - & - & - & - Corn. \\
\hline Riches & - & • & - & - & - & - Bultercups. \\
\hline Rigour & - & - & - & - & - & - Lantanu. \\
\hline Rivalry & - & • & - & - & - & - Rocket. \\
\hline Rudeness & $\cdot$ & - & - & - & - & - Clotbur. \\
\hline
\end{tabular}




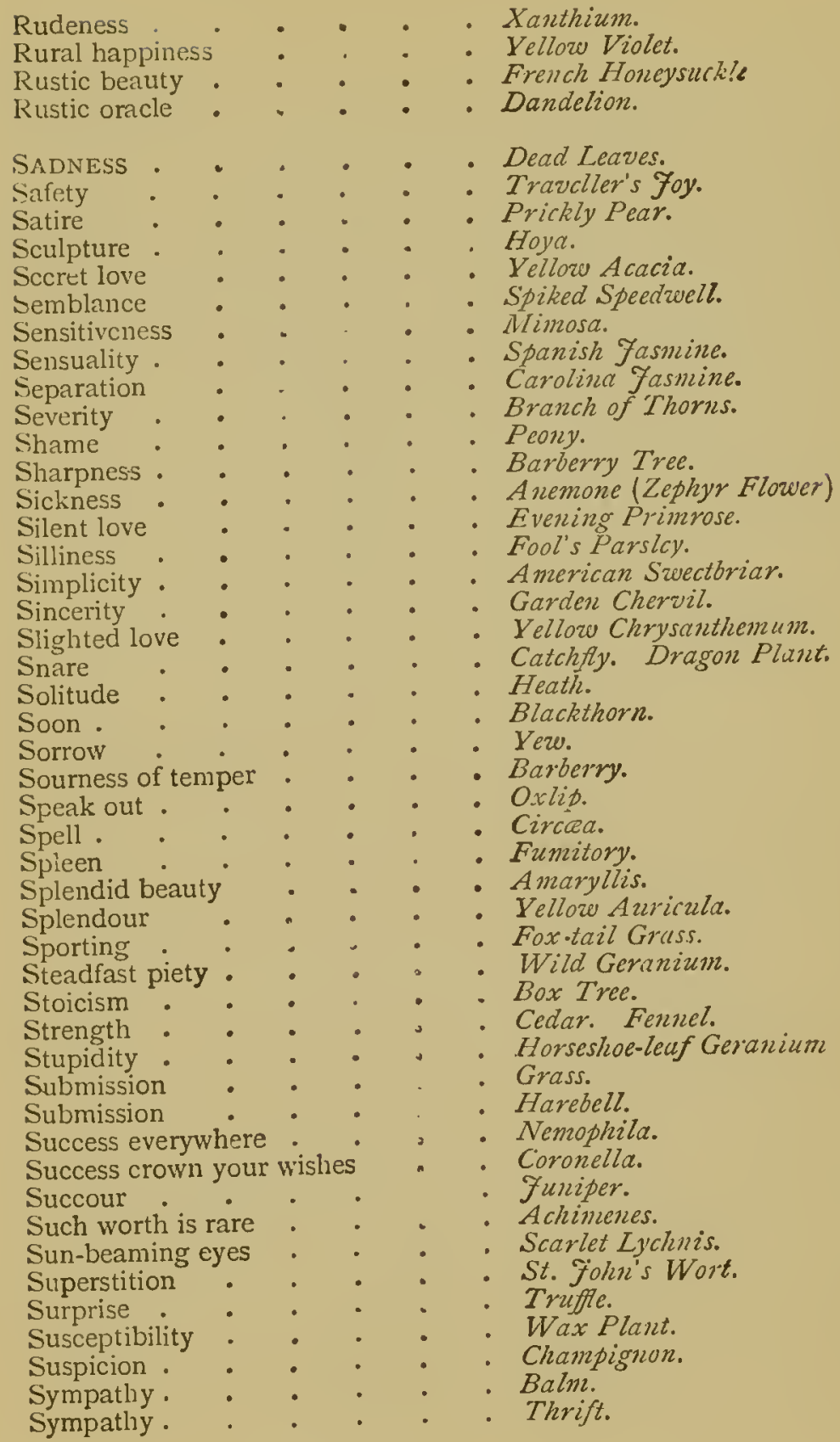




TAlENT :
Tardiness

The variety of your conversation delights me

Thee only do I love :

- Clarkia.

- Arbutus.

There is no unalloyed good - . Lapagenia Rosea.

Thoughts . . . . . Pansy.

Thoughts of absent friends . . Zinnia.

Thy frown will kill me . . . Currant.

Thy smile I aspire to : . . Daily Rose.

Ties $: \quad: \quad: \quad: \quad: \quad$ : Tendrils of Climbing Plants.

Timidity . . . . . Marvel of Peru.

Time

Tranquillity

Tranquillity

Tranquillize my anxiety

Transient beauty .

Transient impressions

rransport of joy

Treachery

True love .

True friendship

Truth

White Poplar.

- Mudwort.

- Stonecrop.

- Christmas Rose.

- Night-blooming Cereus.

- Withered White Rose.

- Cape fasmine.

- Bilberry.

- Forget-me-not.

- Oak-leaved Geranium.

- Bittersweet Nightshadc.

Truth

UNANIMITY

- White Chrysanthemum.

Unbelief

Unceasing remembrance

Unchanging friendship

Unconscious beauty .

Unexpected meeting

Unfortunate attachment

Unfortunate love

Union

Unity

Unite against a common foe

Unpatronized merit .

Phlox.

- Fudas Tree.

- American Cudased.

- Arbor Vitce.

- Burgundy Rose.

- Lemon Geranium.

- Mourning Bridc.

- Scabious.

- Whole Straw.

- White and Red Rose together

- Scarlet Verbena.

- Red Primrose.

Unrequited love : $: \quad$. Daffodil.

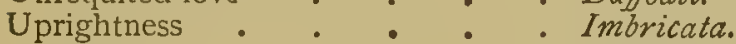

Uselessncss : : $: \quad$ : Meadowsweet.

Utility . . . . • . Grass. 


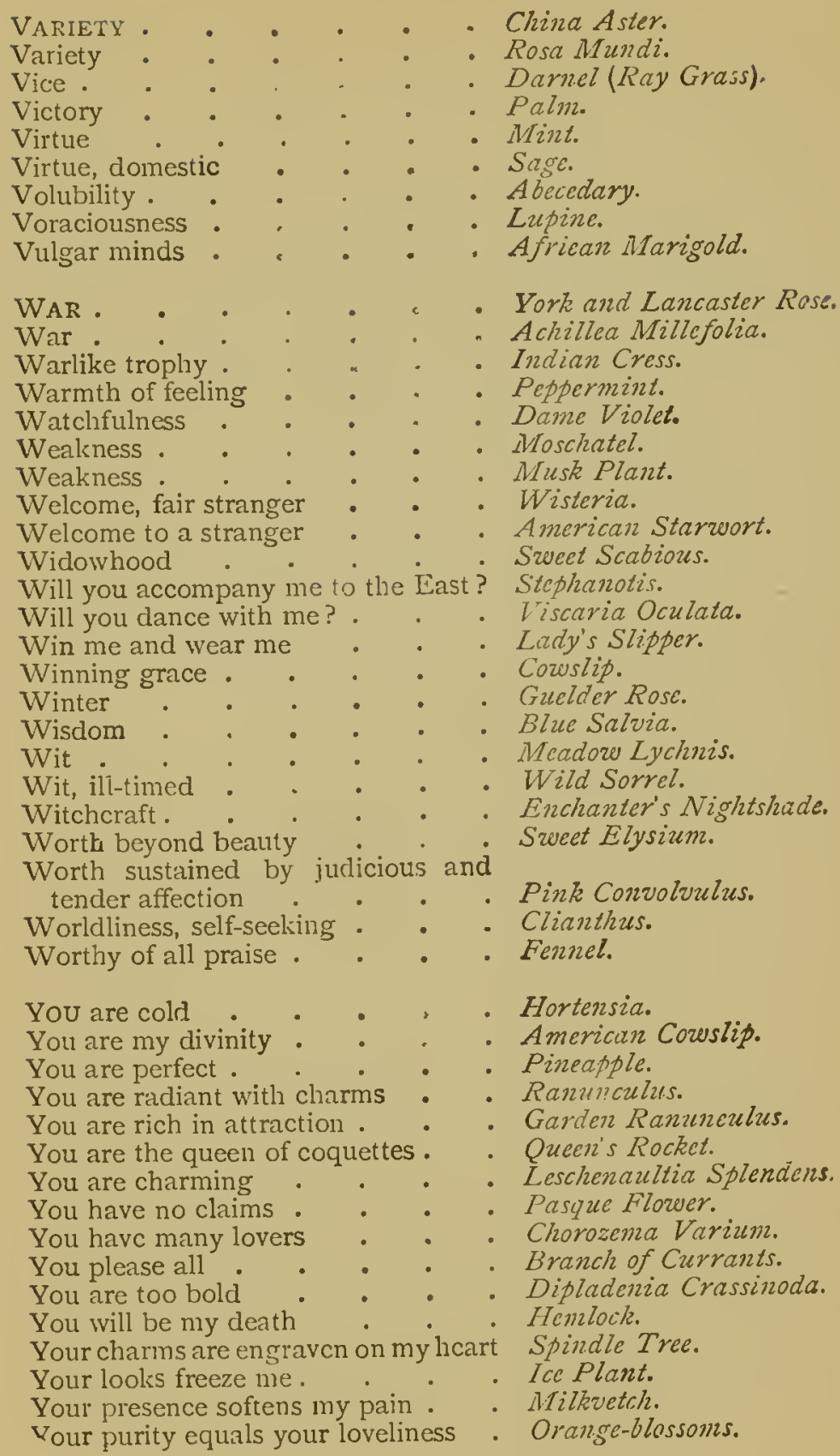


Your qualities, like your charms, are unequalled . . . . Peach.

Your qualities sutpass your charms . Mignonette.

Your temper is too hasty - . . Grammanthes Chloraflora.

Youthful beauty. . . . . Coreslip.

Youthful innocence : $:$ - White Lilac.

Youthful love . . . . . Red Catchfly.

Your whims are unbearable - . Monarda Amplexicaulis.

ZEALOUSNESS . • . . . Elder.

Zest . . . . . . Lemon. 




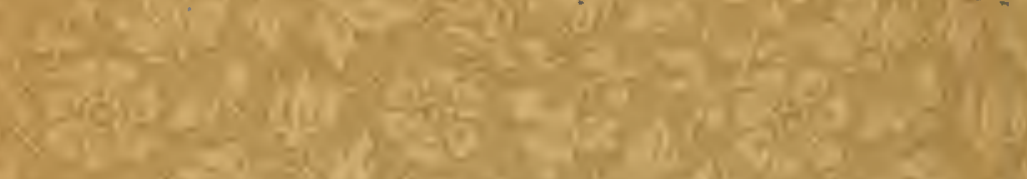

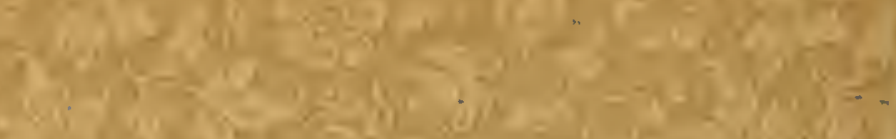

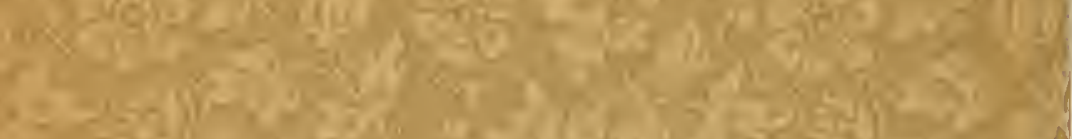

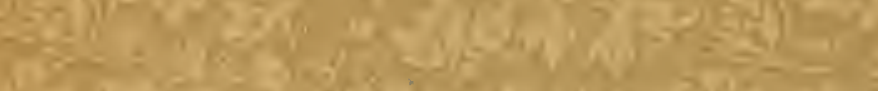

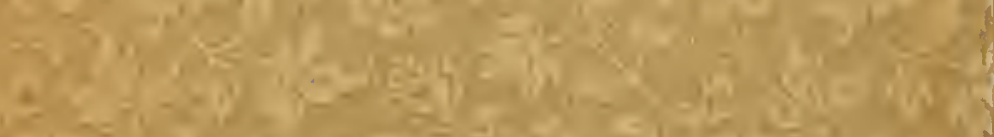

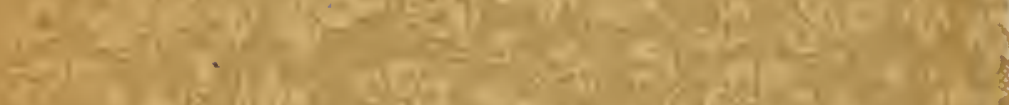

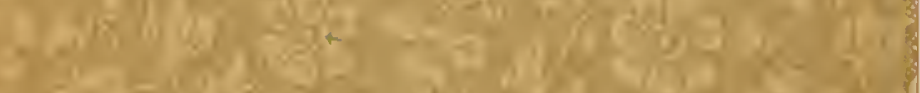

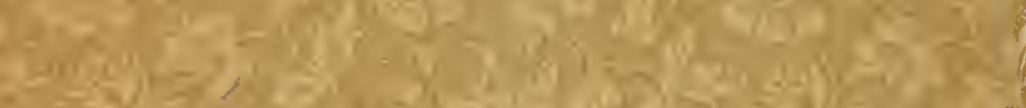

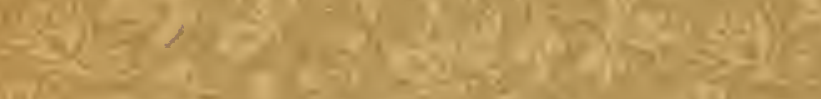

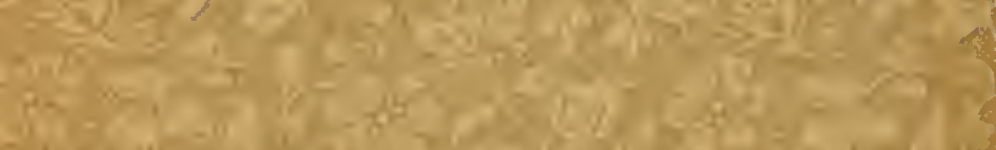

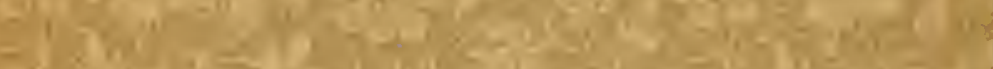

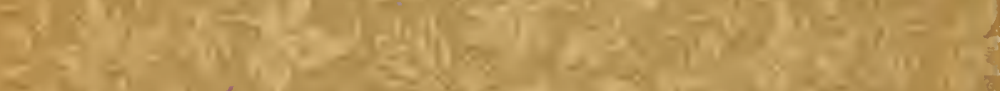

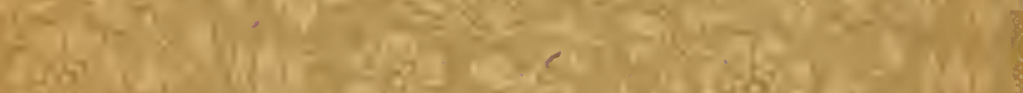

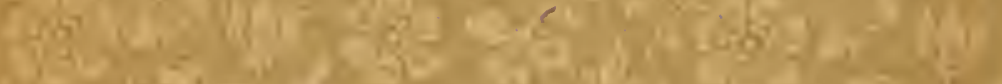

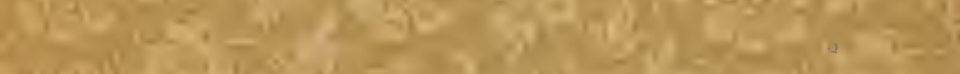

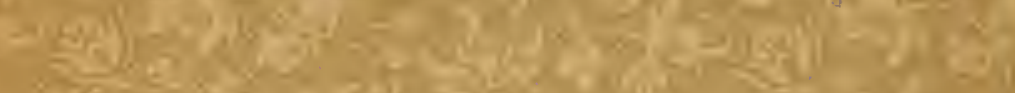

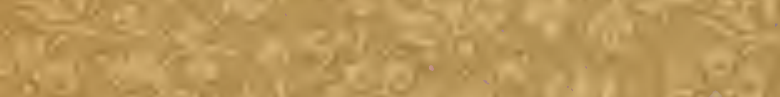

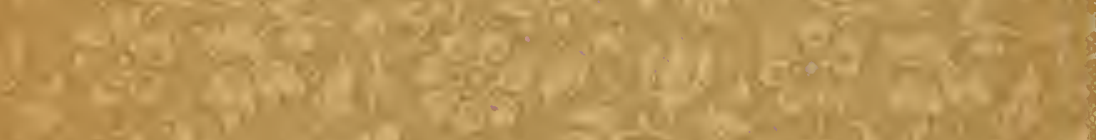

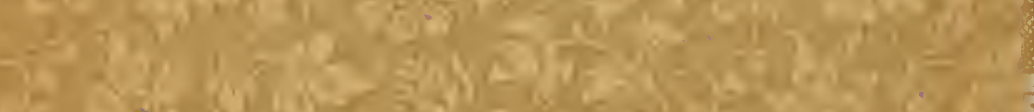

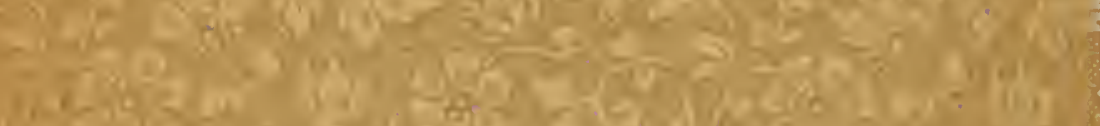

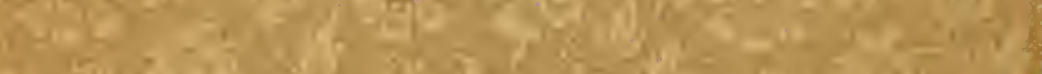

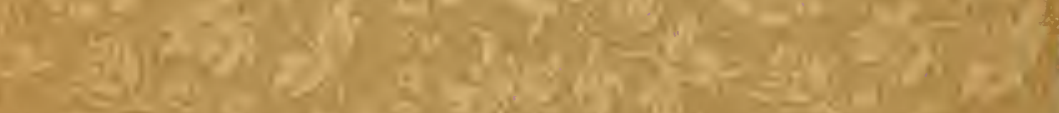

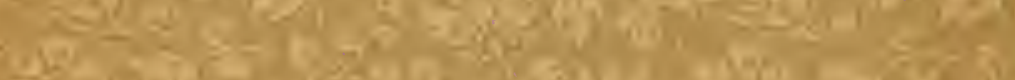

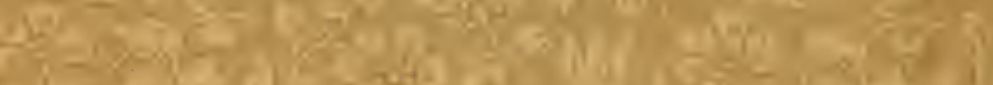

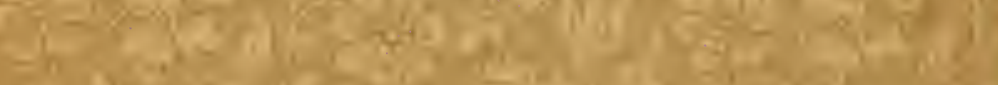

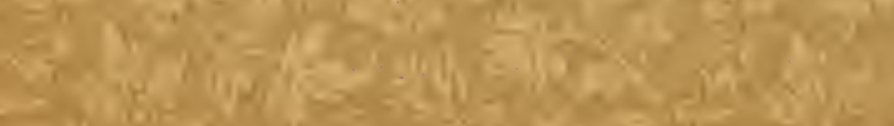



